ANA CLAUDIA PACHECO

\title{
Emprego de miniSTRs "non-CODIS" em amostras biológicas de DNA forense
}

Dissertação apresentada ao Programa de Pós-

Graduação Interunidades em Biotecnologia USP/Instituto Butantan/IPT, para obtenção do Título de Mestre em Biotecnologia. 


\section{ANA CLAUDIA PACHECO}

\section{Emprego de miniSTRs “non-CODIS" em amostras biológicas de DNA forense}

Dissertação apresentada ao Programa de PósGraduação Interunidades em Biotecnologia USP/Instituto Butantan/IPT, para obtenção do Título de Mestre em Biotecnologia.

Área de concentração: Biotecnologia

Orientador: Prof. Dr. Durvanei Augusto Maria 
DADOS DE CATALOGAÇÃO NA PUBLICAÇÃO (CIP)

Serviço de Biblioteca e Informação Biomédica do

Instituto de Ciências Biomédicas da Universidade de São Paulo

(c) reprodução total

Pacheco, Ana Claudia.

Emprego de miniSTRs "non-CODIS" em amostras biológicas de DNA forense / Ana Claudia Pacheco. -- São Paulo, 2010.

Orientador: Durvanei Augusto Maria.

Dissertação (Mestrado) - Universidade de São Paulo. Instituto de Ciências Biomédicas. Programa de Pós-Graduação Interunidades em Biotecnologia USP/IPT/Instituto Butantan. Área de concentração:

Biotecnologia. Linha de pesquisa: DNA forense.

Versão do título para o inglês: The use of "non-CODIS" miniSTRs in forensic DNA biological samples.

Descritores: 1. DNA 2. Forense 3. Identificação (humano) 4. Microssatélites I. Maria, Durvanei Augusto II. Universidade de São Paulo. Instituto de Ciências Biomédicas. Prgrama de Pós-Graduação Interunidades em Biotecnologia USP/IPT/Instituto Butantan. III. Título. 
Candidato(a):

Título da Dissertação:

Orientador(a):
Ana Claudia Pacheco.

Emprego de miniSTRs "non-CODIS" em amostras biológicas de DNA forense.

Durvanei Augusto Maria.

A Comissão Julgadora dos trabalhos de Defesa da Dissertação de Mestrado, em sessão pública realizada a ..........
( ) Aprovado(a)
( ) Reprovado(a)

Examinador(a): Assinatura:

Nome:

Instituição:

Examinador(a): Assinatura:

Nome:

Instituição:

Presidente: Assinatura:

Nome:

Instituição: 


\title{
ANEXO B - Parecer da Comissão de Ética
}

\author{
SECRETARIA DA SEGURANÇA PÚBLICA \\ SUPERINTENDÊNCIA DA POLÍCIA TÉCNICO-CIENTÍFICA \\ INSTITUTO DE CRIMINALISTICA \\ "Perito Criminal Dr.Octávio Eduardo de Brito Alvarenga" \\ CENTRO DE EXAMES, ANÁLISES E PESQUISAS - CEAP \\ NÚCLEO DE BIOLOGIA E BIOQUÍMICA - LABORATÓRIO DE DNA
}

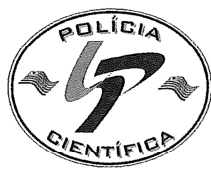

São Paulo, 20 de março de 2009.

Atesto para os devidos fins que o Núcleo de Biologia e Bioquímica do Instituto de Criminalística do Estado de São Paulo esteve de ciente e de acordo com o uso das amostras questionadas referentes aos casos recebidos em 2009 pela perita criminal Ana Claudia Pacheco, nas pesquisas do projeto entitulado "Emprego de miniSTRs "non-CODIS" em amostras biológicas de DNA forense", tendo como responsáveis o orientador Prof. Dr. Durvanei Augusto Maria e a própria mestranda Ana Claudia Pacheco.

Informo ainda que as amostras de indivíduos vivos foram fornecidas de espontânea vontade, com assinatura de Termo de Consentimento e comprometimento de Sigilo de sua identidade em todas as fases da pesquisa.

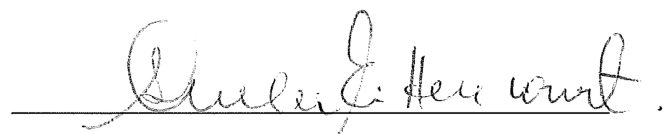

Dra. Eloísa A. Auler Bittencourt

Diretora do Núcleo de Biologia e Bioquimica do Instituto de Criminalística do Estado de São Paulo 
Aos meus pais, ao meu querido João e a todos meus familiares e amigos verdadeiros pelo incentivo à minha formação e dedicação.

Muito obrigada!!! 


\section{AGRADECIMENTOS}

Ao meu orientador, Prof. Dr. Durvanei Augusto Maria, meus sinceros agradecimentos por ter me dado esta oportunidade, por sua receptividade, seu auxílio em todos os momentos e sobretudo por compreender as dificuldades em se conciliar estudo e trabalho!

À Life Technologies - Applied Biosystems do Brasil, que forneceu o apoio financeiro a este trabalho, especialmente pelo incentivo inicial por parte da Dra. Gabriela Casemiro da Rocha Hirschfeld-Campolongo, a quem agradeço imensamente, além dos colegas Patrícia Barco, Weslley M. Tsutsumida e Paulo E. Raiman que me auxiliaram diversas vezes ao longo do período dos meus experimentos.

Ao Laboratório de DNA do Instituto de Criminalística da Superintendência da Polícia Técnico-Científica do Estado de São Paulo e ao Laboratório de Bioquímica e Biofísica do Instituto Butantan, que em colaboração propiciaram o desenvolvimento deste projeto.

À Dra. Eloísa A. Auler Bittencourt, perita criminal Diretora do Núcleo de Biologia e Bioquímica do Instituto de Criminalística do Estado de São Paulo, pelo apoio e estímulo incondicionais para realização da minha pós-graduação.

Ao Dr. Adilson Pereira, perito criminal Diretor do Centro de Exames, Análises e Pesquisas do Instituto de Criminalística do Estado de São Paulo, por sua dedicação para melhorar cada vez mais as condições de trabalho em nossos laboratórios.

Às peritas criminais colegas de trabalho no Laboratório de DNA do Instituto de Criminalística, Margaret Mitiko Inada Pereira, Maria Luiza A. P. O. e Sousa, Roberta C. da Rocha Hirschfeld Campolongo, Cristina Lekich, Débora Rose de Oliveira, Juliana Romera Mansilha Dias, Miriam L'Abbate e Norma Sueli Bonaccorso, por seu incentivo e auxílio nos momentos em que precisei, pelas trocas de horários, extrações, amplificações, eletroforeses, correções de laudos, etc. Às técnicas de laboratório Ellen Polleto Faccioli Castellón e Jeane Oliveira Santos; em especial à querida Ellen, que tanto me ajudou na execução dos meus casos. Aos diversos estagiários que estiveram no laboratório nestes últimos três anos e que também me auxiliaram neste período. 
À toda minha família e meus amigos, que sempre me apoiaram e me estimularam nos estudos. Ao João, pela paciência, compreensão e dedicação durante os todos esses anos que estamos juntos.

A todos os demais que de alguma forma contribuíram com o desenvolvimento deste trabalho e com a minha formação, meus mais sinceros agradecimentos. 


\section{RESUMO}

PACHECO, A. C. Emprego de miniSTRs "non-CODIS" em amostras biológicas de DNA forense. 2010. 134 f. Dissertação (Mestrado em Biotecnologia) - Instituto de Ciências Biomédicas, Universidade de São Paulo, São Paulo, 2010.

Nas últimas duas décadas a análise de DNA com a finalidade de identificação humana tem sido uma ferramenta importante no auxílio às investigações criminais. As técnicas baseadas no estudo de polimorfismos da molécula de DNA humana, os microssatélites (STR - short tandem repeats), estão bem estabelecidas como um processo seguro, com alto poder de discriminação e alta confiabilidade, sendo aceitas como prova legal em casos judiciais. Os materiais biológicos relacionados a eventos criminais encontram-se frequentemente degradados ou contaminados por agentes interferentes e, na expectativa de se reduzirem os problemas de sua amplificação através da reação de PCR, foram mais recentemente desenvolvidos ensaios baseados no uso dos miniSTRs que geram produtos de amplificação menores, oferecendo resultados mais consistentes e robustos. $\mathrm{Na}$ comunidade forense, principalmente nos Estados Unidos, um conjunto de treze marcadores STR vem sendo amplamente utilizado e a partir deles foram criados grandes bancos de dados de perfis genéticos, como é o caso do CODIS (Combined DNA Index System). Existem algumas ocasiões em que se torna necessário o estudo de outras regiões do DNA, favorecendo o uso dos STRs "non-CODIS". Neste trabalho foram analisados materiais relacionados a casos forenses criminais do Laboratório de DNA do Instituto de Criminalística do Estado de São Paulo, totalizando 80 amostras, sendo o DNA extraído de diferentes fontes como materiais cadavéricos, vestígios de crimes sexuais e de locais de crimes, dispostos nos mais variados tipos de suportes. As amostras foram extraídas segundo protocolos específicos para cada tipo de material biológico, quantificadas por PCR em tempo real, amplificadas pela técnica de PCR, no formato de duas reações do tipo triplex, amplificando simultaneamente os miniSTRs "non-CODIS" D10S1248, D14S1434 e D22S1045 ("non-CODIS" 01 - NCO01) e as regiões D1S1677, D2S441 e D4S2364 (“non-CODIS" 02 - NCO02). Os produtos de amplificação foram submetidos à eletroforese capilar com detecção da fluorescência emitida pelos fluoróforos utilizados para a marcação dos primers. Foram avaliados o grau de conservação das amostras e a qualidade dos perfis genéticos que puderam ser estabelecidos. Os resultados foram confrontados com os obtidos através das técnicas rotineiramente empregadas no laboratório, havendo concordância nas dificuldades relativas entre diferentes tipos de amostras quando comparado com as abordagens tradicionais. Como conclusões, foi possível confirmar a sensibilidade e robustez dos sistemas utilizados, bem como a real vantagem em se aumentar o número de regiões analisadas, principalmente em casos complexos, mas foram constatadas desvantagens em se realizar procedimentos do tipo "in-house", em comparação ao emprego de kits comerciais, dadas as necessidades maiores de manipulação dos reagentes, o que dificulta o estabelecimento e a avaliação dos parâmetros de controle de qualidade laboratorial. Considera-se ainda a necessidade de serem estabelecidos bancos de dados de frequências alélicas destes loci para a população brasileira, que possam ser incorporadas nos cálculos estatísticos necessários aos laudos periciais.

Palavras-chave: Microssatélites. STR. MiniSTR. D1S1677. D2S441. D4S2364. D10S1248. D14S1434. D22S1045. Identificação humana. DNA. Forense. 


\begin{abstract}
PACHECO, A. C. The use of "non-CODIS" miniSTRS in forensic DNA biological samples. 2010. 134 p. Master thesis (Biotechnology) - Instituto de Ciências Biomédicas, Universidade de São Paulo, São Paulo, 2010.

During the last two decades, DNA analysis with the purpose of human identification has been an important tool for criminal investigation. The techniques based on the study of polymorphisms of the human DNA molecule, the microsatellites (STR - short tandem repeats), are well established as safe processes, with a high power of discrimination, high reliability and are accepted as legal evidence in forensic casework. Due to the fact that criminal biological evidence are frequently degraded or contaminated by interferents and aiming to reduce the difficulties in its amplification through the PCR reaction, more recently were developed assays using the miniSTRs with smaller amplification products, offering more consistent and robust results. In the forensic community, mainly in the USA, a set of thirteen STR markers have been widely used and based on them large genetic profiles databases were created, as CODIS (Combined DNA Index System). There are occasions in which the study of other regions of the DNA molecule is necessary, increasing the loci panel, favoring the use of "non-CODIS" STRs. In this work, forensic casework material from the DNA Laboratory of the Criminalistics Institute of the State of São Paulo was analyzed, an amount of 80 samples, and DNA was extracted from different sources as corpse material, sexual assault and crime scene evidence, in various types of surfaces, in order to evaluate the use of the "non-CODIS" miniSTRs D1S1677, D2S441, D4S2364, D10S1248, D14S1434 and D22S1045. The samples were extracted according to specific protocols for each biological material, quantified using real-time PCR, amplified by the PCR technique, in two triplex reactions, simultaneously amplifying the loci D10S1248, D14S1434 and D22S1045 ("nonCODIS" 01 - NCO01) and the loci D1S1677, D2S441 and D4S2364 ("non-CODIS" 02 NCO02). The amplification products were submitted to capillary electrophoresis with detection of the fluorescence emitted by the fluorophores used for primer labeling. The sample preservation and the quality of the genetic profiles obtained were evaluated. The results were compared to the previous obtained with the routine techniques employed in the laboratory and there was concordance in the relative difficulties according to different types of samples, in comparison to traditional approaches. As conclusions, the sensibility and robustness of the systems employed were confirmed, as the real advantages in increasing the number of loci studied, mainly in the complex cases analyzed. Comparing to the use of commercially available kits, "in-house" procedures were considered a disadvantage, due to major reagent manipulation, which makes more difficult the establishment and evaluation of the laboratory quality control assessment. Allele frequencies databases for these loci, for the Brazilian population are still necessary in order to be used in the statistical calculations of the forensic reports.
\end{abstract}

Key-words: Microsatelites. STR. MiniSTR. D1S1677. D2S441. D4S2364. D10S1248. D14S1434. D22S1045. Human identification. DNA. Forensic. 


\section{LISTA DE ILUSTRAÇÕES}

Figura 1 - $\quad$ Representação de sequência de bases nitrogenadas do DNA, apresentando 9 repetições consecutivas do bloco CTGA (alelo 9), exemplificando um microssatélite (STR). 33

Figura 2 - $\quad$ Representação ilustrativa da diferença da posição dos primers em relação ao início da sequência repetitiva no caso de STRs e

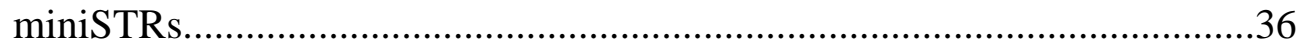

Figura 3 - $\quad$ A - Localização do microssatélite D1S1677 em representação esquemática do cromossomo 1 humano. B - Número da sequência de referência, nome do arquivo e sequência da região polimórfica encontrados no banco de dados GenBank, disponibilizado na página da Internet "NCBI: Entrez Nucleotide" (GENBANK, 2010). Encontram-se destacadas em amarelo a posição de ligação dos primers utilizados neste estudo e sublinhada sequência polimórfica .45

Figura 4 - $\quad$ A - Localização do microssatélite D2S441 em representação esquemática do cromossomo 2 humano. B - Número da sequência de referência, nome do arquivo e sequência da região polimórfica encontrados no banco de dados GenBank, disponibilizado na página da Internet "NCBI: Entrez Nucleotide" (GENBANK, 2010). Encontram-se destacadas em amarelo a posição de ligação dos primers utilizados neste estudo e sublinhada sequência polimórfica. .46

Figura 5 - $\quad$ A - Localização do microssatélite D4S2364 em representação esquemática do cromossomo 4 humano. B - Número da sequência de referência, nome do arquivo e sequência da região polimórfica encontrados no banco de dados GenBank, disponibilizado na página da Internet "NCBI: Entrez Nucleotide" (GENBANK, 2010). Encontram-se destacadas em amarelo a posição de ligação dos primers utilizados neste estudo e sublinhada sequência polimórfica......

Figura 6 - A - Localização do microssatélite D10S1248 em representação esquemática do cromossomo 10 humano. B - Número da sequência de referência, nome do arquivo e sequência da região polimórfica encontrados no banco de dados GenBank, disponibilizado na página da Internet "NCBI: Entrez Nucleotide" (GENBANK, 2010). Encontram-se destacadas em amarelo a posição de ligação dos primers utilizados neste estudo e sublinhada sequência polimórfica. .48

Figura 7 - $\quad$ A - Localização do microssatélite D14S1434 em representação esquemática do cromossomo 14 humano. B - Número da sequência de referência, nome do arquivo e sequência da região polimórfica encontrados no banco de dados GenBank, disponibilizado na página da Internet "NCBI: Entrez Nucleotide" (GENBANK, 2010). Encontram-se destacadas em amarelo a posição de ligação dos primers utilizados neste estudo e sublinhada sequência polimórfica 
Figura 8 - A - Localização do microssatélite D22S1045 em representação esquemática do cromossomo 22 humano. B - Número da sequência de referência, nome do arquivo e sequência da região polimórfica encontrados no banco de dados GenBank, disponibilizado na página da Internet "NCBI: Entrez Nucleotide" (GENBANK, 2010). Encontram-se destacadas em amarelo a posição de ligação dos primers utilizados neste estudo e sublinhada sequência polimórfica..... .50

Figura 9 - Eletroferogramas obtidos após a amplificação dos DNA controles 9947A, 9948, ABI 007 e K562 com o par de primers para o locus D1S1677, com o fluoróforo NED. Eixo x, tamanho em pares de bases; eixo y, unidade relativa de fluorescência (relative fluorescence unit - RFU).

Figura 10 - Eletroferogramas obtidos após a amplificação dos DNA controles 9947A, 9948, ABI 007 e K562 com o par de primers para o locus D2S441, com o fluoróforo VIC. Eixo x, tamanho em pares de bases; eixo y, unidade relativa de fluorescência (relative fluorescence unit - RFU)

Figura 11 - Eletroferogramas obtidos após a amplificação dos DNA controles 9947A, 9948, ABI 007 e K562 com o par de primers para o locus D4S2364, com o fluoróforo FAM. Eixo x, tamanho em pares de bases; eixo y, unidade relativa de fluorescência (relative fluorescence unit - RFU) .70

Figura 12 - Eletroferogramas obtidos após a amplificação dos DNA controles 9947A, 9948, ABI 007 e K562 com o par de primers para o locus D10S1248, com o fluoróforo FAM. Eixo x, tamanho em pares de bases; eixo y, unidade relativa de fluorescência (relative fluorescence unit - RFU) .70

Figura 13 - Eletroferogramas obtidos após a amplificação dos DNA controles 9947A, 9948, ABI 007 e K562 com o par de primers para o locus D14S1434, com o fluoróforo VIC. Eixo x, tamanho em pares de bases; eixo y, unidade relativa de fluorescência (relative fluorescence unit - RFU). Destacados em vermelho estão os picos inespecíficos/artefatos obtidos durante a validação deste locus. .71

Figura 14 - Eletroferogramas obtidos após a amplificação dos DNA controles 9947A, 9948, ABI 007 e K562 com o par de primers para o locus D22S1045, com o fluoróforo NED. Eixo x, tamanho em pares de bases; eixo y, unidade relativa de fluorescência (relative fluorescence unit - RFU) .71

Figura 15 - Eletroferogramas obtidos após a amplificação dos DNA controles 9947A, 9948, ABI 007 e K562 com os três pares de primers simultaneamente para o multiplex NC01 (loci D10S1248, D14S1434 e D22S1045), marcados, respectivamente, com os fluoróforos FAM, VIC e NED. Eixo x, tamanho em pares de bases; eixo y, unidade relativa de fluorescência (relative fluorescence unit - RFU). Destacados em vermelho estão os picos inespecíficos/artefatos obtidos durante a validação deste multiplex...............72

Figura 16 - Eletroferogramas obtidos após a amplificação dos DNA controles 9947A, 9948, ABI 007 e K562 com os três pares de primers simultaneamente para o 
multiplex NC01 (loci D10S1248, D14S1434 e D22S1045), marcados, respectivamente, com os fluoróforos FAM, VIC e NED e utilizando-se o QIAGEN $^{\circledR}$ Multiplex PCR Kit (QIAGEN). Eixo x, tamanho em pares de bases; eixo y, unidade relativa de fluorescência (relative fluorescence unit RFU). Circulados em vermelho estão os picos inespecíficos/artefatos obtidos durante a validação deste multiplex e as setas indicam a presença de dye blobs (artefatos do fluoróforo). .73

Figura 17 - Eletroferogramas obtidos após a amplificação dos DNA controles 9947A, 9948, ABI 007 e K562 com os três pares de primers simultaneamente para o multiplex NC02 (loci D1S1677, D2S441 e D4S2364), marcados, respectivamente, com os fluoróforos NED, VIC e FAM. Eixo x, tamanho em pares de bases; eixo $\mathrm{y}$, unidade relativa de fluorescência (relative fluorescence unit - RFU).........................................................................74

Figura 18 - Descrição do material, ilustração fotográfica e eletroferogramas obtidos após a amplificação das amostras 03-Osso fêmur e 06-Ossada de recém-nascido para os multiplex NC01 (loci D10S1248, D14S1434 e D22S1045) e NC02 (loci D4S2364, D2S441e D1S1677). Em azul, verde e preto, primers marcados, respectivamente, com os fluoróforos FAM, VIC e NED. Nos eletroferogramas, eixo $\mathrm{x}$, tamanho em pares de bases; eixo $\mathrm{y}$, unidade relativa de fluorescência (relative fluorescence unit - RFU) .79

Figura 19 - Descrição do material, ilustração fotográfica e eletroferogramas obtidos após a amplificação das amostras 14-Osso úmero e 19-Osso fêmur para os multiplex NC01 (loci D10S1248, D14S1434 e D22S1045) e NC02 (loci D4S2364, D2S441e D1S1677). Em azul, verde e preto, primers marcados, respectivamente, com os fluoróforos FAM, VIC e NED. Nos eletroferogramas, eixo $\mathrm{x}$, tamanho em pares de bases; eixo $\mathrm{y}$, unidade relativa de fluorescência (relative fluorescence unit - RFU). .80

Figura 20 - Descrição do material, ilustração fotográfica e eletroferogramas obtidos após a amplificação das amostras 25-Conteúdo uterino em caso de aborto e 28Espátula de madeira com secreção vaginal para os multiplex NC01 (loci D10S1248, D14S1434 e D22S1045) e NC02 (loci D4S2364, D2S441e D1S1677). Em azul, verde e preto, primers marcados, respectivamente, com os fluoróforos FAM, VIC e NED. Nos eletroferogramas, eixo x, tamanho em pares de bases; eixo y, unidade relativa de fluorescência (relative fluorescence unit - RFU). 83

Figura 21 - Descrição do material, ilustração fotográfica e eletroferogramas obtidos após a amplificação das amostras 31-B-Sondas uretrais e 32-B-Cueca 2 para os multiplex NC01 (loci D10S1248, D14S1434 e D22S1045) e NC02 (loci D4S2364, D2S441e D1S1677). Em azul, verde e preto, primers marcados, respectivamente, com os fluoróforos FAM, VIC e NED. Nos eletroferogramas, eixo $\mathrm{x}$, tamanho em pares de bases; eixo $\mathrm{y}$, unidade relativa de fluorescência (relative fluorescence unit - RFU)........................84

Figura 22 - Descrição do material, ilustração fotográfica e eletroferogramas obtidos após a amplificação das amostras 38-A-Material subungueal e 41-A-Camiseta com manchas de sangue para os multiplex NC01 (loci D10S1248, D14S1434 
e D22S1045) e NC02 (loci D4S2364, D2S441e D1S1677). Em azul, verde e preto, primers marcados, respectivamente, com os fluoróforos FAM, VIC e NED. Nos eletroferogramas, eixo x, tamanho em pares de bases; eixo y, unidade relativa de fluorescência (relative fluorescence unit - RFU)...........87

Figura 23 - Descrição do material, ilustração fotográfica e eletroferogramas obtidos após a amplificação das amostras 44-A-Estofamento de veículo e 52- Bituca de cigarro para os multiplex NC01 (loci D10S1248, D14S1434 e D22S1045) e NC02 (loci D4S2364, D2S441e D1S1677). Em azul, verde e preto, primers marcados, respectivamente, com os fluoróforos FAM, VIC e NED. Nos eletroferogramas, eixo $\mathrm{x}$, tamanho em pares de bases; eixo y, unidade relativa de fluorescência (relative fluorescence unit - RFU) .88

Figura 24 - Descrição do material, ilustração fotográfica, eletroferogramas e alelos obtidos após a amplificação das amostras 24-A-Osso fêmur de feto e 24-BSangue do suposto pai para os multiplex NC01 (loci D10S1248, D14S1434 e D22S1045) e NC02 (loci D4S2364, D2S441e D1S1677). Em azul, verde e preto, primers marcados, respectivamente, com os fluoróforos FAM, VIC e NED. Nos eletroferogramas, eixo $\mathrm{x}$, tamanho em pares de bases; eixo y, unidade relativa de fluorescência (relative fluorescence unit - RFU). Destacados em vermelho, alelos 8 observados fora do bin no locus D2S441, em ambas as amostras. .91

Figura 25 - Descrição do material, eletroferogramas e alelos obtidos após a amplificação das amostras 34-A-Sangue da mãe-vítima, 34-B-Sangue da criança e 34-CSangue do suposto pai para os multiplex NC01 (loci D10S1248, D14S1434 e D22S1045) e NC02 (loci D4S2364, D2S441e D1S1677). Em azul, verde e preto, primers marcados, respectivamente, com os fluoróforos FAM, VIC e NED. Nos eletroferogramas, eixo x, tamanho em pares de bases; eixo y, unidade relativa de fluorescência (relative fluorescence unit - RFU). 92

Figura 26 - Descrição do material, eletroferogramas e alelos obtidos após a amplificação das amostras 51-B-Sangue da suposta mãe, 51-A-Bermuda com manchas de sangue e 51-C-Sangue do suposto pai para os multiplex NC01 (loci D10S1248, D14S1434 e D22S1045) e NC02 (loci D4S2364, D2S441e D1S1677). Em azul, verde e preto, primers marcados, respectivamente, com os fluoróforos FAM, VIC e NED. Nos eletroferogramas, eixo x, tamanho em pares de bases; eixo y, unidade relativa de fluorescência (relative fluorescence unit - RFU). temp.ambiente, temperatura ambiente. .94

Figura 27 - Descrição do material, ilustração fotográfica, eletroferogramas e alelos obtidos após a amplificação das amostras 43-A-Material subungueal do cadáver 1, 43-B-Sangue do cadáver 1, 43-C-Sangue do cadáver 2, 46-ABrinco com manchas de sangue, 46-B-Bojo de sutiã com manchas de sangue e 46-C-Cueca com manchas de sêmen para os multiplex NC01 (loci D10S1248, D14S1434 e D22S1045) e NC02 (loci D4S2364, D2S441e D1S1677). Em azul, verde e preto, primers marcados, respectivamente, com os fluoróforos FAM, VIC e NED. Nos eletroferogramas, eixo x, tamanho em pares de bases; eixo $\mathrm{y}$, unidade relativa de fluorescência (relative fluorescence unit - RFU). 


\section{LISTA DE TABELAS}

Tabela 1 - Casos envolvendo Identificação de Cadáveres.............................................55

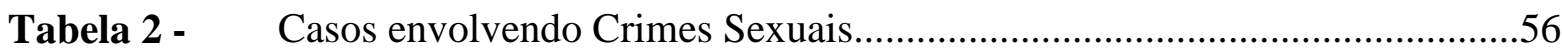

Tabela 3 - Casos envolvendo análise de vestígios biológicos oriundos de locais de

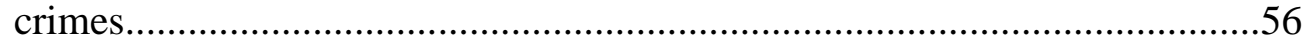

Tabela 4 - $\quad$ Identificação dos materiais e respectivo método de extração de DNA...........58

Tabela 5 - Loci polimórficos, sequências dos primers, fluoróforos, distância do oligonucleotídeo até o início do polimorfismo e concentração dos primers utilizada na reação de PCR (modificado de COBLE; BUTLER, 2005)

Tabela 6 - Componentes, concentrações e programação das reações de PCR utilizadas na etapa de validação dos primers.

Tabela 7 - Componentes, concentrações e programação das reações de PCR utilizadas na reação multiplex $\mathrm{NC} 01$ .64

Tabela 8 - Componentes, concentrações e programação das reações de PCR utilizadas na reação multiplex $\mathrm{NC} 02$

Tabela 9 - Loci polimórficos, alelos mais comuns e tamanhos esperados em pares de bases com base nos alelos dos controles de DNA utilizados, após ajustes no software de análise. .68

Tabela 10 - Loci polimórficos, controles de DNA e respectivos alelos esperados e obtidos durante as padronizações das reações individuais dos primers e no formato multiplex (modificado de Coble e Butler (2005). .75

Tabela 11 - Quantificação de DNA das amostras referentes aos casos de Identificação de Cadáveres. .75

Tabela 12 - Quantificação de DNA das amostras referentes aos casos de Crimes Sexuais. .76

Tabela 13 - Quantificação de DNA das amostras referentes aos casos de análise de vestígios biológicos oriundos de locais de crimes. 77

Tabela 14 - Alelos obtidos nos microssatélites para as amostras referentes aos casos de Identificação de Cadáveres, após as reações de amplificação multiplex NC01 e $\mathrm{NC} 02$.

Tabela 15 - Alelos obtidos nos microssatélites para as amostras referentes aos casos de Crimes Sexuais, após as reações de amplificação multiplex NC01 e $\mathrm{NC} 02$ 
Tabela 16 - Alelos obtidos nos microssatélites para as amostras dos vestígios biológicos provenientes de locais de crimes, após as reações de amplificação multiplex $\mathrm{NC} 01$ e $\mathrm{NC} 02$. 


\begin{tabular}{ll} 
9947A & DNA controle \\
9948 & DNA controle \\
$\boldsymbol{\mu}$ g & Micrograma \\
$\boldsymbol{\mu} \mathbf{L}$ & Microlitro \\
$\mathbf{0}$ C & Grau Celsius \\
A & Adenina \\
ABI 007 & DNA controle \\
ABNT & Associação Brasileira de Normas Técnicas \\
ABO & Sistema sanguíneo ABO \\
BO & Boletim de ocorrência \\
b22S1045 & Polimorfismo microssatélite \\
D10S1248 & Polimorfismo microssatélite \\
BSA & Base pair \\
C2S441 & Polimorfismo microssatélite \\
C & Plbumina bovina \\
CA & Citosina \\
\hline CEAP & California \\
\hline Centro de Exames Análises e Pesquisas
\end{tabular}




\begin{tabular}{|c|c|}
\hline DAB & DNA Advisory Board \\
\hline DNA & Ácido Desoxirribonucleico \\
\hline dNTPs & Desoxinucleotídeos trifosfato \\
\hline DTT & Ditiotreitol \\
\hline EDNAP & European DNA Profiling Group \\
\hline EDTA & Ácido Etilenodiaminotetracético \\
\hline ENFSI & European Network of Forensic Science Institutes \\
\hline EUA & Estados Unidos da América \\
\hline FAM & Fluoróforo FAM ${ }^{\mathrm{TM}}$ \\
\hline FE & Fração Espermatozoide \\
\hline FBI & Federal Bureau of Investigation \\
\hline FNE & Fração Não-Espermatozoide \\
\hline g & Grama \\
\hline $\mathbf{G}$ & Guanina \\
\hline GEP-ISFG & Grupo Español y Portugues de la International Society of Forensic Genetics \\
\hline GITAD & Grupo Iberoamericano de Trabajo en Análisis de DNA \\
\hline $\mathbf{h}$ & Hora \\
\hline HLA & Antígenos Leucocitários de Histocompatibilidade \\
\hline IC & Instituto de Criminalística \\
\hline IML & Instituto Médico Legal \\
\hline INTERPOL & International Criminal Police Organization \\
\hline IP & Índice de paternidade \\
\hline IP & Inquérito policial \\
\hline IPC & Índice de paternidade cumulativo \\
\hline ISFG & International Society of Forensic Genetics \\
\hline
\end{tabular}




\begin{tabular}{|c|c|}
\hline K562 & DNA controle - leucemia mielocítica humana \\
\hline $\mathbf{L C N}$ & Low copy number \\
\hline LR & Likelihood ratio \\
\hline $\mathbf{M}$ & Molar \\
\hline mg & Miligrama \\
\hline $\min$ & Minuto \\
\hline $\mathbf{m L}$ & Mililitro \\
\hline $\mathbf{m M}$ & Micromolar \\
\hline $\mathbf{M N}$ & Sistema sanguíneo MN \\
\hline NC01 & Non-CODIS 01 \\
\hline $\mathrm{NC02}$ & Non-CODIS 02 \\
\hline NED & Fluoróforo NED ${ }^{\mathrm{TM}}$ \\
\hline ng & Nanogramas \\
\hline NIJ & National Institute of Justice \\
\hline $\mathbf{n m}$ & Nanômetros \\
\hline PCR & Reação em cadeia da polimerase \\
\hline pg & Picogramas \\
\hline pmol & Picomol \\
\hline $\mathbf{P P}$ & Probabilidade de paternidade \\
\hline qsp & Quantidade suficiente para \\
\hline RFLP & Restriction fragment length polymorphism \\
\hline RFU & Relative fluorescence unit \\
\hline $\mathbf{R h}$ & Sistema sanguíneo $\mathrm{Rh}$ \\
\hline rpm & Rotações por minuto \\
\hline RPPH1 & Ribonuclease P RNA component H1 \\
\hline
\end{tabular}


seg Segundo

SNP Single nucleotide polymorphism

SP

São Paulo

SRY Sex-determining region Y

SSP Secretaria de Segurança Pública

STR Short Tandem Repeat

STRBase $\quad$ Short Tandem Repeat DNA Internet Database

SWGDAM Scientific Working Group on DNA Analysis Methods

T Timina

TE Tampão Tris-EDTA

U Unidades

USP Universidade de São Paulo

VIC Fluoróforo VIC

VNTR Variable Number of Tandem Repeat

WI Wisconsin 


\section{SUMÁRIO}

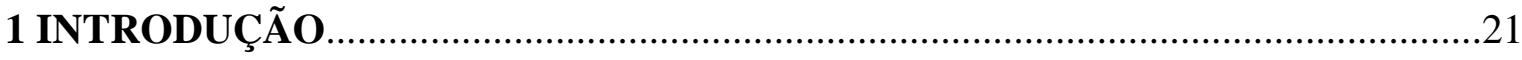

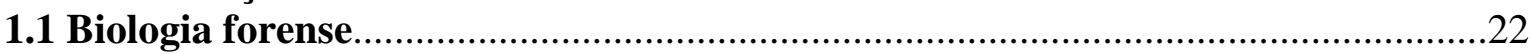

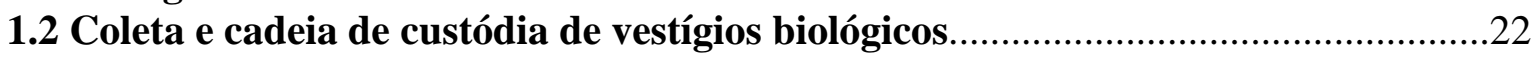

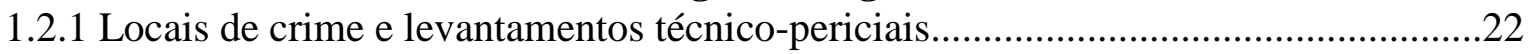

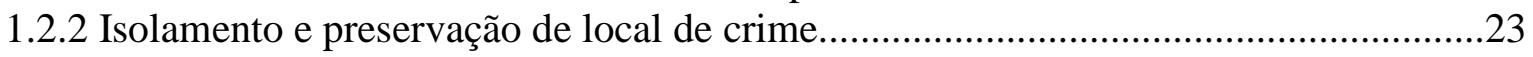

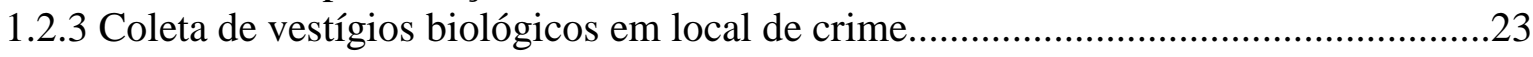

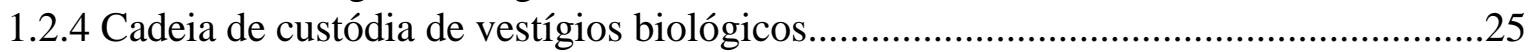

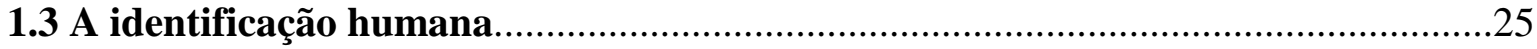

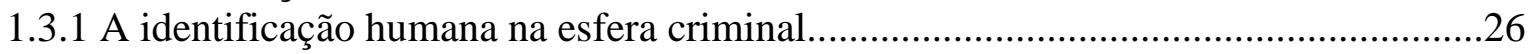

1.3.2 Testes de constatação de vestígios biológicos humanos............................................27

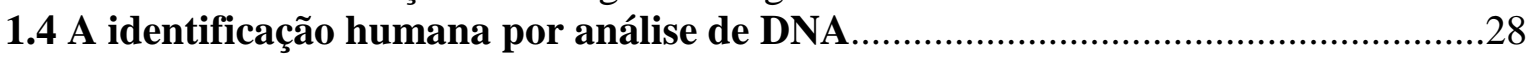

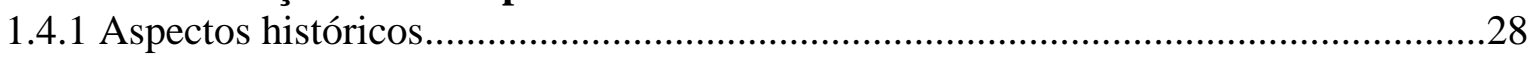

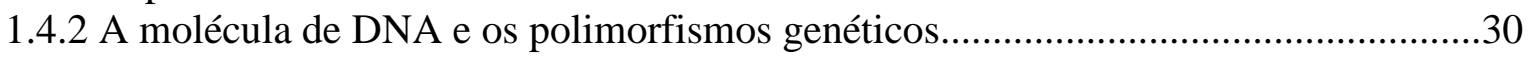

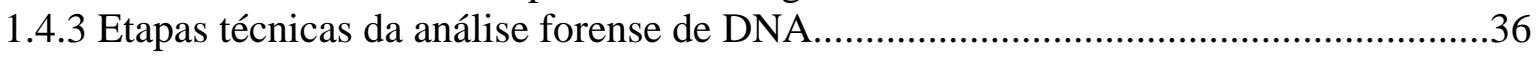

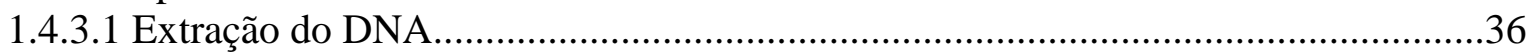

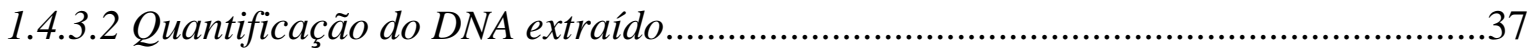

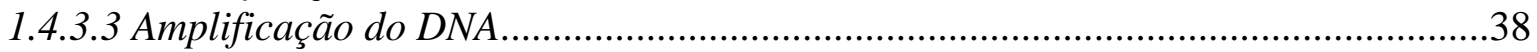

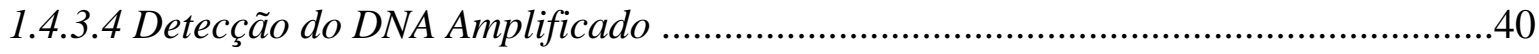

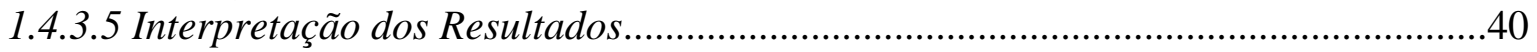

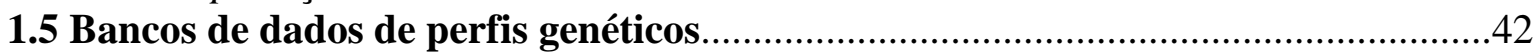

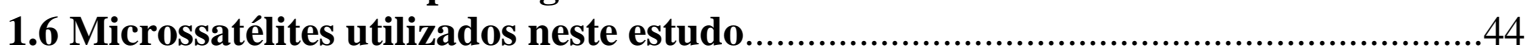

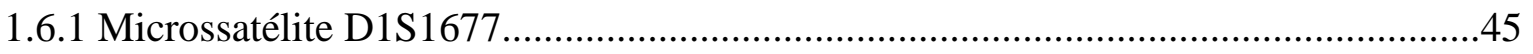

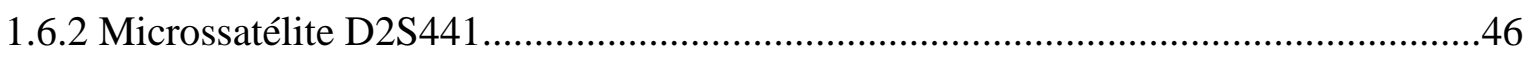

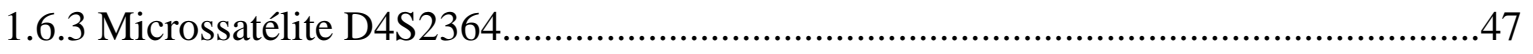

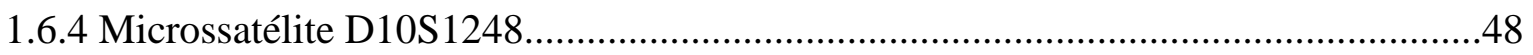

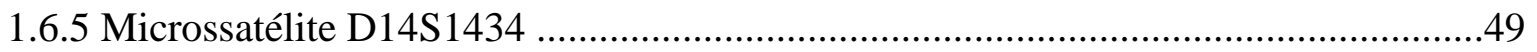

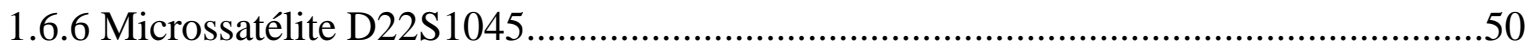

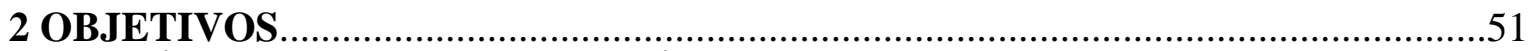

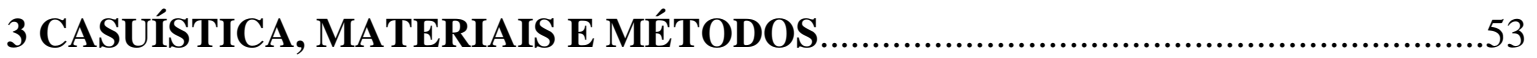

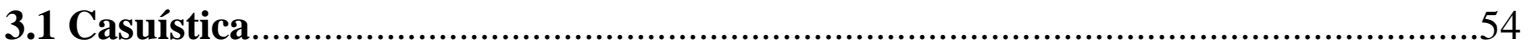

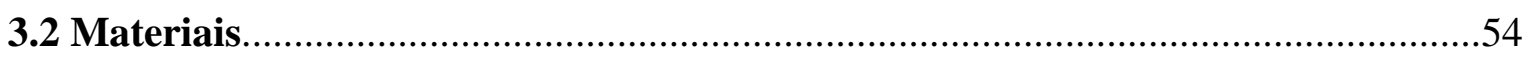

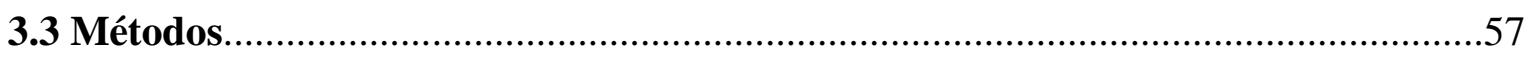

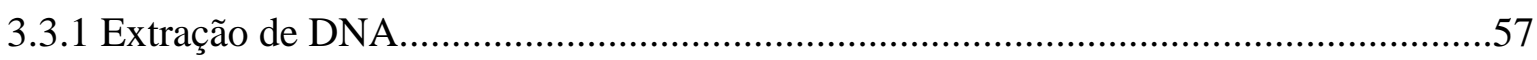

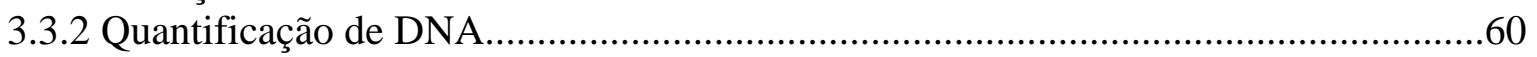

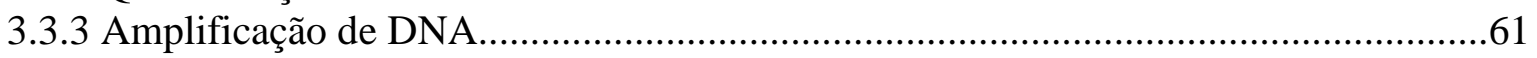

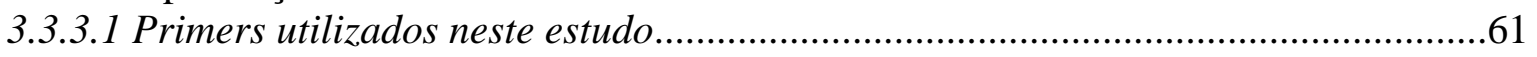

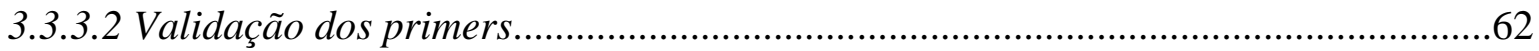

3.3.3.3 Validação das reações multiplex NC01 e NC02 .....................................................63

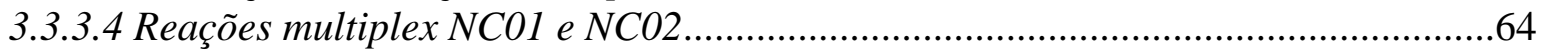

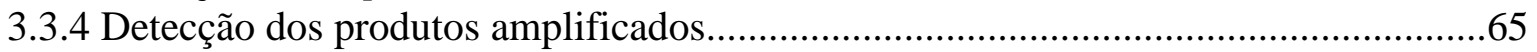

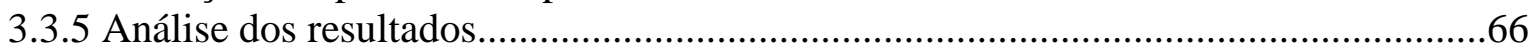

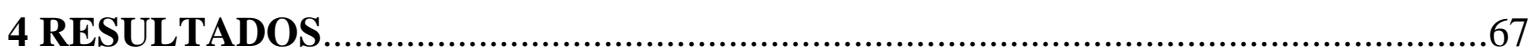

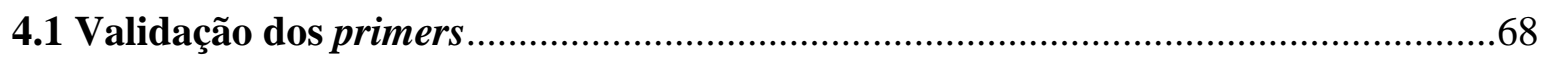

4.2 Validação das reações multiplex NC01 e NC02 ................................................. 71

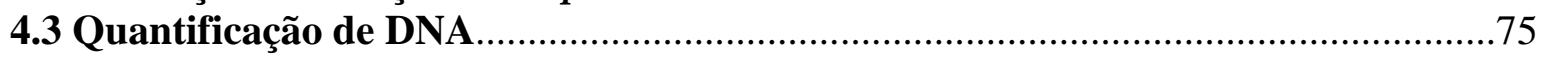

4.4 Amplificação das amostras para os sistemas NC01 e NC02 ................................78

4.4.1 Casos envolvendo identificação de cadáveres........................................................... 78 


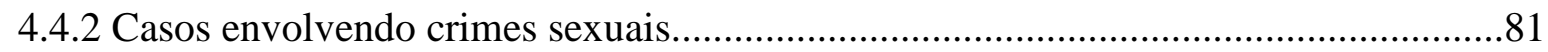

4.4.3 Casos de análise de vestígios biológicos oriundos de locais de crimes.......................86

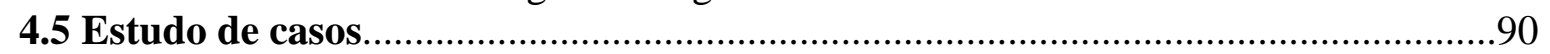

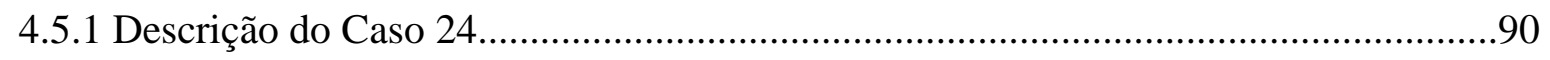

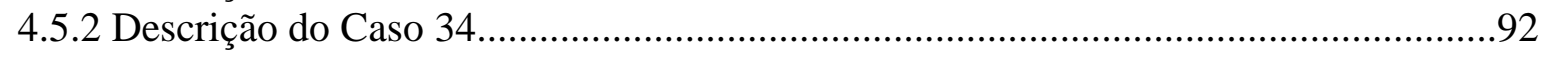

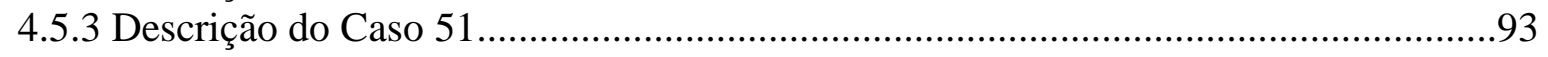

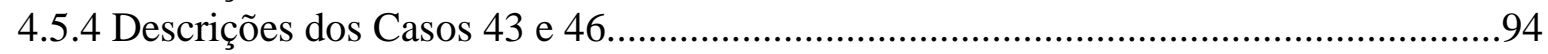

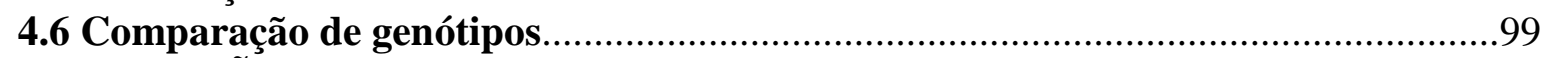

5 DISCUSSÃO

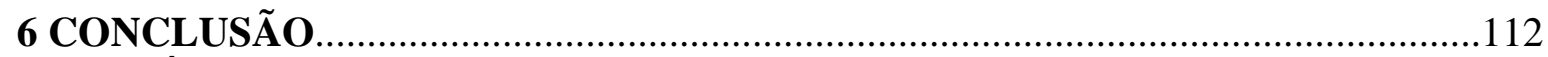

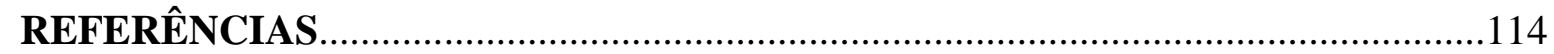

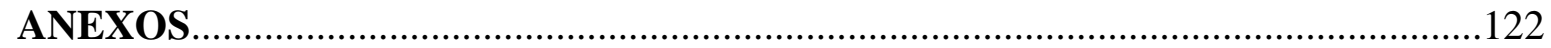

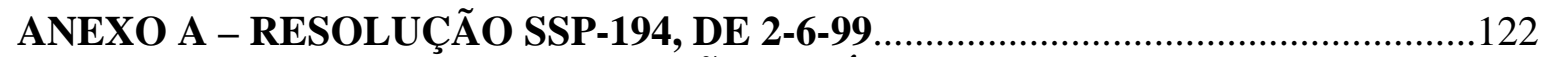

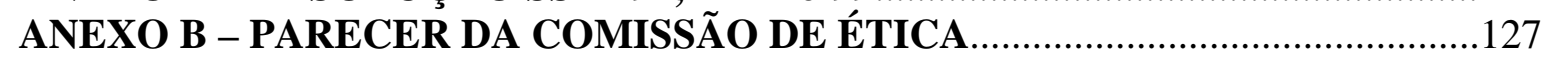

ANEXO C - TERMO DE CONSENTIMENTO LIVRE E ESCLARECIDO.............128

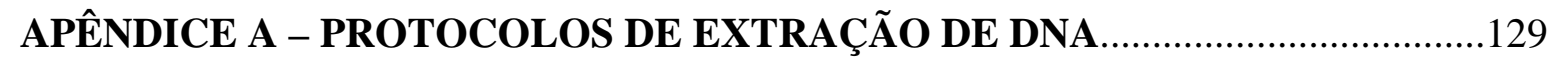


1 INTRODUÇÃO 


\subsection{Biologia forense}

Os avanços da ciência e tecnologia ocorridos principalmente nas duas últimas décadas impulsionaram de uma maneira geral a criminalística e aumentaram, por conseguinte, sua credibilidade e aceitação perante a sociedade como um todo. Tais avanços possibilitam também que as diversas áreas das ciências forenses como a Biologia, a Química, a Física, a Balística, entre outras, atuem cada vez mais no seu precípuo intuito como auxiliares imediatas da Justiça na elucidação das infrações penais.

Atualmente, os altos índices de ocorrências criminais (principalmente nas grandes cidades), a maior demanda de realização de perícias criminais, as tecnologias de ponta empregadas e, consequentemente, o maior grau de sucesso na resolução das problemáticas, além da intervenção e divulgação por parte dos meios de comunicação, ocasiona um interesse quase que generalizado pela Criminalística, seja pelos profissionais a ela diretamente conectados, seja por leigos.

Especificamente com relação à Biologia Forense e suas diversas subáreas, em praticamente todos os locais de crime podem ser encontrados vestígios de material biológico que, quando devidamente analisados e interpretados podem culminar com a descoberta de fatos fundamentais para a melhor aplicação da Justiça, seja por incriminar, seja por inocentar indivíduos.

\subsection{Coleta e cadeia de custódia de vestígios biológicos}

\subsubsection{Locais de crime e levantamentos técnico-periciais}

O mestre Eraldo Rabello, apud Stumvoll e Quintella (1996), no seu artigo Contribuição ao estudo dos locais de crime, define local de crime como a porção do espaço compreendida num raio que, tendo por origem o ponto no qual é constatado o fato, se extenda de modo a abranger todos os lugares em que, aparente, necessária ou presumivelmente, hajam sido praticados, pelo criminoso ou criminosos, os atos materiais, preliminares ou posteriores, à consumação do delito, e com este diretamente relacionados. Tal definição nos permite considerar, de forma generalista, que o local de crime é todo e qualquer local onde existam vestígios relacionados com o evento criminoso. Os vestígios, por sua vez, após devidamente analisados e interpretados, se tiverem estabelecida sua inequívoca relação com o fato 
delituoso e as pessoas a ele relacionadas passam a ser considerados indícios. Sendo assim, é natural estabelecer que o exame do local de crime seja o ponto de partida da investigação criminal, como diligência processual penal, implicando no exame de corpo de delito, direto ou indireto, com os seguintes objetivos (STUMVOLL; QUINTELLA, 1996):

- determinar se houve, ou não, uma infração penal;

- qualificar a infração penal;

- coletar elementos que porventura possibilitem a identificação do(s) autor(es);

- perpetuar os indícios materiais suscetíveis de serem utilizados futuramente como prova;

- legalizar os indícios.

Conforme determinação do texto legal do Código de Processo Penal (CPP), os tipos de levantamentos técnico-periciais a serem realizados num local de crime são os seguintes: descritivo na forma escrita; fotográfico; topográfico; papiloscópico; revelações, decalques, modelagens ou moldagens e reconstituição do local de crime.

1.2.2 Isolamento e preservação de local de crime

Para que o levantamento do local de crime seja eficaz e de extremo valor prático, é extremamente importante o completo isolamento e a preservação do local onde ocorreu a infração havendo, consequentemente, uma garantia de que o perito encontrará a cena do crime tal qual como fora deixada pelo infrator e pela vítima, possibilitando condições técnicas para a análise dos vestígios, sem interferentes "pós crime” (conforme apregoa o art. 169 do CPP).

O Estado de São Paulo editou em $1^{\circ}$ de setembro de 1999, através de sua Secretaria de Segurança Pública, a resolução n ${ }^{\circ}$ SSP 382 (SÃO PAULO, 1999a), que contém diretrizes sobre os procedimentos a serem seguidos contemplando os cuidados apropriados e a responsabilidade das carreiras policiais específicas na preservação dos locais de crime.

\subsubsection{Coleta de vestígios biológicos em local de crime}

Os vestígios biológicos de origem humana e animal mais comuns de serem encontrados em locais de crimes e cujos procedimentos de coleta já são de domínio da maioria do quadro policial envolvido são manchas de sangue, esperma, secreções vaginais, urina, fezes e saliva e os materiais coletados do próprio cadáver. Além disso, são 
normalmente encontrados cabelos, pelos, material subungueal e peças de vestuário ou outros objetos contendo células dos usuários.

A obtenção de sucesso nas análises a serem realizadas nos vestígios provenientes de um local de crime em muito depende do tipo das amostras colhidas e de como elas foram preservadas. Assim, a técnica utilizada para coletar e documentar o vestígio, a quantidade e o tipo de vestígio a ser colhido, o modo que o vestígio deve ser manuseado e embalado, e como o vestígio deve ser preservado são alguns pontos críticos para os exames (BONACCORSO, 2005).

Ao ser procedida a coleta dos vestígios e o acondicionamento dos mesmos, é regra fundamental que se procure manter suas integridades individuais, evitando-se a contaminação por contato, por misturas ou por material biológico do próprio indivíduo coletor. As embalagens utilizadas devem ser especiais, de acordo com as necessidades de acondicionamento e conservação do espécime que está sendo coletado.

Em todas as situações em que houver a possibilidade, devem ser coletadas amostrasreferência, ou seja, materiais biológicos sobre os quais não paira qualquer dúvida sobre a origem, para que possam ser utilizados em testes comparativos. Estes materiais podem ser coletados de vítimas, suspeitos, testemunhas, familiares e de outros materiais biológicos contaminantes e principalmente quando a preservação do local do crime não foi realizada de maneira adequada (tratando-se, portanto, de um local de crime não preservado, inidôneo ou violado). Considerando-se os aspectos éticos envolvidos na coleta deste tipo de amostrareferência, os indivíduos vivos fornecedores de amostras deverão fazê-lo facultativamente, de forma esclarecida, consentida e registrada na forma de algum documento, como é o caso, por exemplo, da assinatura de um termo de coleta de material biológico.

As orientações gerais que devem ser seguidas para a documentação, coleta, embalagem e preservação de vestígios biológicos a serem submetidos à análise estão nas recomendações comumente encontradas em manuais editados por órgãos ou entidades internacionais que fomentam ou procedem a análises em biologia forense e especialmente análises de DNA, como por exemplo os manuais do FBI (Federal Bureau of Investigation, 2007), da INTERPOL (International Criminal Police Organization, 2001) do GITAD (Grupo Iberoamericano de Trabajo en Análisis de DNA, 2002) e do GEP-ISFG (Grupo Español y Portugues de la International Society of Forensic Genetics, 2000).

No Estado de São Paulo, os materiais a serem submetidos a análises no Núcleo de Biologia e Bioquímica e particularmente no Laboratório de DNA do Instituto de 
Criminalística estão normatizados segundo a resolução da Secretaria da Segurança Pública de $n^{\circ}$ 194, de 02 de junho de 1999, Anexo 1 do presente trabalho (SÃO PAULO, 1999b).

De qualquer maneira, é importante salientar que treinamentos contínuos da equipe de profissionais responsáveis pela preservação e coleta dos vestígios biológicos são fundamentais para o sucesso das análises realizadas e para a obtenção de resultados úteis à elucidação das infrações penais.

\subsubsection{Cadeia de custódia de vestígios biológicos}

Segundo Bonaccorso e Perioli (2001), a cadeia de custódia pode ser definida como sendo o conjunto de procedimentos efetuados no levantamento do local de crime e no tratamento dos vestígios que, em última instância, irá garantir a credibilidade das provas e a imparcialidade em sua formação.

No sentido prático, refere-se a um conjunto de documentos que demonstrem todos os "passos percorridos" por um determinado vestígio no decorrer do seu processo de análise, incluindo em que condições ele foi coletado, a identidade de todas as pessoas que a ele tiveram acesso em cada uma das fases, a duração da custódia, as condições de segurança e armazenamento a que ele foi submetido e a maneira utilizada para se registrar todas as transferências do material a pessoas diferentes em cada fase (WIKIPEDIA, 2010).

As possibilidades técnicas de realização de uma prova pericial estão sujeitas à qualidade das amostras, o que em muitos casos, é inerente à própria amostra. Porém, muitas vezes, a qualidade depende dos processos de coleta e de armazenagem destas amostras até o momento das análises laboratoriais. Entretanto, a admissibilidade e a robustez das provas nos tribunais, dependem, principalmente, de como foram realizados os ditos processos e do cumprimento completo da cadeia de custódia ora mencionada (GONZALEZ, 2004).

\subsection{A identificação humana}

Como consequência direta da vida em sociedade, ao longo do tempo foram sendo desenvolvidos e utilizados diferentes métodos de identificação humana, necessários tanto nas esferas cível como criminal, seja durante a vida ou após a morte. A princípio, o método mais comum de identificação humana seria o próprio reconhecimento facial ou de características peculiares da pessoa como marcas, cicatrizes e tatuagens, por exemplo. 
Entretanto, segundo Del-Campo (2006), para que um método possa ser utilizado na prática com a finalidade de identificação humana, é desejável que ele cumpra alguns requisitos como:

- unicidade - os elementos selecionados para a identificação devem permitir a distinção clara e precisa entre o identificando e os demais;

- imutabilidade - as características analisadas não devem sofrer alteração com o passar do tempo;

- perenidade - os dados escolhidos devem perdurar por toda a vida;

- praticabilidade - permitir aos responsáveis uma coleta segura e prática dos dados, sem constrangimento ao identificando,com bom grau de confiança e que seja facilmente incorporada numa rotina de trabalho;

- classificabilidade - deve permitir a comparação entre dados, de forma precisa e sistemática, de forma a apontar o mais rápido possível o indivíduo na população;

- reprodutibilidade - capacidade de reproduzir os dados, fiel e continuamente, desde sua primeira obtenção.

A identificação de indivíduos através de impressões digitais e comparações odontológicas requer que registros prévios destas características estejam armazenados e disponíveis para comparação. Em algumas situações, principalmente em ocasiões post mortem, esses procedimentos de identificação não podem ser efetuados por impossibilidades em se realizar as devidas comparações, estando às vezes o cadáver em adiantado processo de decomposição ou esqueletização. Nestes casos são necessárias análises somatométricas das eventuais ossadas (ISCAN, 2001) ou o emprego da biologia molecular como auxiliar no processo de identificação (PRIMORAC; SCHANFIELD; PRIMORAC, 2000).

\subsubsection{A identificação humana na esfera criminal}

Após o encontro dos mais diversos tipos de vestígios em locais de crime estes devem ser colhidos e enviados para análises laboratoriais, para que possam ser obtidas informações técnicas relevantes para a reconstituição da cena do crime, na expectativa de solucionar sua dinâmica. Na grande maioria dos locais de crime e principalmente nos locais de crimes contra a pessoa são encontrados importantes vestígios biológicos de origem humana e que podem ser 
muito valiosos para a investigação criminal, pois podem estabelecer ligações entre indivíduos, objetos e lugares, podendo vincular ou até desvincular uma determinada pessoa de um crime.

O objetivo do geneticista forense é o de identificar com maior certeza possível a origem de uma amostra biológica. Em se tratando de material de origem humana, as variações atualmente conhecidas na molécula de DNA (os polimorfismos) são extremamente informativas e possibilitam a identificação de indivíduos com elevado grau de certeza (JOBLING; GILL, 2004). Entretanto, antes de se realizar as análises de DNA propriamente ditas, os vestígios de origem biológica devem passar por etapas de constatação através de testes preliminares para verificação da sua real autenticidade como vestígio biológico humano e também a métodos preparatórios em função do estado muitas vezes longe do ideal em que os vestígios são recebidos no laboratório.

Os procedimentos aqui descritos são os rotineiramente utilizados na identificação de vestígios biológicos de origem humana no Núcleo de Biologia e Bioquímica do Instituto de Criminalística da Superintendência da Polícia Técnico-Científica do Estado de São Paulo (o que retrata, devidas as proporções, a situação no Brasil) e que atualmente possui em seu quadro de funcionários 18 peritos criminais, com formação na área de ciências biológicas (sendo uma Diretora, uma Diretora Substituta, sete peritos responsáveis pelos testes de constatação de vestígios biológicos e nove peritos responsáveis pelas análises no Laboratório de DNA).

1.3.2 Testes de constatação de vestígios biológicos humanos

O sangue é o mais comum e provavelmente a mais importante forma de vestígio de origem humana para a justiça criminal mundial atual (FORENSIC SEROLOGY, 2010) e pode ser encontrado tanto em objetos, armas, móveis, paredes, pisos, e peças de vestuário de vítimas e suspeitos, entre outras inúmeras localizações (STUMVOLL; QUINTELLA, 1996).

Existem diversos reagentes comerciais que podem ser utilizados no próprio local de crime para a constatação da presença de manchas de sangue (TOBE; WATSON; DAÉID, 2007). Em laboratório, quando são recebidas peças com vestígios de aspecto hematóide, porções delas recolhidas são submetidas a "Ensaios genéricos de orientação para sangue" que são basicamente ensaios químicos que permitem presumir se determinada substância é sangue ou contém sangue. Os principais destes ensaios baseiam-se na atividade da hemoglobina semelhante à da peroxidase e são realizados com o emprego do Reagente de Kastle-Meyer (fenolftaleína+hidróxido de sódio+zinco) e de água oxigenada ou do Reagente 
de Adler (benzina+ácido acético) e água oxigenada. Após a constatação preliminar da presença de sangue ter resultado positiva, são realizados testes para a verificação da procedência humana deste material através de reações imunológicas de antígeno-anticorpo como o "Ensaio específico de proteína humana". Ainda na sequiência da marcha analítica, quando houver amostra em quantidade suficiente, podem ser feitos ensaios de tipagem sangüínea para o sistema $\mathrm{ABO}$ e para o fator $\mathrm{Rh}$ seguindo-se o método das diluições progressivas ou técnica de Holzer ou ainda a técnica de Absorção/Eluição (ZARZUELA; MATUNAGA; THOMAZ, 2000).

Outro vestígio dos mais comumente analisados em laboratório é o sêmen. Da mesma forma que para os vestígios de sangue, são realizados ensaios presuntivos para a presença de líquido seminal através da pesquisa de proteínas ou enzimas no material questionado, através de métodos enzimáticos ou imunológicos, como é o caso da fosfatase ácida prostática e do antígeno prostático específico. Resultados positivos para as duas substâncias acima mencionadas são fortes indicativos da presença de sêmen no material pesquisado, entretanto, ainda são realizados ensaios de certeza através da observação de espermatozóides ao microscópio óptico com características próprias dos espermatozóides humanos (ZARZUELA; MATUNAGA; THOMAZ, 2000).

Ainda são realizados em laboratório, testes de constatação para a presença de urina (detectando-se a enzima urease através do Reagente de Nessler), de fezes (pesquisando-se o urobilinogênio), de saliva (constatando-se a enzima amilase) e a identificação e comparação de pelos ou cabelos através de análises microscópicas.

Além dos materiais acima mencionados, são também recebidas nos laboratórios amostras de unhas humanas e ossos, dentes e vísceras cadavéricas, seja de amostrasreferência, como de amostras questionadas.

Praticamente todos os materiais enviados aos laboratórios requerem procedimentos de limpeza, secagens, recortes e amostragens antes de serem submetidos aos testes anteriormente descritos, como também para que possam ser empregados em análises de DNA.

\subsection{A identificação humana por análise de DNA}

\subsubsection{Aspectos históricos}


Os progressos da Biologia Forense com finalidades de Identificação Humana podem ter sido considerados lentos durante uma certa época, mas desde 1985 técnicas mais poderosas ocasionaram um crescimento explosivo nesta área. O primeiro sistema de marcadores úteis, os grupos sangüíneos ABO, foram descobertos por volta de 1900. O segundo grupo de marcadores, os antígenos $\mathrm{MN}$ do sangue, vieram somente aproximadamente 25 anos depois. A demonstração da ocorrência de um sistema de histocompatibilidade, conhecido por complexo HLA (histocompatibility leucocyte antigen), em 1954, trouxe grandes préstimos à Medicina Forense e marcou uma segunda fase na evolução da Imunogenética (BONACCORSO, 2005). Por volta da década de 60, já havia 17 sistemas de grupos sangüíneos conhecidos, mas nem todos possuíam utilidade na área forense e nos anos 70 mais algumas proteínas séricas e enzimas puderam prestar sua contribuição. No decorrer da década de 80, por volta de 100 polimorfismos de proteínas já haviam sido estudados e descritos, mas com pouca expressividade na área forense (NIJ, 2000).

A descoberta da dupla hélice do Ácido Desoxirribonucléico (DNA) como componente responsável pelo patrimônio genético dos seres vivos, em 1953, por Watson e Crick revolucionou a Biologia e ocasionou mudanças importantes em diversas áreas da ciência, desenvolvendo-se a partir de então técnicas capazes de caracterizar as particularidades no DNA de cada indivíduo (BUCKLETON; TRIGGS; WALSH, 2005).

O ano de 1985 foi decisivo com a descoberta pelo geneticista inglês Dr. Alec Jeffreys, de algumas regiões do DNA que continham sequências repetitivas consecutivas (com tamanho geralmente entre 8 e 35 bases nitrogenadas) e que o número de repetições (de 100 ou mais vezes) destas sequiências poderia diferir de indivíduo para indivíduo (JEFFREYS; WILSON; THEIN, 1985a, 1985b). Estes polimorfismos, que ficaram posteriormente conhecidos como VNTRs (regiões de repetições consecutivas de número variável, do inglês variable number tandem repeats), ou também minissatélites, por sua grande variabilidade na população quando comparados com os sistemas utilizados anteriormente, passaram a ser prontamente empregados em estudos forenses e de início foram utilizados na Inglaterra para resolver um caso de imigração e, logo em seguida, de estupro seguido de homicídio. Nos Estados Unidos da América, o FBI iniciou a utilização deste sistema em 1986. A técnica empregada pelo Dr. Jeffreys - conhecida como RFLP (polimorfismo de comprimento do fragmento de restrição, do inglês restriction fragment length polymorphism), que utiliza enzimas de restrição que são capazes de cortar a molécula de DNA em regiões específicas ao redor dos VNTRs e que é capaz de gerar resultados que ficaram conhecidos como “impressões digitais" de DNA, ainda é utilizada por poucos laboratórios mas, devido ao seu 
processo técnico trabalhoso e demorado e por não ser muito útil em amostras de DNA degradadas, veio sendo gradualmente substituída pelo emprego de técnicas baseadas no estudo de polimorfismos conhecidos como STRs (regiões de repetições consecutivas curtas, do inglês short tandem repeats) ou microssatélites (BUTLER, 2005). Estes são atualmente empregados com a finalidade de identificação humana na maioria dos laboratórios forenses brasileiros e internacionais (JOBLING; GILL, 2004).

Mais recentemente vem sendo estudados e lançados no mercado, produtos baseados na análise dos denominados mini-STRs que diferem dos acima citados somente por originarem fragmentos de DNA menores após a reação de amplificação e que podem oferecer resultados mais consistentes e robustos nos casos em que se analisam amostras de DNA sobremaneira degradadas.

Sequencialmente no aspecto histórico, foram descritos e ainda estão sendo estudados (já com diversas aplicações na área forense) os polimorfismos de sequiência do tipo SNPs (polimorfismos de nucleotídeo único, do inglês single nucleotide polymorphism) que ocorrem aos milhares em cada indivíduo e os polimorfismos de seqüência no DNA mitocondrial que são bastante úteis por ser este DNA muito mais abundante em termos de número de cópias do que o DNA nuclear nas células e por fornecer informações genéticas da origem matrilínea de uma determinada amostra. Há ainda os polimorfismos localizados em regiões específicas do cromossomo $\mathrm{Y}$ que têm sido empregados no estabelecimento de amostras de uma mesma origem ancestral paterna (NIJ, 2000).

Os avanços tecnológicos e as descobertas científicas descritas acima possibilitaram o uso rotineiro das técnicas de análise de DNA na área forense, aliadas a processos de automação e informatização laboratorial, minimizando o tempo na obtenção de resultados e com um menor índice de erros.

\subsubsection{A molécula de DNA e os polimorfismos genéticos}

O DNA, ácido desoxirribonucleico, é a molécula de nossa herança genética e componente de praticamente todos os organismos vivos. Diferentemente das proteínas, consideradas como sendo o produto final dos processos de manufatura celulares, o DNA seria o elemento arquitetônico que especifica quando a síntese celular deve ocorrer e que codifica a sequência informacional para todos os componentes estruturais do corpo. Desta forma, é possível obter DNA de praticamente todos os tecidos do corpo humano, incluíndo sangue, cabelos, ossos e sêmen, por exemplo, variando apenas a quantidade que é possível extrair de 
cada um desses tecidos (RUDIN; INMAN, 2002). Este elemento é herdado diretamente dos pais e é construído originando um indivíduo único que compartilha similaridades e diferenças com seus ancestrais. Com exceção das hemácias e dos gametas, cada uma das trilhões de células do corpo humano apresentam 46 cromossomos e mais do que 3 bilhões de pares de bases de informação genética. É uma sequência única de um código genético simples de quatro nucleotídeos que determina a diferença de aproximadamente $0,1 \%$ encontrada entre cada indivíduo. As moléculas de DNA, assim como os indivíduos, são mais parecidas entre si do que diferentes e a ciência forense se encarrega de decifrar estas pequenas diferenças na herança genética.

A molécula de DNA é composta por basicamente três tipos de componentes químicos: fosfato, um açúcar denominado desoxirribose e quatro bases nitrogenadas - adenina (A), guanina $(\mathrm{G})$, citosina $(\mathrm{C})$ e timina $(\mathrm{T})$, sendo as duas primeiras purinas e as restantes pirimidinas. Estes componentes químicos se arranjam em grupamentos denominados nucleotídeos que formam cadeias em seqüência através de ligações do tipo fosfodiéster e que, por sua vez, interagem com outra cadeia através da complementariedade das bases (adenina com timina A-T e citosina com guanina $\mathrm{C}-\mathrm{G}$ ) e de pontes de hidrogênio, conferindo a estrutura de dupla hélice do DNA (GRIFFITHS et al., 1999).

A sequência assumida pelos nucleotídeos na molécula de DNA varia entre os indivíduos, tornando-os únicos (exceto para os gêmeos idênticos, univitelinos) e possibilitando o emprego de técnicas de estudo desta molécula para identificação humana (BUTLER, 2005).

A molécula de DNA se estrutura no interior das células na forma de cromossomos. Os cromossomos denominados homólogos possuem o mesmo tamanho e contêm a mesma estrutura genética. Uma cópia de cada gene está localizada na mesma posição (locus) de cada cromossomo, no par homólogo e as alternativas possíveis para um dado gene ou locus genético são denominadas alelos. Se o mesmo alelo for observado em ambos os cromossomos de um par de homólogos o indivíduo é considerado homozigoto para aquele locus, se forem alelos diferentes, denomina-se heterozigoto (JOBIM; JOBIM; BRENNER, 1999).

A união dos gametas no momento da fecundação determina a formação de um novo indivíduo, no qual pode ser constatada uma mistura do DNA materno com o DNA paterno, que será replicado através das sucessivas divisões celulares. A molécula de DNA deste indivíduo será então composta por genes, responsáveis pela determinação das proteínas celulares, mas também em muito maior proporção por regiões não codificadoras de proteínas, com funções não tão bem definidas e apresentando regiões com repetições de sequências. A 
possível função de regulação genética atribuída a estas regiões não codificadoras não se sobrepõe, entretanto, à sua grande e significativa contribuição para a evolução da espécie humana, já que o alto grau de variações nas sequências destas regiões entre os indivíduos são responsáveis por tantas diferenças adaptativas entre espécies quanto as alterações nas proteínas (CONSELHO NACIONAL DE PESQUISA - NRC, 1996). As sequências de DNA localizadas fora das regiões codificadoras, por sofrerem menor pressão de seleção, apresentam maior variabilidade entre os indivíduos e justamente por isso são recomendáveis para as análises de identificação humana.

O DNA é a molécula de escolha para a identificação humana forense principalmente pelos quatro seguintes motivos:

- Poder de discriminação - com exceção dos gêmeos monozigóticos (idênticos), não há duas pessoas que compartilhem o mesmo perfil genético. Os gemêos idênticos são essencialmente clones um do outro;

- Continuidade genética - o DNA encontrado em cada uma de nossas células no nascimento contém o mesmo padrão genético que estará presente no momento de nossa morte. Diferentes fontes biológicas de DNA encontradas em locais de crime irão compartilhar um padrão idêntico se elas forem originadas de uma só pessoa, independentemente da parte do corpo de qual foram provenientes. Além disso, a continuidade genética se extende através das gerações permitindo que membros de uma família sejam identificados por similaridades dos genótipos de DNA;

- Sensibilidade - poucas gotas de sangue, um swab bucal ou uma pequena mancha de sangue geralmente contêm quantidades de amostra suficientes para a análise forense de DNA. Os métodos atuais envolvendo a reação da polimerase em cadeia (PCR) podem ser bem sucedidos até com amostras mais escassas, desde a saliva (e as células nela contidas) encontrada em abas de envelopes e selos, até manchas de sêmen muito escassas;

- Estabilidade - a molécula de DNA, sendo constituída dos grupamentos fosfato, dos açúcares e das bases nitrogenadas, se estrutura formando uma molécula extremamente estável capaz de suportar intempéries ambientais naturais e artificiais, diferentemente dos vestígios sorológicos que compreendem proteínas lábeis. A integridade da molécula de DNA é provavelmente a característica forense de destaque que permite que ao perito transcender no tempo e conectar casos antigos com vestígios recém-encontrados ou ainda 
identificar vítimas de desastres de massa como quedas de aeronaves ou explosões, por exemplo.

Conforme mencionado, existem regiões do DNA que apresentam repetições consecutivas de uma determinada sequência de bases nitrogenadas. O tamanho destas sequências de DNA repetitivo determina sua classificação em minissatélites ou regiões de repetições consecutivas de número variável (VNTR) e microssatélites ou regiões de repetições consecutivas curtas (STR).

Os STRs diferem dos VNTRs pelo fato do número de nucleotídeos que formam o bloco de repetição ser menor, de 2 a 7 bases nitrogenadas (Figura 1), possibilitando sua amplificação através da reação de PCR (reação em cadeia da polimerase, do inglês polymerase chain reaction) (LYGO et al., 1994). Acredita-se que os polimorfismos do tipo STR se originem por falhas no momento da replicação do DNA, pela "derrapagem" da enzima polimerase (polymerase slippage), causando aumento ou diminuição do número de unidades de repetição. Quando tais falhas de replicação ocorrem na formação dos gametas, as alterações são transmitidas aos descendentes. Estas regiões de DNA repetitivo ocorrem frequentemente na sequência genômica, seja em regiões codificadoras ou não codificadoras, exons, introns, regiões promotoras e/ou estimuladoras, perfazendo aproximadamente $15 \%$ do genoma humano (BENNETT, 2000).

\section{AACTGGCTGACTGACTGACTGACTGACTGACTGACTGACTGACCTGGGC}

Figura 1 - Representação de sequência de bases nitrogenadas do DNA, apresentando 9 repetições consecutivas do bloco CTGA (alelo 9), exemplificando um microssatélite (STR).

O polimorfismo na molécula de DNA refere-se ao número de alelos que uma dada região da molécula apresenta. Se um locus apresentar 2 ou mais possibilidades, com frequência maior do que $1 \%$, é possível considerá-lo um locus polimórfico, ou polimorfismo genético. Para uma dada população, poderá ser estudada a proporção dos alelos, ou seja, a frequência alélica populacional. O maior número de alelos presente num microssatélite, ou seja, quanto maiores forem as variações de repetições da sequência polimórfica, o seu menor tamanho, a maior frequência de heterozigotos (acima de 90\%) e uma baixa taxa de mutação favorecem muito o seu emprego na identificação humana (JOBIM; JOBIM; BRENNER, 1999). A nomenclatura dos alelos dos STRs, de acordo com a ISFG (International Society of 
Forensic Genetics), se dá de acordo com o número de repetições observadas, ou seja, um locus que apresentar 9 repetições da sequência polimórfica, deverá ser designado como alelo 9, por exemplo (Figura 1).

Pelas razões já expostas, a genotipagem de microssatélites autossômicos do tipo STR com detecção dos produtos marcados com fluoróforos por eletroforese capilar tem sido uma ferramenta amplamente utilizada nos laboratórios de análise forense de DNA (BRETTELL; BUTLER; ALMIRALL, 2009; JOBLING; GILL, 2004) principalmente com os seguintes objetivos:

1. identificação de cadáveres: exames feitos em amostras cadavéricas como ossos, dentes, músculos, vísceras e outras fontes celulares, com comparação com amostras-referência de supostos familiares;

2. crimes sexo-relacionados: com objetivo de futuro confronto, constatando-se inicialmente a presença de espermatozóides e de material masculino com obtenção antecipada de perfis genéticos; realizada em peças de vestuário, swabs e esfregaços em lâminas de microscopia ou em casos de confronto entre materiais da vítima (amostras questionadas e amostras-referência) e amostras-referência de suspeito(s) e companheiro sexual consentido, quando pertinente;

3. confrontos genéricos: realizados entre amostras questionadas, geralmente coletadas em local de crime, e amostras-referência do suspeito, da vítima ou de ambos;

4. testes de paternidade nas áreas cível e criminal, sendo que neste último o exame é realizado com amostras da vítima de estupro, da criança e do suspeito.

Além da utilidade dos marcadores microssatélites em identificação humana, estes são também empregados como rastreadores para algumas doenças genéticas, já que em alguns casos é possível estabelecer associações entre os marcadores e doenças humanas e/ou outras características dos indivíduos (KLINTSCHAR et al., 2004; SHARMA et al., 1998).

O processo técnico para análise de microssatélites geralmente envolve a coleta e a preservação da amostra, a extração e a quantificação do DNA seguida da amplificação por PCR de múltiplos loci STR, a separação dos fragmentos amplificados por eletroforese capilar, a genotipagem, a interpretação do perfil genético obtido e as análises estatísticas comparativas.

Os vestígios provenientes de locais de crimes normalmente estão sujeitos a insultos ambientais (condições de iluminação, variações de temperatura, contato com substâncias químicas corrosivas, ataques enzimáticos, contaminação e consequente degradação por 
microorganismos) que determinam alterações na estrutura original da molécula de DNA evetualmente neles presentes (BONACCORSO, 2005). Estudos realizados por Chung et al. (2004) demonstraram que o DNA genômico, quando submetido à degradação orgânica, por microorganismos ou bioquímica, pode ter seu comprimento consideravelmente reduzido, gerando moléculas com comprimentos menores do que 300pb. Além disso, processos oxidativos, incidência de radiação (luz), umidade e variações constantes de temperatura também contribuem fortemente para a fragmentação do DNA das amostras forenses, ocasionando a obtenção de perfis genéticos parciais, ou mesmo a sua não-obtenção, dificultando sobremaneira os processos de identificação humana por análise de DNA (WEEDN; SWARNEN, 1998).

A amplificação do DNA extraído de pequenas quantidades de amostras biológicas relacionadas com eventos criminais, com produtos de tamanho em torno de 100 a 150 pares de bases, gerados nas análises de STRs são extremamente compatíveis com a qualidade do DNA destas amostras, que muitas vezes apresentam-se exíguas e que foram submetidas a processos de degradação dos mais diversos. Além disso, a possibilidade de se estudar simultaneamente várias regiões polimóficas, através de reações do tipo multiplex, com o uso de diferentes fluoróforos e tamanhos distintos de produtos amplificados, determina análises com alto poder de discriminação entre indivíduos da população, num período de tempo relativamente rápido, sem contudo, consumir grandes quantidades de reagentes e do próprio DNA extraído (BUTLER, 2007).

Existem na atualidade kits comerciais que disponibilizam reagentes próprios para a amplificação simultânea de um conjunto de sequências polimórficas, simplificando a obtenção e o intercâmbio de dados entre laboratórios e também possibilitando uma uniformidade na inserção dos perfis genéticos em bancos de dados específicos. A grande maioria dos laboratórios forenses manifesta uma certa preferência em utilizar estes kits comerciais, em detrimento dos processos de amplificação "in-house", apesar de seu maior custo, pelo fato de apresentarem uma maior facilidade na execução do processo, uma maior confiabilidade com relação ao controle de qualidade exigido, bem como por já disporem em sua composição de escadas alélicas dos alelos mais representativos da população para cada locus. Entretanto, para que estes kits de reagentes apresentem um desempenho satisfatório, resultando na obtenção do perfil alélico completo do indivíduo para as regiões analisadas, são necessárias amostras de DNA íntegro, não degradado e praticamente livre de contaminantes ou impurezas que possam causar inibição da enzima responsável pela amplificação do DNA na reação de PCR. 
As condições de degradação do DNA ou de contaminação por inibidores da reação de PCR das amostras recebidas em laboratórios forenses e as consequentes dificuldades na obtenção de resultados, principalmente dos fragmentos maiores, determinou nos últimos anos o desenvolvimento de técnicas mais sensíveis em que se estudam STRs de tamanho reduzido, conhecidos por miniSTRs. Os miniSTRs referem-se aos mesmos polimorfismos, mas cujas técnicas de análise foram desenvolvidas para originarem fragmentos de DNA menores após a reação de PCR, devido a deslocamentos na região de ligação dos primers para o mais próximo possível da região polimórfica repetitiva, gerando produtos de amplificação menores e que podem oferecer resultados mais consistentes e robustos nos casos em que se analisam amostras de DNA muito degradadas (WIEGAND; KLEIBER, 2001; BUTLER; SHEN; McCORD, 2003; COBLE; BUTLER, 2005; COBLE et al., 2006; DIXON et al., 2006; OPEL et al., 2007). Há uma grande expectativa para a utilização conjunta dos sistemas que analisam STRs e mini-STRs, fornecendo uma maior segurança e mais facilidade nas análises de DNA de amostras degradadas (Figura 2).

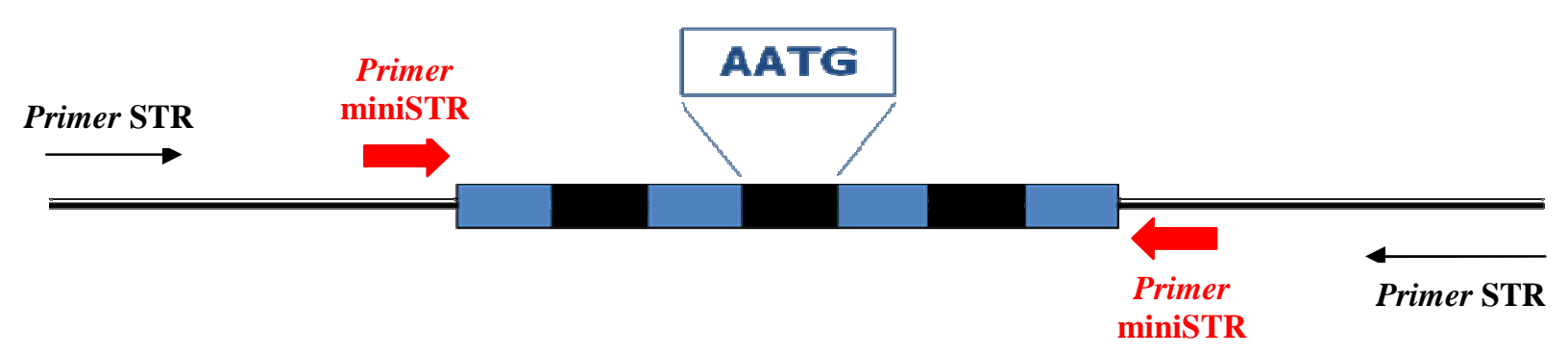

Figura 2 - Representação ilustrativa da diferença da posição dos primers em relação ao início da sequência repetitiva no caso de STRs e miniSTRs.

\subsubsection{Etapas técnicas da análise forense de DNA}

Após os procedimentos de coleta e exames preliminares, os vestígios biológicos relacionados com eventos criminais são submetidos a um processo sequencial de etapas técnicas até que se atinja o objetivo final que é a análise do perfil genético da amostra.

\subsubsection{Extração do DNA}

Para que o DNA presente numa amostra forense possa ser submetido à genotipagem, é necessário inicialmente obtê-lo na forma de uma solução de trabalho, através de processos de 
extração química, a partir dos quais o DNA nuclear (ou o mitocondrial, quando aplicável) será removido do interior das células. Existem atualmente diversas metodologias para a extração do DNA e a escolha de uma delas se baseia no tipo do material biológico estudado, no seu estado de conservação, na quantidade disponível e no grau de pureza necessário para as aplicações subseqüentes.

Os métodos de extração de DNA, seja orgânicos ou inorgânicos, baseiam-se genericamente nos mesmos processos nos quais inicialmente ocorre o rompimento (ou lise) das células e a solubilização do DNA no meio, seguido de estratégias para a eliminação de proteínas e outros interferentes indesejados e finalmente a precipitação ou captura do DNA por algum sistema.

Existem diversos reagentes comerciais (chamados de kits) no mercado que são amplamente empregados para extração e purificação do DNA, utilizando resinas que tem alta afinidade pela molécula do DNA, aliados à rapidez dos processos e minimização das possibilidades de contaminação de amostras. Entretanto, ainda não foram abandonados alguns dos métodos tradicionais "in-house", em que os reagentes são preparados no próprio laboratório, muitos por apresentarem custo bem menor ou por serem bastante eficientes para determinados tipos de amostras. Nos crimes sexuais, geralmente as amostras a serem analisadas correspondem a misturas de espermatozóides e células epiteliais da vítima. Nestes casos, utilizam-se, de forma muito eficiente, procedimentos de extração diferencial que empregam detergentes fracos para liberar DNA das células epiteliais, seguidos da utilização de detergentes fortes para liberar o DNA dos espermatozóides. Isoladas as frações, ambas são submetidas à extração por outros métodos tradicionais, de escolha do laboratório (BONACCORSO, 2005).

\subsubsection{Quantificação do DNA extraído}

O conhecimento do rendimento dos métodos de extração empregados para a extração do DNA é de fundamental importância para que não haja excesso ou falta de moléculas a serem utilizadas no próximo passo da análise, a reação de amplificação do DNA. A reação de PCR tem como possível interferente quantidades excessivas de DNA molde e apesar de, em tese, ser capaz de amplificar uma única molécula de DNA, também apresenta dificuldades nos casos em que o DNA está muito escasso ou degradado. A mensuração de quantidades ínfimas de DNA humano, característica marcante dos vestígios criminais biológicos, é um passo crucial na análise do DNA para obtenção de resultados precisos no menor prazo de tempo 
possível. Neste sentido, inúmeras recomendações internacionais, dentre elas o DAB (DNA Advisory Board, FBI 2000), recomenda em suas diretrizes analíticas a quantificação de DNA humano presente no vestígio a ser genotipado.

Existem diversos métodos para quantificação do DNA extraído de uma determinada amostra; podem ser feitas eletroforeses em géis de agarose e posterior "visualização" do DNA intercalado com corantes fluorescentes sob luz ultravioleta, ensaios espectrofotométricos medindo a absorbância da solução em 260nm (nanômetros), sendo que estes dois métodos podem sofrer interferências por DNAs contaminantes de microorganismos. Há também metodologias conhecidas como "Slot Blot" que se baseiam na utilização de sondas específicas para DNA humano e posterior revelação por quimioluminescência ou colorimetria (BUTLER, 2005).

Atualmente estão sendo empregados ensaios de PCR em tempo real (Real Time-PCR) que detectam a amplificação das moléculas de DNA em tubos de reação, através de emissão simultânea de fluorescência por parte de sondas e que são capazes de detectar quantidades até inferiores que $100 \mathrm{pg}\left(100 \times 10^{-12} \mathrm{~g}\right)$ de DNA. A quantificação de DNA por PCR em tempo real pode diminuir sensivelmente os consumo de reagentes, o tempo de processamento das amostras até a emissão do laudo e o tempo de trabalho do perito em cada vestígio criminal.

\subsubsection{Amplificação do DNA}

Na maioria das vezes, o DNA obtido de amostras forenses encontra-se em porções tão diminutas que impossibilitariam sua extração e análise mais minuciosa por outras metodologias e posterior genotipagem. Entretanto, após a descoberta da reação de PCR (reação em cadeia da polimerase, do inglês polymerase chain reaction), em 1985, pelo pesquisador Kary Mullis e por membros do Grupo de Genética Humana da Cetus Corporation (atualmente Roche Molecular Systems) (SAIKI et al., 1988), toda a comunidade forense e a medicina diagnóstica foram beneficiadas pelo fato desta reação ter a capacidade de amplificar uma seqüência específica do DNA, gerando milhões de cópias desta em apenas poucas horas, possibilitando posteriores utilizações em outros ensaios experimentais (BUTLER, 2005).

O processo da PCR é teoricamente simples e simula in vitro o processo pelo qual as células replicam seu DNA in vivo. Trata-se de uma reação enzimática, catalisada por uma proteína do tipo polimerase, que tem a habilidade de acrescentar nucleotídeos a uma seqüência inicial de DNA, seguindo a complementariedade das bases nitrogenadas com 
relação a uma fita molde. Tal polimerase é termoestável, dependente da presença de íons magnésio $\left(\mathrm{Mg}^{2+}\right)$ num meio tamponado, e um processo de ciclagem de temperaturas que normalmente ocorre em três etapas ocasiona a multiplicação das moléculas do DNA molde presente na solução. As três etapas básicas de uma reação de PCR são:

- Desnaturação (melting): consiste na elevação da temperatura para aproximadamente $95^{\circ} \mathrm{C}$ para que ocorra a separação da dupla fita de DNA;

- Anelamento (annealing): em temperaturas por volta de $60{ }^{\circ} \mathrm{C}$, ocorre a hibridização, por complementariedade, de seqüências de DNA iniciadoras (contendo aproximadamente 20 bases nitrogenadas de comprimento e também conhecidas como primers) que são específicas para a região do DNA que se pretende amplificar;

- Extensão (extension): nesta fase ocorre a adição dos nucleotídeos complementares (que são adicionados ao meio de reação na forma dos desoxinucleotídeos dATP, dCTP, dGTP e dTTP), por ação da polimerase, numa faixa de temperatura ótima por volta dos $70{ }^{\circ} \mathrm{C}$, até que se alcance a região delimitada pelos primers.

Teoricamente, após 30 ciclos de PCR (de desnaturação, anelamento e extensão), uma única molécula de DNA é amplificada de maneira exponencial, gerando ao final da reação 268.435.456 cópias. Há que se considerar, porém, que estes valores se referem a uma reação totalmente eficiente, o que não ocorre na prática (BUCKLETON; TRIGGS; WALSH, 2005).

As estratégias atuais de amplificação envolvem a utilização simultânea de diversos pares de iniciadores (primers), de forma que várias regiões do DNA podem ser amplificadas numa só reação, num formato denominado de reação de PCR multiplex. Além disso, para que seja possível a diferenciação de produtos de PCR multiplex com tamanhos em pares de bases semelhantes, são utilizados marcadores como moléculas fluorescentes ligadas aos primers específicos de cada região que se deseja amplificar, gerando cópias de DNA que, quando excitadas por fonte energética emitirão luz com comprimento de onda característico do fluoróforo empregado. Há disponíveis no mercado, diversos reagentes comerciais (kits) que são compostos pelos reagentes necessários para a amplificação de vários loci cromossômicos humanos, microssatélites, baseados em reações do tipo multiplex, com posterior detecção de fluorescência.

Entretanto, para que estes kits apresentem um desempenho satisfatório, resultando na obtenção do perfil alélico completo do indivíduo para as regiões analisadas, são necessárias 
amostras de DNA íntegro, não degradado e praticamente livre de contaminantes ou impurezas que possam causar inibição da enzima responsável pela amplificação do DNA na reação de PCR.

\subsubsection{Detecção do DNA amplificado}

Conforme já mencionado anteriormente, os polimorfismos do tipo STR têm sido os mais frequentemente utilizados nas análises de DNA de amostras forenses. Após sua amplificação pela reação de PCR, os produtos de reação são geralmente submetidos a um processo de eletroforese, no qual os fragmentos de DNA, contendo carga residual negativa, são submetidos a uma diferença de potencial elétrico e migram na direção do eletrodo que apresenta carga positiva, sobre um suporte que pode ser um gel de poliacrilamida, ou mais atualmente na forma de uma eletroforese que ocorre no interior de um capilar em equipamentos automatizados dotados de sistemas de detecção que utilizam feixes de laser para reconhecer os fluoróforos específicos utilizados para a marcação dos primers. Nas janelas de detecção dos equipamentos são reconhecidos os comprimentos de onda emitidos pelos fluoróforos e estes são convertidos em sinais digitalizados na forma de bandas ou picos. A ordem de migração das moléculas é determinada pelo seu tamanho, sendo que as menores percorrerão mais rapidamente uma mesma distância do que as moléculas maiores. Juntamente com as amostras questionadas, também são submetidas à eletroforese, em paralelo, controles de reação e escadas alélicas (allelic ladders) que são um conjunto de fragmentos de DNA representativos dos alelos mais comuns na população para as regiões do DNA analisadas.

\subsubsection{Interpretação dos resultados}

Após a obtenção dos perfis genéticos na forma de representações gráficas fornecidas pelos aparelhos de detecção (comumente denominadas eletroferogramas), são utilizados softwares apropriados para a definição dos alelos obtidos para cada amostra através da comparação com as escadas alélicas. Após a análise visual e informatizada destes dados, ocorre a tabulação dos resultados para que possam ser submetidos posteriormente às análises estatísticas pertinentes a cada caso.

Para a maioria das análises de DNA envolvendo amostras forenses, há basicamente dois objetivos com relação à obtenção dos resultados: estabelecer se duas (ou mais) amostras pertencem a uma mesma pessoa (no caso de perfis genéticos coincidentes) ou a verificação da 
existência de vínculos genéticos entre amostras, na expectativa de, por exemplo, identificar indivíduos através de tais vínculos ou mesmo da averiguação do próprio vínculo, como nos casos de Testes de Paternidade. Cabe salientar, entretanto, que se tratam de análises comparativas, nas quais serão inferidas conclusões baseadas na análise conjunta das amostras questionadas e das amostras-referência.

Ao considerar a combinação entre o DNA proveniente, por exemplo, de uma amostra encontrada em local de crime e a de um suspeito, temos que levar em conta que se o perfil deste DNA for comum na população, o vestígio pode ter sido originado por outra pessoa que não o sujeito. Entretanto, se for incomum, a combinação entre os perfis certamente não terá sido mera coincidência, pois quanto mais raro for perfil, será menos provável que as duas amostras de DNA tenham vindo de pessoas diferentes (BONACCORSO, 2005). Estas análises estatísticas dependerão da realização de estudos populacionais que disponibilizem as frequências alélicas dos microssatélites na população analisada, na forma de bancos de dados de frequiências, que poderão ser prontamente utilizados no momento da realização dos cálculos (LINCOLN; THOMSON, 1998). Há que se considerar, entretanto, que tais bancos de dados necessitam ter um tamanho ideal, que seja representativo da população em estudo e devem ser também avaliados aspectos quanto a possível ocorrência de subestruturações populacionais que ocasionem distorções nos valores estatísticos obtidos, sendo que parâmetros de correção devem ser empregados (CONSELHO NACIONAL DE PESQUISA NRC, 1996).

A razão de verossimilhanças ( $\mathrm{LR}$ - likelihood ratio) é a relação entre a probabilidade de se obter uma identidade de perfis genéticos se o DNA na amostra questionada e o do suspeito vierem da mesma pessoa, e a probabilidade de uma identidade se os DNAs forem provenientes de pessoas diferentes (CONSELHO NACIONAL DE PESQUISA - NRC, 1996). O cálculo desta relação baseia-se em assumir que, se a população estiver em equilíbrio de Hardy-Weinberg, a proporção de indivíduos homozigotos para um dado alelo será o quadrado da freqüência deste alelo $\left(\mathrm{p}^{2}\right)$ e a proporção de indivíduos heterozigotos será o produto das duas freqüências multiplicado por dois $(2 \mathrm{pq})$. Considerando-se a ocorrência de Equilíbrio de Ligação para as regiões do DNA analisadas por determinado sistema (que presume que não existe correlação entre os genótipos em loci individuais), é possível calcularmos a frequiência de um dado genótipo na população através da regra do produto que é a multiplicação das frequiências dos genótipos de cada locus. A LR é a recíproca da probabilidade de combinação aleatória e um valor de 1000 significa que é 1000 vezes mais provável obter uma identidade dos perfis se as amostras do DNA tiverem vindo da mesma pessoa do que se elas se 
originaram de dois indivíduos quaisquer aleatoriamente escolhidos da população (CONSELHO NACIONAL DE PESQUISA - NRC, 1996).

Para os cálculos de vínculos genéticos, seja para a identificação de cadáveres, seja para testes de paternidade (ou outros parentescos), também são utilizados os bancos de dados de frequiências populacionais, são considerados os mesmos postulados da Lei de HardyWeinberg, aliados ao Teorema de Bayes que confere certo grau de subjetividade na forma da probabilidade a priori (que por si só desconsidera os dados obtidos a partir das evidências genéticas) fornecendo resultados na forma de uma probabilidade a posteriori. Nestes casos são calculados índices de paternidade (IP), índice de paternidade cumulativo (IPC) e a probabilidade de paternidade (PP) ou outros parentescos.

Há ainda cálculos próprios para os casos em que observa a presença de misturas de perfis genéticos, de maior complexidade e que fornecem como resultado a chance daquele perfil genético ter sido gerado por diferentes indivíduos contribuintes. (WEIR et al., 1997).

\subsection{Bancos de dados de perfis genéticos}

No relatório do NRC de 1992 (CONSELHO NACIONAL DE PESQUISA - NRC, 1992), sigilo e segurança da informação relacionada ao DNA são questões particularmente importantes e difíceis, já que a sociedade atual vivencia duas extraordinárias revoluções tecnológicas: na biologia molecular, que está promovendo uma explosão de informações sobre genética humana, e na tecnologia dos computadores, que está criando redes nacionais e internacionais para conectar um volume cada vez maior de informações. Apesar de terem se passado aproximadamente 15 anos da emissão do referido relatório, seu texto permanece fiel já que continuamos ainda com avanços científico-tecnológicos desenfreados.

Os bancos de dados de DNA são aqueles em que as informações genéticas são armazenadas para fins de identificação de um indivíduo por comparação com o padrão armazenado (GOLDIM; MATTE, 1999). Estes bancos podem ser utilizados tanto na esfera criminal quanto na esfera cível. Países como EUA, Inglaterra, Canadá, Alemanha, França, Austrália a Nova Zelândia já desenvolveram bancos de dados de DNA criminais (CHEMELLO, 2007). Dependendo da situação, estas bases de dados forenses podem conter informações genéticas de condenados somente, ou de condenados e investigados ou até incluir todos os suspeitos durante o processo. As legislações de cada país estabelecem quais 
crimes são passíveis de inserção no banco, além de outros critérios com relação ao tempo de permanência destas informações.

É necessário, portanto, que toda a criação e a manipulação dos dados contidos nos bancos de dados de perfis genéticos sejam criteriosamente e eticamente regulamentadas, o que ainda está por vir no Brasil, diferentemente de outros países estrangeiros, como, por exemplo, os Estados Unidos que já o fizeram e que utilizam rotineiramente seu banco de dados de perfis genéticos durante as investigações criminais. Será fundamental regulamentar e controlar, com relação aos bancos de dados que serão aqui futuramente implantados, parâmetros de acesso, de inclusão, manipulação e remoção de tais dados do sistema, bem como os pré-requisitos a serem cumpridos de modo que uma dada amostra ou pessoa tenha seu perfil genético inserido neste tipo de banco. Será necessário definir se somente indivíduos já julgados e condenados, ou até mesmo os que forem simplesmente detidos terão suas amostras coletadas (por quem e de que forma), analisadas e inseridas no sistema. Ainda serão feitas opções sobre a intercambialidade dos dados, entre diferentes cidades, estados e até países.

Outro impacto social importante causado pela introdução de novas e poderosas tecnologias, como foi o caso da tipagem de DNA, é a criação de expectativas injustificadas ou irreais sobre elas, principalmente por força da mídia, sendo necessário desmistificar e situar as reais limitações da técnica (BONACCORSO, 2005). Muitas vezes são solicitados aos laboratórios exames de DNA cuja real necessidade é duvidosa, pois outros elementos da investigação e outras metodologias mais simples e menos custosas já seriam capazes de resolver o caso.

Nos Estados Unidos, o FBI implantou em 1998 o CODIS (Combined DNA Index System), um conjunto de treze marcadores do tipo STR (recomendáveis para identificação humana por análise de DNA), que vem sendo amplamente utilizado e a partir do qual foram modelados diversos reagentes comerciais próprios para a amplificação de marcadores microssatélites. O CODIS contém perfis genéticos de indivíduos condenados e os resultados de buscas em sua base de dados têm facilitado sobremaneira as investigações criminais. Os principais kits comerciais para a análise de STRs contemplam estas 13 regiões e mais algumas outras.

Entretanto, existem algumas situações em que se torna necessário o estudo de outras regiões do DNA, ou seja, situações em que se precisa aumentar o painel de loci analisados. Em casos de desastres de massa, por exemplo, quando as amostras analisadas encontram-se extremamente degradadas, o uso de miniSTRs pode ser bastante útil na identificação quando 
somente foram obtidos perfis genéticos parciais nos tradicionais loci pertencentes ao CODIS, presentes nos kits comerciais mais utilizados. Mesmo quando um perfil completo é conseguido nesses casos, pode ocorrer de haver um número insuficiente de amostrasreferência de familiares da vítima que permitam uma identificação com alto grau de confiabilidade. Também não podem ser ignorados os casos de tentativa de estabelecimento de vínculo genético familiar em que são observadas mutações e que requerem análises adicionais para a confirmação dos achados e as situações em que são observadas misturas de materiais biológicos de diferentes pessoas. Por fim, mas não menos comuns na realidade das análises forenses, há os casos de testes de paternidade complexos oriundos de relações familiares incestuosas e que devido ao alto grau de consangüinidade e vínculo de parentesco entre os envolvidos necessitam da análise de regiões do DNA adicionais em comparação com os testes rotineiros (GOODWIN et al., 2004; COBLE; BUTLER, 2005).

Desta forma, vem sendo gradualmente introduzidos na comunidade para identificação humana por análise de DNA os chamados loci "non-CODIS" (COBLE et al., 2006; GILL et al., 2006) e quando possível, estes tem sido desenvolvidos no formato de miniSTRs.

\subsection{Microssatélites utilizados neste estudo}

Neste trabalho foram pesquisadas 6 regiões polimórficas do DNA humano, microssatélites (STR), sendo 5 de repetições de tetranucleotídeos D1S1677, D2S441, D4S2364, D10S1248 e D14S1434 e 1 trinucleotídeo D22S1045 e que são conhecidos por STRs “non-CODIS”, já que não fazem parte do banco de dados CODIS.

Estes microssatélites foram selecionados pelo fato de existirem publicações internacionais relatando seu emprego em análises forenses de DNA, sem ainda haver disponíveis estudos quanto à sua utilização na população e laboratórios brasileiros.

A nomenclatura destes loci polimórficos segue o critério de localização cromossômica (BUTLER, 2005) e, a título de exemplo, segue abaixo o significado de cada componente do nome do locus D1S1677 (o mesmo raciocínio se aplica aos outros 5 STRs analisados):

- D: refere-se à molécula de DNA;

- 1: cromossomo 1;

- S: sequência de cópia única (single copy sequence) 
- 1677: indica a ordem em que o marcador foi descoberto e caracterizado no referido cromossomo; foi $1677^{\circ}$ polimorfismo caracterizado no cromossomo 1 .

\subsubsection{Microssatélite D1S1677}

O locus D1S1677 está localizado no braço longo do cromossomo 1 (1q23.3) e a sequência repetitiva corresponde ao tetranucleotídeo $(\mathrm{GGAA})_{\mathrm{n}}$. Os esquemas que ilustram a localização cromossômica e a sequência da região polimórfica encontram-se na Figura 3.

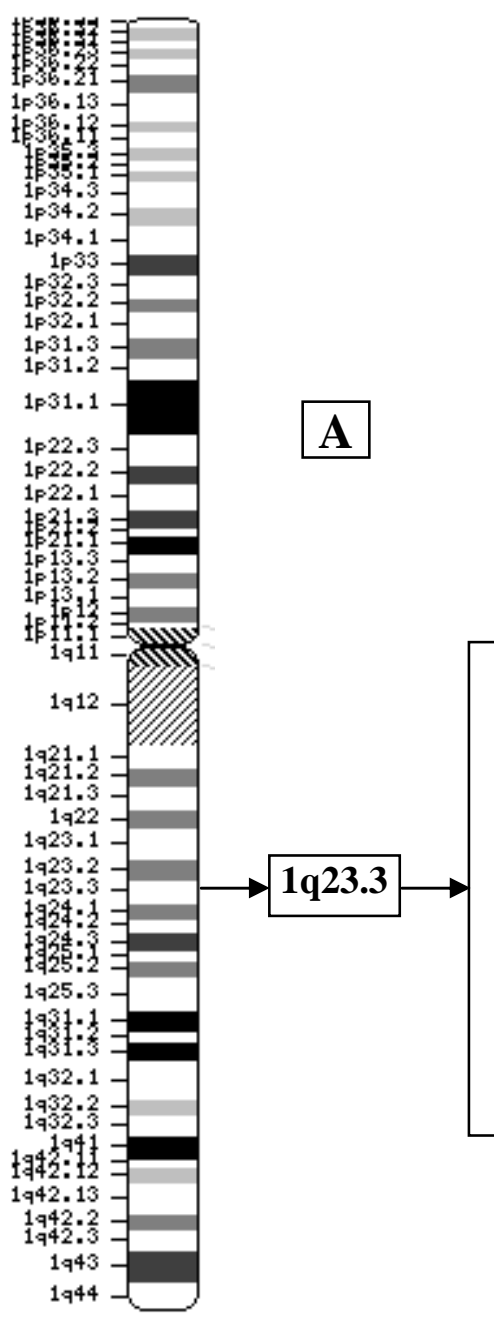

NCBI Reference Sequence: NW_926128.1 - Homo sapiens chromosome 1 genomic contig, alternate assembly (based on Celera), whole genome shotgun sequence AATTGTATTTCTTAGTGTGACAGGAAGGACGGAATGAAGGAAGGAA GGAAGGAAGGAAGGAAGGAAGGAAGGAAGGAAGGAAGGAAGG AAGGAAGGAAACACTGCTCTATACCAACAGAAAAACTGTAGCTATA CAATTACGCTGCACCAGCACTACAGTGGGTTGTTGCTTCCAGTAAAG CTCCTGACTATACTGGATCAATCAAGCTGACTGCCTCAGCCAA

Figura 3 - A - Localização do microssatélite D1S1677 em representação esquemática do cromossomo 1 humano. B - Número da sequência de referência, nome do arquivo e sequência da região polimórfica encontrados no banco de dados GenBank, disponibilizado na página da Internet "NCBI: Entrez Nucleotide" (GENBANK, 2010). Encontram-se destacadas em amarelo a posição de ligação dos primers utilizados neste estudo e sublinhada sequência polimórfica. 
1.6.2 Microssatélite D2S441

O locus D2S441 está localizado no braço curto do cromossomo 2 (2p14) e a sequência repetitiva corresponde a (TCTA) $)_{n}$. Os esquemas que ilustram a localização cromossômica e a sequência da região polimórfica encontram-se na Figura 4.

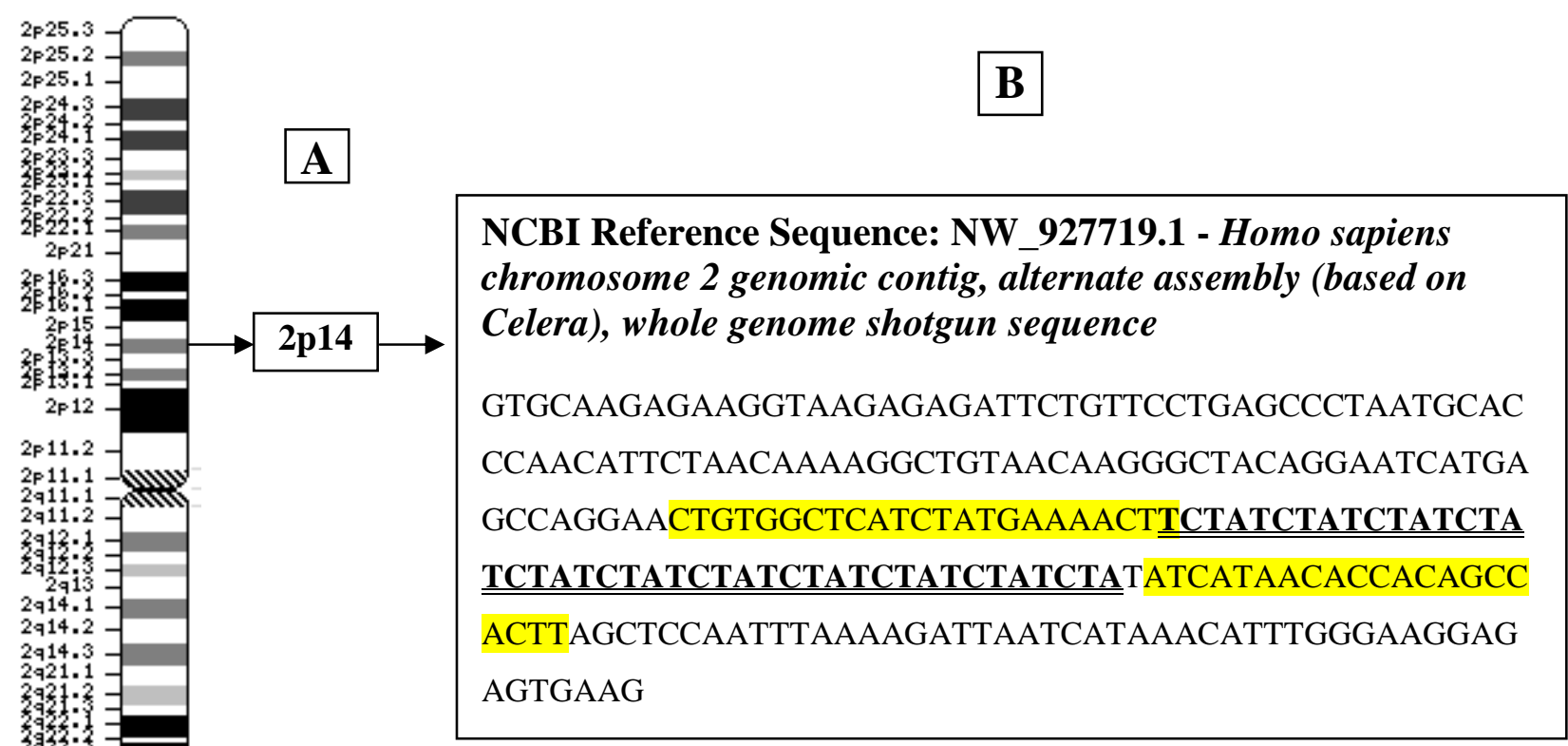

Figura 4 - A - Localização do microssatélite D2S441 em representação esquemática do cromossomo 2 humano. B - Número da sequência de referência, nome do arquivo e sequência da região polimórfica encontrados no banco de dados GenBank, disponibilizado na página da Internet "NCBI: Entrez Nucleotide" (GENBANK, 2010). Encontram-se destacadas em amarelo a posição de ligação dos primers utilizados neste estudo e sublinhada sequência polimórfica. 


\subsubsection{Microssatélite D4S2364}

O locus D4S2364 está localizado no braço longo do cromossomo 4 (4q22.3) e a sequência repetitiva corresponde ao tetranucleotídeo complexo (GAAT)(GGAT)(GAAT)n. Os esquemas que ilustram a localização cromossômica e a sequência da região polimórfica encontram-se na Figura 5.

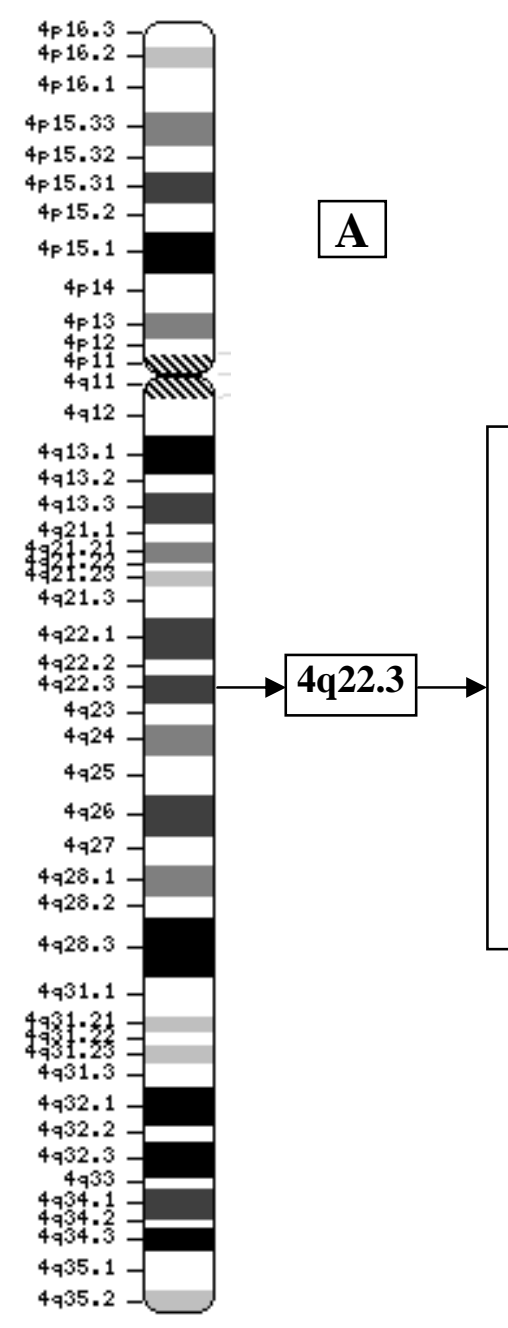

\section{B}

NCBI Reference Sequence: NW_922162.1 - Homo sapiens chromosome 4 genomic contig, alternate assembly (based on Celera), whole genome shotgun sequence

AGCACTGGGATAGACATTGAGACTCAAGGCACAACCTTGACTTTGA

TGTGGGAAGGAAAGTAGGAATGAAAACAGTGAATAAATGAACGAA

TGGATGAATGAATGAATGAATGAATGAATGAATAGAATCATACCC ACATGATCTCCTAGTTTTGTTTCTCAGCTCCTACAGACAACAATTCTC AAGTTTA

Figura 5 - A - Localização do microssatélite D4S2364 em representação esquemática do cromossomo 4 humano. B - Número da sequência de referência, nome do arquivo e sequência da região polimórfica encontrados no banco de dados GenBank, disponibilizado na página da Internet "NCBI: Entrez Nucleotide" (GENBANK, 2010). Encontram-se destacadas em amarelo a posição de ligação dos primers utilizados neste estudo e sublinhada sequência polimórfica. 
1.6.4 Microssatélite D10S1248

O locus D10S1248 está localizado no braço longo do cromossomo 10 (10q26.3) e a sequência repetitiva corresponde ao tetranucleotídeo $(\mathrm{GGAA})_{\mathrm{n}}$. Os esquemas que ilustram a localização cromossômica e a sequência da região polimórfica encontram-se na Figura 6.

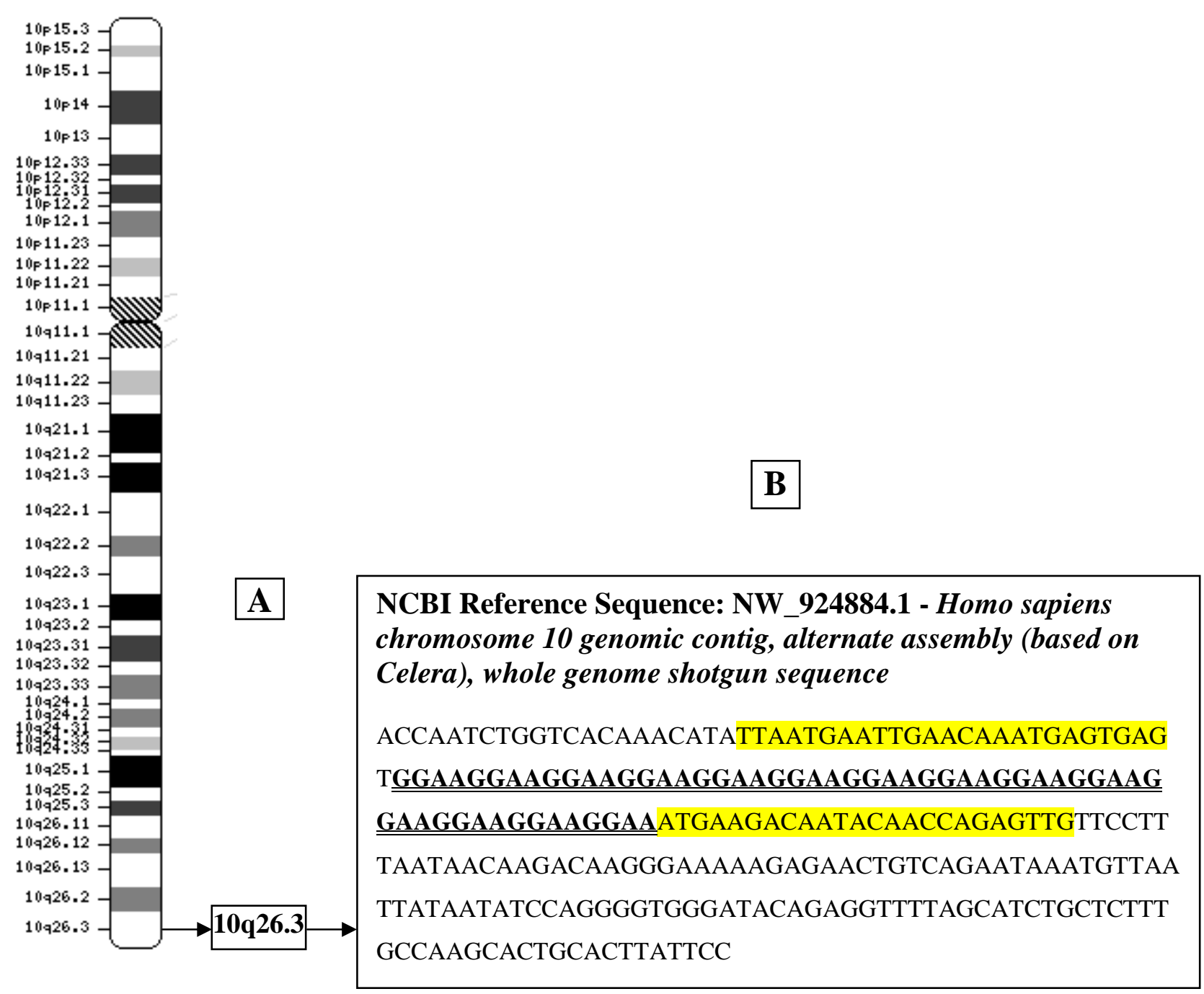

Figura 6 - A - Localização do microssatélite D10S1248 em representação esquemática do cromossomo 10 humano. B - Número da sequência de referência, nome do arquivo e sequência da região polimórfica encontrados no banco de dados GenBank, disponibilizado na página da Internet "NCBI: Entrez Nucleotide" (GENBANK, 2010). Encontram-se destacadas em amarelo a posição de ligação dos primers utilizados neste estudo e sublinhada sequência polimórfica. 
1.6.5 Microssatélite D14S1434

O locus D14S1434 está localizado no braço longo do cromossomo 14 (14q32.13) e a sequência repetitiva corresponde ao tetranucleotídeo complexo (GATA) n $($ GACA) . Os esquemas que ilustram a localização cromossômica e a sequência da região polimórfica encontram-se na Figura 7.

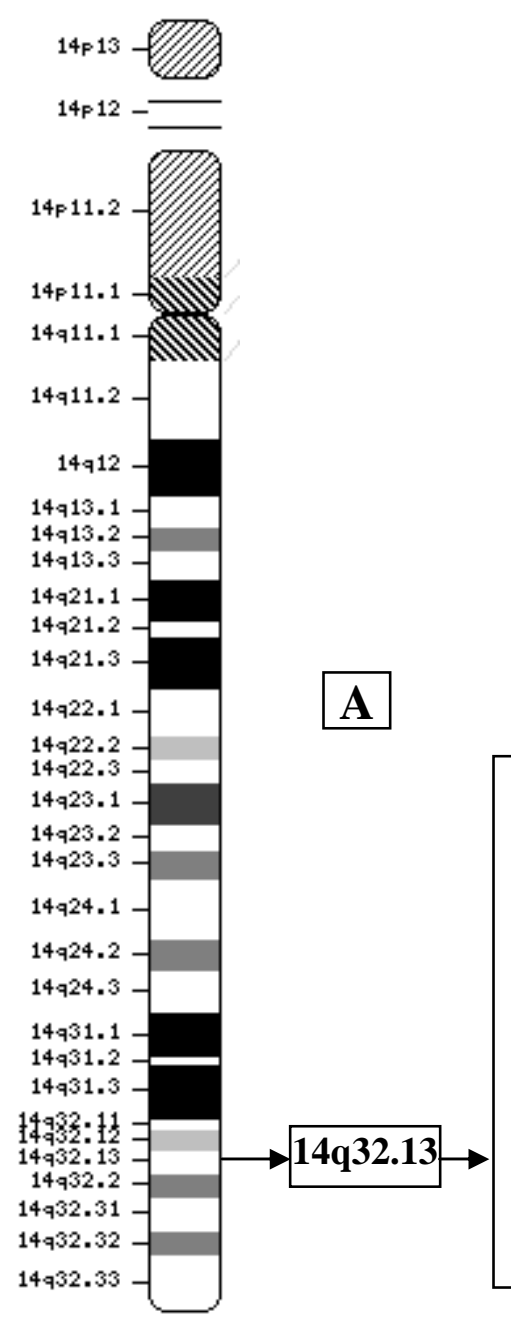

NCBI Reference Sequence: NW_925561.1 - Homo sapiens chromosome 14 genomic contig, alternate assembly (based on Celera), whole genome shotgun sequence

ACAATTCCAGAAACTTCCCCAACTCTTGGAAGCCCAGTCAAGGACCC CTGGTTCCATGGATTCCACATTAAGAGCTCTGGCTCCGGAGCAGTGG TTTAAAAAATAACTGTAGAACCAATAGGAGGTGGATGGATG $\underline{\underline{\text { GATAG }}}$ ATAGATAGATAGATAGATAGATAGATAGATAGATAGACAGACAG ACAGTCGTAGAGTTATTACAAGGAATTGGCTCACTGAT

Figura 7 - A - Localização do microssatélite D14S1434 em representação esquemática do cromossomo 14 humano. B - Número da sequência de referência, nome do arquivo e sequência da região polimórfica encontrados no banco de dados GenBank, disponibilizado na página da Internet "NCBI: Entrez Nucleotide" (GENBANK, 2010) Encontram-se destacadas em amarelo a posição de ligação dos primers utilizados neste estudo e sublinhada sequência polimórfica. 
1.6.6 Microssatélite D22S1045

O locus D22S1045 está localizado no braço longo do cromossomo 22 (22q12.3) e a sequência repetitiva corresponde ao trinucleotídeo (TAA)n. Os esquemas que ilustram a localização cromossômica e a sequência da região polimórfica encontram-se na Figura 8.

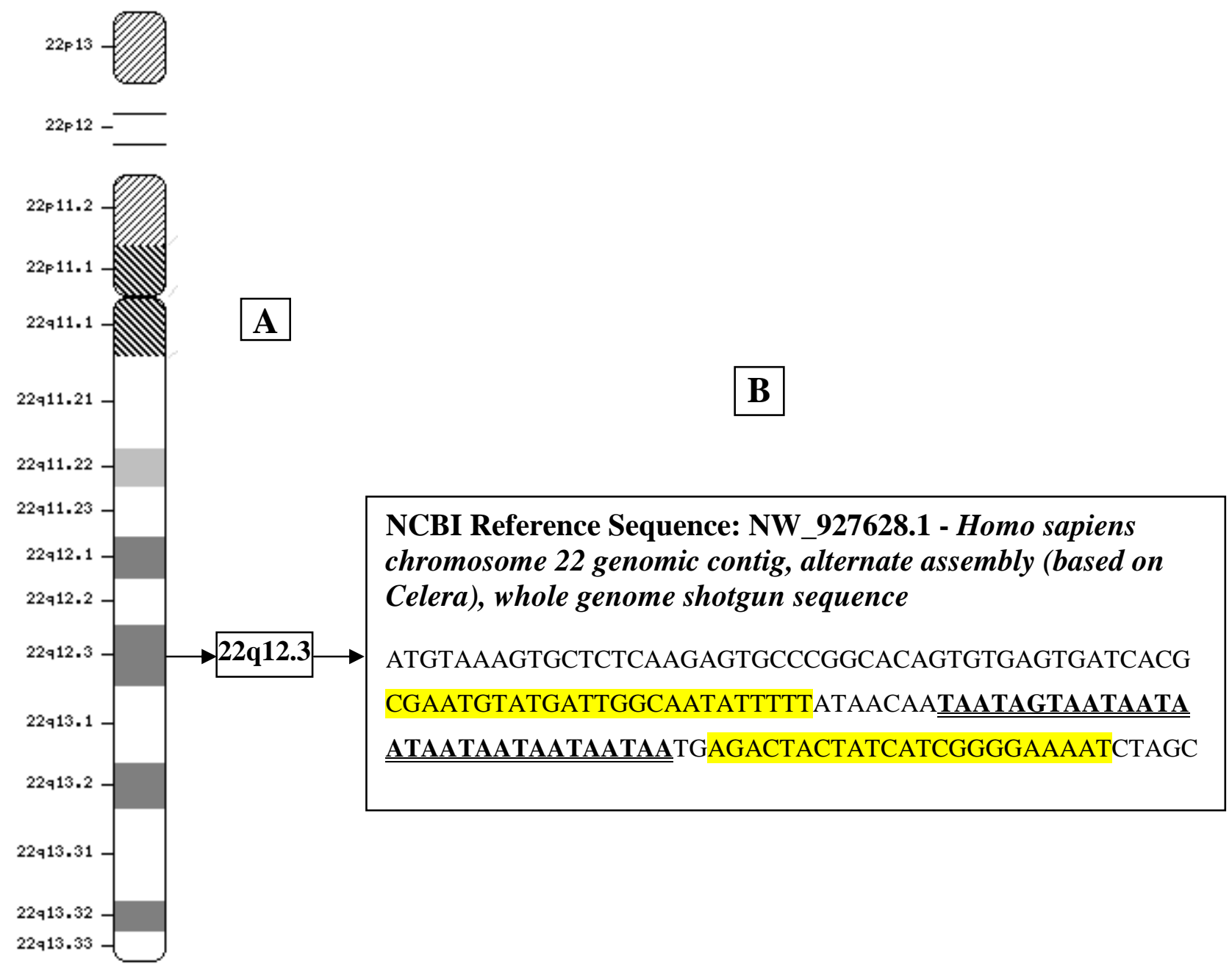

Figura 8 - A - Localização do microssatélite D22S1045 em representação esquemática do cromossomo 22 humano. B - Número da sequência de referência, nome do arquivo e sequência da região polimórfica encontrados no banco de dados GenBank, disponibilizado na página da Internet "NCBI: Entrez Nucleotide" (GENBANK, 2010). Encontram-se destacadas em amarelo a posição de ligação dos primers utilizados neste estudo e sublinhada sequência polimórfica. 
2 OBJETIVOS 
2.1 Padronizar as reações para amplificação das regiões do DNA dos microssatélites D1S1677, D2S441, D4S2364, D10S1248, D14S1434 e D22S1045, que não fazem parte do sistema CODIS (são STRs “non-CODIS"), no formato de miniSTRs e em duas reações do tipo multiplex;

2.2 Avaliar nestas reações amostras de casos forenses, com DNA extraído de diferentes amostras biológicas como ossos, dentes, materiais de crimes sexuais e vestígios biológicos humanos provenientes de locais de crimes;

2.3 Avaliar os parâmetros de sensibilidade, conservação das amostras e a respectiva qualidade dos perfis genéticos obtidos para cada um destes loci polimórficos;

2.4 Estabelecer considerações sobre as vantagens e desvantagens do uso destes sistemas na rotina em biologia forense. 
3 CASUÍSTICA, MATERIAIS E MÉTODOS 


\subsection{Casuística}

Foram estudados materiais referentes a 53 casos de análise de DNA forense criminal, recebidos para perícia ao longo do ano de 2009 pelo Laboratório de DNA do Instituto de Criminalística do Estado de São Paulo, e atribuídos à perita criminal autora deste trabalho. Entre os 53 casos, 19 objetivavam identificação de cadáveres, 16 eram correspondentes a crimes sexuais e os 18 restantes envolviam a análise de vestígios biológicos oriundos de locais de crimes. No total, foram avaliadas 80 amostras de DNA extraídos, sendo 71 amostras-questionadas e 09 amostras-referência de vítimas, suspeitos ou familiares relacionados.

Durante o estudo, as amostras tiveram sua identificação original descaracterizada, sendo mantido o sigilo necessário a esta situação e aos resultados obtidos, de acordo com o preconizado pela comissão de ética em pesquisa e o parecer emitido pelo Centro de Exames, Análises e Pesquisas (CEAP), do Instituto de Criminalística (ANEXO B). Para as amostrasreferência, fornecidas por indivíduos vivos (vítimas, suspeitos ou familiares relacionados), lavrou-se um Termo de Consentimento Livre e Esclarecido, cujo modelo pode ser visualizado no Anexo C, nos moldes do recomendado na Resolução SSP nº 194/99 (ANEXO A).

\subsection{Materiais}

Foram analisados materiais biológicos de origem humana, de diferentes fontes e dispostos em vários tipos de suportes físicos. Na classificação dos materiais, foram considerados, quando havia informações disponíveis na documentação recebida juntamente com os respectivos casos, os seguintes critérios:

- tipo de caso;

- tipo de material;

- tempo decorrido após o óbito ou após o crime até o recebimento no laboratório, baseado em dados concretos ou em estimativas por parte dos médicos legistas ou peritos criminais responsáveis pela coleta no local do crime;

- condições de conservação do material no período antes do seu recebimento no laboratório, de acordo com informações e/ou estimativas;

- grau de carbonização, quando aplicável. 
As tabelas a seguir classificam os materiais analisados, de acordo com os critérios acima estabelecidos.

Tabela 1 - Casos envolvendo Identificação de Cadáveres.

\begin{tabular}{l|cccc}
\hline Caso & Material biológico & $\begin{array}{c}\text { Tempo após } \\
\text { o óbito/crime } \\
\text { (em dias) }\end{array}$ & Conservação & Carbonização \\
\hline 01 & Sangue coletado de cadáver & 10 & 4 a $8^{\circ} \mathrm{C}$ & Sim \\
02 & Osso esterno & 285 & 4 a $8{ }^{\circ} \mathrm{C}$ & Não \\
03 & Osso fêmur & 282 & temp. ambiente & Não \\
04 & Osso fêmur & 1314 & exumação & Não \\
05 & Osso fêmur & 1798 & fossa asséptica & Não \\
06 & Ossada de recém-nascido & 2578 & exumação & Não \\
07 & Osso fêmur & 28 & temp. ambiente & Não \\
08 & Sangue coletado de cadáver & 31 & temp. ambiente & Sim \\
09 & Dentes & 96 & 4 a $8^{\circ} \mathrm{C}$ & Não \\
10 & Osso fêmur & 360 & 4 a $8{ }^{\circ} \mathrm{C}$ & Sim \\
11 & Osso fêmur & 74 & 4 a $8{ }^{\circ} \mathrm{C}$ & Não \\
12 & Osso fêmur & 2577 & 4 a $8^{\circ} \mathrm{C}$ & Não \\
13 & Osso fêmur & 2306 & exumação & Não \\
14 & Osso úmero & 111 & 4 a $8{ }^{\circ} \mathrm{C}$ & Não \\
15 & Músculo cardíaco de feto & 111 & $-20^{\circ} \mathrm{C}$ & Não \\
16 & Músculo da perna de cadáver & 269 & 4 a $8{ }^{\circ} \mathrm{C}$ & Sim \\
17 & Osso fêmur & 496 & $-20^{\circ} \mathrm{C}$ & Não \\
18 & Osso fêmur & 21 & 4 a $8{ }^{\circ} \mathrm{C}$ & Sim \\
19 & Osso fêmur & & Não \\
\hline
\end{tabular}

temp. ambiente, temperatura ambiente. 
Tabela 2 - Casos envolvendo Crimes Sexuais.

\begin{tabular}{c|ccc}
\hline Caso & Material biológico & $\begin{array}{c}\text { Tempo após o } \\
\text { óbito/crime } \\
\text { (em dias) }\end{array}$ & Conservação \\
\hline 20 & $\begin{array}{c}\text { Swab vaginal } \\
21\end{array}$ & 186 & 4 a $8^{\circ} \mathrm{C}$ \\
& Fragmento de lençol com supostas manchas & 249 & $-20{ }^{\circ} \mathrm{C}$ \\
22 & Pe sêmen & 1575 & temp. \\
23 & Papel de filtro contendo secreção vaginal & 5 & Ambiente \\
24 & Swab vaginal & 39 & 4 a $8{ }^{\circ} \mathrm{C}$ \\
25 & Conteúdo uterino em caso de aborto & 48 & 4 a $8{ }^{\circ} \mathrm{C}$ \\
26 & Swab vaginal & 175 & 4 a $8{ }^{\circ} \mathrm{C}$ \\
27 & Calcinha com manchas de sêmen & 4 & 4 a $8{ }^{\circ} \mathrm{C}$ \\
28 & Espátula contendo secreção vaginal & 20 & 4 a $8{ }^{\circ} \mathrm{C}$ \\
29 & Swab anal & 225 & 4 a $8{ }^{\circ} \mathrm{C}$ \\
30 & Swab anal & 73 & 4 a $8{ }^{\circ} \mathrm{C}$ \\
31 & Urina e sondas uretrais & 24 & 4 a $8{ }^{\circ} \mathrm{C}$ \\
32 & Cuecas contendo manchas de sêmen & 173 & temp. ambiente \\
33 & Swab anal & 73 & 4 a $8{ }^{\circ} \mathrm{C}$ \\
34 & Sangue de trio de paternidade pós-estupro & 1 & 4 a $8{ }^{\circ} \mathrm{C}$ \\
35 & Sangue de trio de paternidade pós-estupro & 1 & 4 a $8{ }^{\circ} \mathrm{C}$ \\
\hline
\end{tabular}

Tabela 3 - Casos envolvendo análise de vestígios biológicos oriundos de locais de crimes.

(continua)

\begin{tabular}{|c|c|c|c|}
\hline Caso & Material biológico & $\begin{array}{c}\text { Tempo após o } \\
\text { óbito/crime } \\
\text { (em dias) }\end{array}$ & Conservação \\
\hline 36 & $\begin{array}{l}\text { Fragmento de camiseta com manchas de } \\
\text { sangue }\end{array}$ & 7 & temp. ambiente \\
\hline 37 & $\begin{array}{l}\text { Assento de veículo com supostas manchas } \\
\text { de sangue }\end{array}$ & 14 & temp. ambiente \\
\hline 38 & $\begin{array}{c}\text { Material subungueal e ossos da mão da } \\
\text { vítima }\end{array}$ & 44 & 4 a $8^{\circ} \mathrm{C}$ \\
\hline 39 & $\begin{array}{l}\text { Coágulos de sangue coletados em piso e } \\
\text { porta }\end{array}$ & 14 & temp. ambiente \\
\hline 40 & Lâmina contendo secreção nasal & 70 & temp. ambiente \\
\hline 41 & $\begin{array}{c}\text { Camiseta com manchas de sangue e sangue } \\
\text { coletado de cadáver }\end{array}$ & 01 & $\begin{array}{l}\text { temp. ambiente } \\
\text { e } 4 \text { a } 8^{\circ} \mathrm{C}\end{array}$ \\
\hline 42 & $\begin{array}{c}\text { Óculos de sol com eventuais células de } \\
\text { descamação }\end{array}$ & 21 & temp. ambiente \\
\hline 43 & $\begin{array}{l}\text { Material subungueal e sangue coletado de } \\
\text { cadáveres }\end{array}$ & 03 & 4 a $8^{\circ} \mathrm{C}$ \\
\hline
\end{tabular}


Tabela 3 - Casos envolvendo análise de vestígios biológicos oriundos de locais de crimes.

(conclusão)

\begin{tabular}{|c|c|c|c|}
\hline Caso & Material biológico & $\begin{array}{c}\text { Tempo após o } \\
\text { óbito/crime } \\
\text { (em dias) }\end{array}$ & Conservação \\
\hline 44 & $\begin{array}{l}\text { Estofamento e tapete de borracha de veículo } \\
\text { com supostas manchas de sangue }\end{array}$ & 19 & temp. ambiente \\
\hline 45 & Mancha de sangue coletada de veículo & 1205 & 4 a $8^{\circ} \mathrm{C}$ \\
\hline 46 & $\begin{array}{c}\text { Brinco, bojo de sutiã e cueca com manchas } \\
\text { de sangue }\end{array}$ & 32 & temp. ambiente \\
\hline 47 & Mancha de sangue coletada de veículo & 49 & temp. ambiente \\
\hline 48 & Fragmento de vidro com mancha de sangue & 06 & temp. ambiente \\
\hline 49 & Gazes contendo manchas de sangue & 236 & $-20^{\circ} \mathrm{C}$ \\
\hline 50 & $\begin{array}{c}\text { Preservativo íntimo e vestuário feminino } \\
\text { com manchas de sêmen }\end{array}$ & 14 & temp. ambiente \\
\hline 51 & $\begin{array}{c}\text { Bermuda com manchas de sangue e sangue } \\
\text { dos supostos familiares }\end{array}$ & 94 & $\begin{array}{l}\text { temp. ambiente } \\
\text { e } 4 \text { a } 8^{\circ} \mathrm{C}\end{array}$ \\
\hline 52 & $\begin{array}{c}\text { Bituca de cigarro com células de } \\
\text { descamação }\end{array}$ & 47 & temp. ambiente \\
\hline 53 & Swab bucal com células epiteliais & 05 & temp. ambiente \\
\hline
\end{tabular}

\subsection{Métodos}

\subsubsection{Extração de DNA}

A extração do DNA para cada tipo de material biológico obedeceu aos diversos protocolos já previamente estabelecidos e em uso rotineiro no Laboratório de DNA do Instituto de Criminalística do Estado de São Paulo, e que se encontram detalhados no Apêndice A. Para as amostras ósseas, dentárias e musculares referentes aos casos de identificação de cadáveres foi empregada a extração orgânica de DNA (MANIATIS; SAMBROOK; FRITSCH, 1996), com modificações e adaptações pertinentes ao tipo de amostra.

Nos casos envolvendo crimes sexuais, quando se analisam materiais que contêm mistura de células epiteliais femininas e espermatozoides do agressor, a metodologia de extração de eleição é a extração orgânica diferencial de DNA (GILL; JEFFREYS; WERRET, 1985), que possibilita a separação das células femininas e masculinas baseando-se na diferente resistência das respectivas membranas celulares e o uso criterioso e controlado de reagentes específicos em fases e concentrações diferentes ao longo do processo. Nestes 
mesmos casos, também se aplica a extração direta de DNA, sem discriminação sexual, utilizando-se principalmente resinas magnéticas e/ou quelantes (WALSH; METZGER; HIGUCHI, 1991).

Essas resinas são comumente empregadas nos casos de análises de vestígios biológicos em geral, oriundos de locais de crime e dispostos em diferentes tipos de suporte, sendo que a extração pode ser realizada tanto a partir de um próprio pedaço do suporte contendo o material biológico, como também através da transferência do material para um swab de algodão e posterior extração de seu conteúdo.

A tabela abaixo detalha todas as 80 amostras que foram analisadas e o método de extração de DNA empregado (Tabela 4).

As amostras selecionadas para este estudo compreenderam os melhores exemplares de DNA extraídos durante as análises de cada caso ao longo do ano de 2009, não sendo incluídas nesta pesquisa todas as repetições de tentativas de extração de cada uma das amostras.

Tabela 4 - Identificação dos materiais e respectivo método de extração de DNA.

(continua)

\begin{tabular}{|c|c|c|}
\hline Caso & Identificação do material & Método de extração de DNA \\
\hline & A-Sangue coletado de cadáver & Resina magnética* \\
\hline 01 & B-Sangue coletado de cadáver & Resina quelante ${ }^{* *}$ \\
\hline 02 & Osso esterno & Orgânica com purificação em coluna*** \\
\hline $\mathbf{0 3}$ & Osso fêmur & Orgânica com purificação em coluna*** \\
\hline 04 & Osso fêmur & $\begin{array}{l}\text { Orgânica com purificação com resina } \\
\text { magnética* }\end{array}$ \\
\hline 05 & Osso fêmur & Orgânica com purificação em coluna*** \\
\hline 06 & Ossada de recém-nascido & Orgânica com purificação em coluna*** \\
\hline 07 & Osso fêmur & Orgânica com precipitação por álcool \\
\hline 08 & Sangue de cadáver & Resina magnética* \\
\hline 09 & Dentes & Orgânica com precipitação por álcool \\
\hline 10 & Osso fêmur & Orgânica com precipitação por álcool \\
\hline 11 & Osso fêmur & Orgânica com precipitação por álcool \\
\hline 12 & Osso fêmur & Orgânica com precipitação por álcool \\
\hline 13 & Osso fêmur & Orgânica com precipitação por álcool \\
\hline 14 & Osso úmero & $\begin{array}{l}\text { Orgânica com precipitação por álcool e } \\
\text { purificação com resina magnética* }\end{array}$ \\
\hline 15 & Músculo cardíaco de feto & Orgânica com precipitação por álcool \\
\hline 16 & Músculo de cadáver & Orgânica com precipitação por álcool \\
\hline 17 & Osso fêmur & Orgânica com precipitação por álcool \\
\hline 18 & Osso fêmur & Orgânica com precipitação por álcool \\
\hline 19 & Osso fêmur & Orgânica com precipitação por álcool \\
\hline 20 & $\begin{array}{c}\text { A-Swab vaginal-FE } \\
\text { B-Swab vaginal-FNE }\end{array}$ & A e B-Orgânica diferencial \\
\hline 21 & $\begin{array}{l}\text { Fragmento de lençol com supostas manchas } \\
\text { de sêmen }\end{array}$ & Resina magnética* \\
\hline
\end{tabular}


Tabela 4 - Identificação dos materiais e respectivo método de extração de DNA.

(continuação)

\begin{tabular}{|c|c|c|}
\hline Caso & Identificação do material & Método de extração de DNA \\
\hline 22 & $\begin{array}{l}\text { A-Papel de filtro com secreção vaginal-FE } \\
\text { B-Papel de filtro com secreção vaginal-FNE }\end{array}$ & A e B-Orgânica diferencial \\
\hline 23 & $\begin{array}{c}\text { A-Swab vaginal } \\
\text { B-Swab vaginal-FE } \\
\text { C-Swab vaginal-FNE }\end{array}$ & $\begin{array}{l}\text { A-Resina magnética* } \\
\text { B e C-Orgânica diferencial }\end{array}$ \\
\hline 24 & $\begin{array}{c}\text { A-Osso fêmur de feto } \\
\text { B-Sangue coletado do suposto pai }\end{array}$ & $\begin{array}{c}\text { A-Orgânica com precipitação por álcool } \\
\text { B-Resina magnética* }\end{array}$ \\
\hline 25 & Conteúdo uterino em caso de aborto & Orgânica com precipitação por álcool \\
\hline 26 & $S w a b$ vaginal & Resina magnética* \\
\hline 27 & Calcinha com manchas de sêmen & Resina magnética* \\
\hline 28 & $\begin{array}{c}\text { Espátula de madeira contendo secreção } \\
\text { vaginal }\end{array}$ & Orgânica com precipitação por álcool \\
\hline 29 & $\begin{array}{c}\text { A-Swab anal-FE } \\
\text { B-Swab anal-FNE }\end{array}$ & A e B-Orgânica diferencial \\
\hline 30 & $\begin{array}{l}\text { A-Swab anal-FE } \\
\text { B-Swab anal-FNE }\end{array}$ & A e B-Orgânica diferencial \\
\hline 31 & $\begin{array}{c}\text { A-Urina } \\
\text { B-Sondas uretrais } \\
\text { Cuecas contendo manchas de sêmen }\end{array}$ & $\begin{array}{c}\text { A-Orgânica com precipitação por álcool } \\
\text { B-Resina magnética* }\end{array}$ \\
\hline 32 & $\begin{array}{l}\text { A-Cueca } 1 \\
\text { B-Cueca } 2\end{array}$ & A e B-Resina magnética* \\
\hline 33 & $\begin{array}{l}\text { A-Sangue coletado de suspeito de estupro } \\
\text { B-Sangue coletado de suspeito de estupro } \\
\text { Sangue de trio de paternidade pós-estupro }\end{array}$ & A e B-Resina magnética* \\
\hline 34 & $\begin{array}{c}\text { A-Sangue coletado da mãe-vítima } \\
\text { B-Sangue da criança } \\
\text { C-Sangue do suposto pai }\end{array}$ & A, B e C-Resina quelante $* *$ \\
\hline 35 & $\begin{array}{c}\text { Sangue de trio de paternidade pós-estupro } \\
\text { A-Sangue coletado da mãe-vítima } \\
\text { B-Sangue da criança } \\
\text { C-Sangue do suposto pai }\end{array}$ & A, B e C-Resina quelante** \\
\hline 36 & $\begin{array}{l}\text { Fragmento de camiseta com manchas de } \\
\text { sangue }\end{array}$ & Orgânica com purificação em coluna*** \\
\hline 37 & $\begin{array}{l}\text { Assento de veículo com supostas manchas } \\
\text { de sangue }\end{array}$ & Resina magnética* \\
\hline 38 & $\begin{array}{l}\text { A-Material subungueal } \\
\text { B-Ossos da mão da vítima }\end{array}$ & $\begin{array}{c}\text { A-Resina magnética* } \\
\text { B-Orgânica com precipitação por álcool }\end{array}$ \\
\hline 39 & $\begin{array}{l}\text { A-Coágulos de sangue coletados em piso } \\
\text { B-Coágulos de sangue coletados em porta }\end{array}$ & A e B-Resina magnética* \\
\hline 40 & Lâmina contendo secreção nasal & Orgânica com purificação em coluna*** \\
\hline 41 & $\begin{array}{l}\text { A-Camiseta com manchas de sangue } \\
\text { B-Sangue coletado de cadáver }\end{array}$ & A e B-Resina magnética* \\
\hline 42 & $\begin{array}{l}\text { Óculos de sol com eventuais células de } \\
\text { descamação }\end{array}$ & Resina magnética* \\
\hline 43 & $\begin{array}{c}\text { A-Material subungueal coletado do cadáver } \\
1 \\
\text { B-Sangue coletado do cadáver } 1 \\
\text { C-Sangue coletado de cadáver } 2 \\
\text { A-Estofamento de veículo }\end{array}$ & A, B e C-Resina magnética* \\
\hline 44 & $\begin{array}{l}\text { B-Tapete de borracha de veículo com } \\
\text { supostas manchas de sangue }\end{array}$ & A e B-Resina magnética* \\
\hline
\end{tabular}


Tabela 4 - Identificação dos materiais e respectivo método de extração de DNA.

\begin{tabular}{l|ccc} 
Caso & Identificação do material & Método de extração de DNA \\
\hline $\mathbf{4 5}$ & Mancha de sangue coletada de veículo & Resina magnética* \\
$\mathbf{4 6}$ & A-Brinco com manchas de sangue & A e B-Resina magnética* \\
& $\begin{array}{c}\text { B-Bojo de sutiã com manchas de sangue } \\
\text { C-Cueca com manchas de sêmen }\end{array}$ & C- Orgânica com precipitação por álcool \\
$\mathbf{4 7}$ & Mancha de sangue coletada de veículo & Resina magnética* \\
$\mathbf{4 8}$ & $\begin{array}{c}\text { Fragmento de vidro com mancha de sangue } \\
\text { A-Gaze contendo mancha de sangue-sítio 1 }\end{array}$ & Resina magnética* \\
$\mathbf{4 9}$ & $\begin{array}{c}\text { B-Gaze contendo mancha de sangue-sítio 2 } \\
\text { A-Preservativo íntimo }\end{array}$ & A e B-Resina magnética* \\
$\mathbf{5 0}$ & B-Top feminino com manchas de sêmen & A e B-Resina magnética* \\
& A-Bermuda com manchas de sangue & \\
$\mathbf{5 1}$ & B-Sangue da suposta mãe & A, B e C-Resina magnética* \\
$\mathbf{5 2}$ & C-Sangue do suposto pai & Resina magnética* \\
$\mathbf{5 3}$ & Bituca de cigarro com células de & descamação & Resina magnética* \\
\hline & Swab bucal com células epiteliais & TOTAL 80 amostras &
\end{tabular}

FE, Fração Espermatozoide; FNE, Fração Não-Espermatozoide; *Resina magnética DNA IQ $^{\mathrm{TM}}$ System (Promega Corporation, Madison/WI, EUA); **Resina quelante Chelex ${ }^{\circledR} 100$ (Bio-Rad, Hercules/CA, EUA); ****Purificação em coluna Amicon ${ }^{\circledR}$ Ultra -100K - 0,5 (Millipore Corporation, Billerica/MA, EUA).

\subsubsection{Quantificação de DNA}

Após o processo de extração de DNA, as amostras foram quantificadas por PCR em Tempo Real.

Neste estudo utilizamos os reagentes do Quantifiler ${ }^{\circledR}$ Duo DNA Quantification kit (Applied Biosystems, Foster City/CA, EUA), que realiza a quantificação simultânea de DNA humano e masculino através de uma reação multiplex com sondas do sistema TaqMan ${ }^{\circledR}$ MGB, compostas por um controle interno positivo sintético e não humano (IPC) e pelas sondas dos genes-alvo autossômico RPPH1 (Ribonuclease P RNA component H1) e masculino SRY (Sex-determining Region Y). Este sistema é capaz de quantificar a presença de DNA humano e masculino oriundos do processo de extração, de estabelecer a relação entre a quantidade de DNA feminino e masculino nos casos de mistura, assim como diagnosticar a presença de inibidores tais como heme, íons metálicos, produtos do metabolismo bacteriano, ácidos úmicos, dentre outros que impedem a obtenção do perfil genotípico do vestígio biológico. Com a quantificação de DNA masculino e DNA total pode-se estimar a razão entre as misturas e o melhor método, a partir desta informação, para a obtenção do resultado. 
Para cada uma das amostras foi realizada a quantificação por PCR em Tempo Real com o kit acima descrito, com $2 \mu \mathrm{L}$ do volume extraído, em duplicata, utilizando o equipamento 7500 Real Time PCR System (Applied Biosystems, Foster City/CA, EUA), de acordo com os protocolos recomendados pelo fabricante.

\subsubsection{Amplificação de DNA}

\subsubsection{Primers utilizados neste estudo}

As regiões do DNA dos microssatélites D1S1677, D2S441, D4S2364, D10S1248, D14S1434 e D22S1045 foram amplificadas empregando-se a reação em cadeia pela polimerase (PCR). Os primers foram sintetizados pela Applied Biosystems (Foster City/CA, EUA), na escala de 10000pmol, de acordo com as sequências descritas por Coble e Butler (2005), definidos como miniSTRs, sendo que os primers diretos (forward) de cada um dos pares foram marcados com corantes fluorescentes em suas respectivas posições 5'. A tabela abaixo resume as especificações de cada um dos primers.

Tabela 5 - Loci polimórficos, sequências dos primers, fluoróforos, distância do oligonucleotídeo até o início do polimorfismo e concentração dos primers utilizada na reação de PCR.

\begin{tabular}{l|lcc}
\hline $\begin{array}{l}\text { Locus } \\
\text { polimórfico }\end{array}$ & \multicolumn{1}{|c}{$\begin{array}{c}\text { Sequência dos primers (5'-3') } \\
\text { e respectivos fluoróforos }\end{array}$} & $\begin{array}{c}\text { Distância do } \\
\text { oligo. até o } \\
\text { polimorfismo } \\
(\mathbf{b p})\end{array}$ & $\begin{array}{c}\text { Concentração } \\
\text { do primer } \\
(\boldsymbol{\mu M} \mathbf{M})\end{array}$ \\
\hline \multirow{2}{*}{ D1S1677 } & for[NED]-TTCTGTTGGTATAGAGCAGTGTTT & 0 & 1,3 \\
& rev GTGACAGGAAGGACGGAATG* & 0 & 1,3 \\
D2S441 & for[VIC]-CTGTGGCTCATCTATGAAAACTT & 0 & 0,7 \\
& rev GAAGTGGCTGTGGTGTTATGAT* & 0 & 0,7 \\
D4S2364 & for[FAM]-CTAGGAGATCATGTGGGTATGATT & 2 & 1,1 \\
& rev GCAGTGAATAAATGAACGAATGGA* & $-7 * *$ & 1,1 \\
D10S1248 & for[FAM]-TTAATGAATTGAACAAATGAGTGAG & 1 & 1,3 \\
& rev GCAACTCTGGTTGTATTGTCTTCAT* & 0 & 1,3 \\
D14S1434 & for[VIC]-TGTAATAACTCTACGACTGTCTGTCTG & $-11^{* *}$ & 1,3 \\
& rev GAATAGGAGGTGGATGGATGG* & 0 & 1,3 \\
D22S1045 & for[NED]-ATTTTCCCCGATGATAGTAGTCT & 3 & 0,8 \\
& rev GCGAATGTATGATTGGCAATATTTTT* & 6 & 0,8 \\
\hline
\end{tabular}

FONTE: Modificado de Coble e Butler (2005).

for, primer direto; rev, primer reverso; NED, fluoróforo NED ${ }^{\mathrm{TM}}$; VIC, fluoróforo VIC ${ }^{\mathrm{TM}}$; FAM, fluoróforo FAM $^{\mathrm{TM}}$ (fluoróforo da Applied Biosystems Foster City/CA, EUA); * o resíduo de Guanina na posição 5' do primer reverso foi adicionado para promover a adenilação; ** o número negativo indica que a porção final do primer é complementar a uma região da própria sequência repetitiva (correspondendo aos nucleotídeos sublinhados na posição 3' do primer); oligo., oligonucleotídeo; bp; pares de bases (base pair). 


\subsubsection{Validação dos primers}

Para avaliação dos primers adquiridos para a amplificação de cada uma das regiões polimórficas, foram realizadas reações de PCR exclusivas para cada par de iniciadores, utilizando-se amostras de DNA controle na concentração de 1ng por reação. Os controles utilizados e respectivos fabricantes foram os seguintes:

- 9947A (Applied Biosystems, Foster City/CA, EUA) - DNA purificado de linhagem celular de indivíduo do sexo feminino, caucasóide, com 31 anos de idade;

- 9948 (Applied Biosystems, Foster City/CA, EUA) - DNA purificado de linhagem celular de indivíduo do sexo masculino;

- ABI 007 (Applied Biosystems, Foster City/CA, EUA) - DNA genômico de humano do sexo masculino;

- K562 (Promega Corporation, Madison/WI, EUA) - DNA purificado de linhagem celular de leucemia mieloide crônica humana.

Estes controles foram selecionados devido ao fato de existirem publicados os alelos esperados para cada um dos loci deste trabalho. Estes dados podem ser encontrados no Banco de dados de STRs na Internet - STRBase - Short Tandem Repeat DNA Internet Database (STRBASE, 2010). Além disto, estes DNAs controle são comumente utilizados e são adquiridos juntamente com os kits comerciais de análise de microssatélites na área forense.

Volumes correspondentes a uma massa de $1 \mathrm{ng}$ de DNA de cada um dos controles acima discriminados foram submetidos à reação de PCR, no termociclador GeneAmp ${ }^{\circledR} P C R$ System 9700 Thermal Cycler (Applied Biosystems, Foster City/CA, EUA), seguindo protocolos modificados a partir do descrito por Coble e Butler (2005) e os disponíveis no STRBase (STRBASE, 2010). As reações foram padronizadas para um volume final de 12,5 $\mu \mathrm{L}$ e 30 ciclos de amplificação; a Tabela 6 descreve as condições das reações de PCR utilizadas nesta fase. 
Tabela 6 - Componentes, concentrações e programação das reações de PCR utilizadas na etapa de validação dos primers.

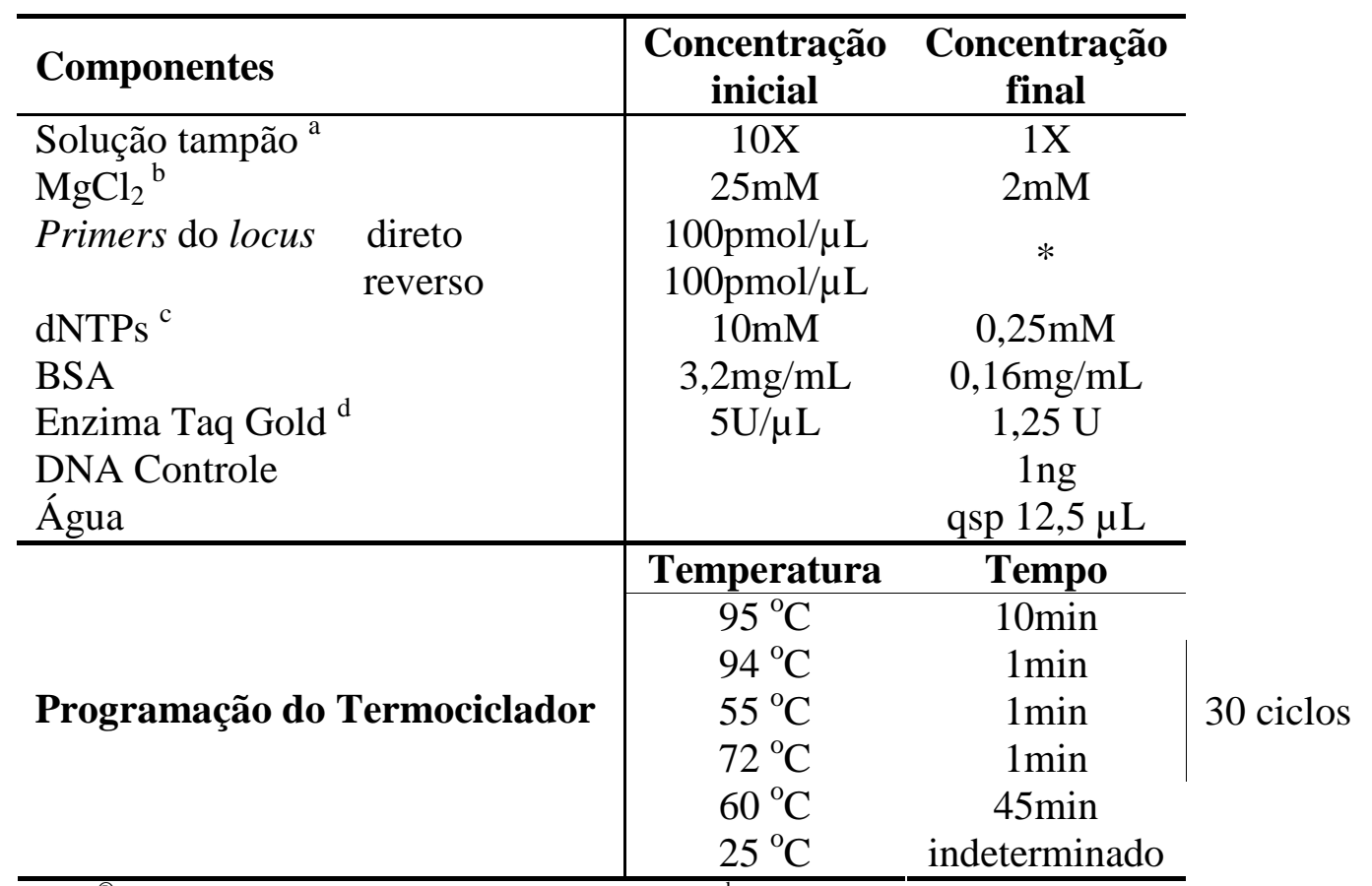

${ }^{\mathrm{a}}$ GeneAmp ${ }^{\Theta}$ PCR Gold buffer (Applied Biosystems); ${ }^{b}$ Cloreto de magnésio (Applied Biosystems); ${ }^{\mathrm{c}} \mathbf{d N T P s}$, desoxinucleotídeos trifosfato GeneAmp ${ }^{\circledR}$ dNTP Mix with dTTP $100 \mathrm{mM}, 25 \mathrm{mM}$ cada (Applied Biosystems); BSA, Albumina Bovina Ultrapura (Applied Biosystems); ${ }^{\mathrm{d}}$ AmpliTaq Gold ${ }^{\mathrm{TM}}$ (250U) (Applied Biosystems); U, unidades de enzima; * concentrações de cada par de primers conforme descrito na Tabela 5; min, minutos; qsp, quantidade suficiente para.

\subsubsection{Validação das reações multiplex $\mathrm{NCO} 1$ e NCO2}

Para a análise dos microssatélites neste estudo, conforme descrito por Coble e Butler (2005), foram realizadas duas reações do tipo multiplex, sendo o triplex NC01 (Non-CODIS 01) correspondente à amplificação simultânea dos loci D10S1248, D14S1434 e D22S1045 e o triplex NC02 (Non-CODIS 02) dos loci D1S1677, D2S441 e D4S2364.

Seguindo-se as mesmas condições apresentadas na Tabela 6, duplicatas de volumes correspondentes a uma massa de $1 \mathrm{ng}$ de DNA de cada um dos DNA controles acima descritos foram submetidos à reação de PCR.

Nas situações em que houve necessidade de otimização das reações de amplificação e dos respectivos resultados obtidos, utilizou-se o QIAGEN $^{\circledR}$ Multiplex PCR Kit (QIAGEN, Hilden, Alemanha) que é composto de uma mistura de enzima, tampão e desoxinucleotídeos trifosfato (HotStarTaq ${ }^{\circledR}$ DNA Polymerase, Multiplex PCR Buffer com $6 \mathrm{mM}$ de $\mathrm{MgCl}_{2}$ e dNTP Mix - QIAGEN, Hilden, Alemanha) e que, segundo o fabricante é apropriado para reações do 
tipo multiplex já que as proporções pré-definidas de seus componentes asseguram a eficiência no anelamento e extensão de todos os primers presentes na reação, com alta especificidade.

\subsubsection{Reações multiplex NCO1 e NCO2}

Após os experimentos iniciais, foram definidas as condições ideais de composição e programações para cada um dos triplex analisados, para que as amostras forenses pudessem ser submetidas à amplificação através destes sistemas.

As Tabelas 7 e 8 apresentam as reações de amplificação que foram submetidas as 80 amostras de casos de análise forense de DNA, para os sistemas NC01 e NC02.

Tabela 7 - Componentes, concentrações e programação das reações de PCR utilizadas na reação multiplex NC01.

\begin{tabular}{|c|c|c|c|}
\hline Componentes & $\begin{array}{c}\text { Concentração } \\
\text { inicial }\end{array}$ & $\begin{array}{c}\text { Concentração } \\
\text { final }\end{array}$ & $\begin{array}{c}\text { Volume } \\
\text { para } 1 \\
\text { amostra }\end{array}$ \\
\hline $\begin{array}{l}\text { QIAGEN }^{\circledR} \text { Multiplex PCR Master Mix } \\
\text { Mix primers NC01 } \\
\text { DNA da amostra } \\
\text { Água }\end{array}$ & $2 X$ & $\begin{array}{c}1 \mathrm{X} \\
* \\
1 \mathrm{ng}\end{array}$ & $\begin{array}{c}6,25 \mu \mathrm{L} \\
1,25 \mu \mathrm{L} \\
\text { até } 5 \mu \mathrm{L} \\
\text { qsp } 12,5 \mu \mathrm{L}\end{array}$ \\
\hline Programação do Termociclador & $\begin{array}{c}\text { Temperatura } \\
95{ }^{\circ} \mathrm{C} \\
94{ }^{\circ} \mathrm{C} \\
57{ }^{\circ} \mathrm{C} \\
72{ }^{\circ} \mathrm{C} \\
60^{\circ} \mathrm{C} \\
4{ }^{\circ} \mathrm{C}\end{array}$ & $\begin{array}{c}\text { Tempo } \\
15 \mathrm{~min} \\
30 \mathrm{seg} \\
1 \mathrm{~min} 30 \mathrm{seg} \\
1 \mathrm{~min} \\
30 \mathrm{~min} \\
\text { indeterminado }\end{array}$ & 30 ciclos \\
\hline
\end{tabular}

${ }^{\mathrm{Q}} \overline{\text { IAGEN }{ }^{\circledR} \text { Multiplex PCR Master Mix (QIAGEN); *Concentrações de cada par de primers referentes aos loci }}$ polimórficos D10S1248, D14S1434 e D22S1045, de acordo com o exposto na Tabela 5; min, minutos; seg, segundos; qsp, quantidade suficiente para.

Foram realizados testes da utilização do QIAGEN $^{\circledR}$ Multiplex PCR Kit (QIAGEN, Hilden, Alemanha) também para o multiplex NC02 (dados não ilustrados), mas na ausência de alterações significativas nos resultados obtidos optou-se pelo emprego da composição de tampão de reação proposta inicialmente, por seu menor custo, conforme demonstrado na Tabela 8 , a seguir. 
Tabela 8 - Componentes, concentrações e programação das reações de PCR utilizadas na reação multiplex NC02.

\begin{tabular}{|c|c|c|c|}
\hline Componentes & $\begin{array}{l}\text { Concentração } \\
\text { inicial }\end{array}$ & $\begin{array}{c}\text { Concentração } \\
\text { final }\end{array}$ & $\begin{array}{c}\text { Volume } \\
\text { para } 1 \\
\text { amostra }\end{array}$ \\
\hline \multirow{8}{*}{$\begin{array}{l}\text { Solução tampão }{ }^{\text {a }} \\
\mathrm{MgCl}_{2}{ }^{{ }^{2}} \\
\text { Mix primers } \mathrm{NCO} 2 \\
\text { dNTPs }^{\mathrm{c}} \\
\text { BSA } \\
\text { Enzima Taq Gold } \\
\text { DNA da amostra } \\
\text { Água }\end{array}$} & $10 X$ & $1 \mathrm{X}$ & $1,25 \mu \mathrm{L}$ \\
\hline & $25 \mathrm{mM}$ & $2 \mathrm{mM}$ & $1 \mu \mathrm{L}$ \\
\hline & & $*$ & $1,25 \mu \mathrm{L}$ \\
\hline & $10 \mathrm{mM}$ & $0,25 \mathrm{mM}$ & $0,3125 \mu \mathrm{L}$ \\
\hline & $3,2 \mathrm{mg} / \mathrm{mL}$ & $0,16 \mathrm{mg} / \mathrm{mL}$ & $0,625 \mu \mathrm{L}$ \\
\hline & $5 \mathrm{U} / \mu \mathrm{L}$ & $1,25 \mathrm{U}$ & $0,25 \mu \mathrm{L}$ \\
\hline & & 1ng & até $5 \mu \mathrm{L}$ \\
\hline & & & qsp $12,5 \mu \mathrm{L}$ \\
\hline \multirow{7}{*}{ Programação do Termociclador } & Temperatura & Tempo & \multirow{7}{*}{30 ciclos } \\
\hline & $95^{\circ} \mathrm{C}$ & $10 \mathrm{~min}$ & \\
\hline & $94{ }^{\circ} \mathrm{C}$ & $1 \mathrm{~min}$ & \\
\hline & $55^{\circ} \mathrm{C}$ & $1 \mathrm{~min}$ & \\
\hline & $72{ }^{\circ} \mathrm{C}$ & $1 \mathrm{~min}$ & \\
\hline & $60{ }^{\circ} \mathrm{C}$ & $45 \mathrm{~min}$ & \\
\hline & $25{ }^{\circ} \mathrm{C}$ & indeterminado & \\
\hline
\end{tabular}

${ }^{\mathrm{a}}$ GeneAmp ${ }^{\Theta}$ PCR Gold buffer (Applied Biosystems); ${ }^{\mathrm{b}}$ Cloreto de magnésio (Applied Biosystems); ${ }^{\mathrm{C}} \mathbf{d N T P s}$, desoxinucleotídeos trifosfato GeneAmp ${ }^{\circledR}$ dNTP Mix with dTTP 100mM, 25mM cada (Applied Biosystems); *Concentrações de cada par de primers referentes aos loci polimórficos D1S1677, D2S441 e D4S2364, de acordo com o exposto na Tabela 5; BSA, Albumina Bovina Ultrapura (Applied Biosystems); ${ }^{\mathrm{d} A m p l i T a q}$ Gold $\mathrm{TM}$ (250U) (Applied Biosystems); U, unidades de enzima; min, minutos; qsp, quantidade suficiente para.

\subsubsection{Detecção dos produtos amplificados}

Após as reações de amplificação, as amostras foram submetidas à eletroforese capilar no equipamento ABI 3130 Genetic Analyzer (Applied Biosystems, Foster City/CA-EUA) com capacidade para 4 capilares, que detecta em tempo real a fluorescência emitida pelos fluoróforos utilizados para a marcação dos primers.

Alíquota de $1 \mu \mathrm{L}$ de cada DNA amplificado foi adicionado a uma mistura contendo 8,7 $\mu \mathrm{L}$ do agente desnaturante formamida (HI-DI ${ }^{\mathrm{TM}}$ formamide, Applied Biosystems) e 0,3 $\mu \mathrm{L}$ do padrão interno de peso molecular GS500 LIZ size standard (Applied Biosystems). Para o sistema de eletroforese foram utilizados o tampão $1 X$ Genetic Analyzer Buffer w/EDTA (Applied Biosystems), o polímero POP-4 polymer (Applied Biosystems) e o capilar de $36 \mathrm{~cm}$ $36 \mathrm{~cm}$ capillary array (Applied Biosystems), de acordo com o preconizado pelos protocolos do fabricante. A injeção das amostras no capilar ocorreu durante 5 segundos a 15000 Volts e a separação eletroforética a $60{ }^{\circ} \mathrm{C}$, por 25 minutos, sendo neste período as amostras excitadas na 
janela de detecção por um laser de argônio, com energia no comprimento de onda de 488nm. Para a detecção simultânea dos 4 fluoróforos utilizados neste estudo, FAM (para os loci D4S2364 e D10S1248), VIC (para os loci D2S441 e D14S1434), NED (para os loci D1S1677 e D22S1045) e LIZ (padrão de peso molecular) o equipamento foi previamente calibrado, no filtro G5, com os padrões de matriz Matrix Standard DS-33 (Applied Biosystems).

Durante o processo eletroforético, a fluorescência dos fluoróforos utilizados na marcação dos primers foi captada pela câmera CCD do equipamento e pelo Data Collection Software v3.1 (Applied Biosystems), que converte o sinal luminoso em picos do eletroferograma. O processo de total eletroforese durou aproximadamente 40 minutos para cada 4 amostras e o equipamento possui autonomia para análise de até 96 amostras sem a intervenção do usuário (cerca de 16 horas).

\subsubsection{Análise dos resultados}

A genotipagem e atribuição dos alelos foi realizada após a eletroforese capilar com o auxílio do programa GeneMapper ID v3.2 (Applied Biosystems). Através da comparação entre a migração da amostra e do padrão de peso molecular juntamente com ela aplicado, o software determinou o tamanho dos alelos, em pares de bases. Para alimentação dos parâmetros de análise do programa, pelo fato de não dispormos de uma escada alélica para os sistemas amplificados, realizou-se o download dos arquivos com os painéis de alelos e faixas de tamanhos esperados para os alelos (bins - em pares de bases) disponíveis na Internet no STRBase (STRBASE, 2010). Os ajustes necessários no tamanho esperado em pares de bases para cada um dos alelos, devido a diferenças de equipamentos, reagentes e condições da eletroforese capilar foram realizados com bases nos alelos conhecidos esperados para cada um dos DNA controle utilizados na fase de validação dos multiplex NC01 e NC02.

Foi avaliada a obtenção de perfil alélico ou ausência de amplificação em cada um dos loci polimórficos, para cada uma das 80 amostras e estabelecidas comparações, quando cabíveis, com a qualidade dos respectivos materiais biológicos e a quantificação de DNA relacionada.

Os alelos obtidos para os seis polimorfismos foram tabulados e casos especiais em que havia materiais comparáveis (quando possuíamos amostras-referência disponíveis e que também foram amplificadas) ou com informações prévias de mutações presentes nos sistemas rotineiramente utilizados no laboratório foram analisados com maior detalhe. 
4 RESULTADOS 


\subsection{Validação dos primers}

O fato de não dispormos de uma escada alélica para os sitemas amplificados determinou que os ajustes das faixas de tamanhos esperados para os alelos (bins - em pares de bases), devido a diferenças entre equipamentos, reagentes e condições da eletroforese capilar, em relação às disponíveis na Internet no STRBase (STRBASE, 2010), fossem realizados com bases nos alelos conhecidos para cada um dos DNA controle utilizados na fase de validação dos primers e dos multiplex NC01 e NC02. Os alelos para cada locus e os respectivos tamanhos ajustados no software GeneMapper ID v 3.2, encontram-se na Tabela 9. Para todos os loci, o tamanho dos bins teve uma variação de mais ou menos 0,5 pares de bases ao redor do valor médio obtido para os alelos dos DNA controles.

Tabela 9 - Loci polimórficos, alelos mais comuns e tamanhos esperados em pares de bases com base nos alelos dos controles de DNA utilizados, após ajustes no software de análise.

\begin{tabular}{|c|c|c|c|c|c|c|c|c|c|c|c|}
\hline \multicolumn{2}{|c|}{$\begin{array}{c}\text { Locus } \\
\text { D1S1677 }\end{array}$} & \multicolumn{2}{|c|}{$\begin{array}{c}\text { Locus } \\
\text { D2S441 }\end{array}$} & \multicolumn{2}{|c|}{$\begin{array}{c}\text { Locus } \\
\text { D4S2364 }\end{array}$} & \multicolumn{2}{|c|}{$\begin{array}{c}\text { Locus } \\
\text { D10S1248 }\end{array}$} & \multicolumn{2}{|c|}{$\begin{array}{c}\text { Locus } \\
\text { D14S1434 }\end{array}$} & \multicolumn{2}{|c|}{$\begin{array}{c}\text { Locus } \\
\text { D22S1045 }\end{array}$} \\
\hline alelo & bp & alelo & bp & alelo & bp & alelo & bp & alelo & bp & alelo & $\mathrm{bp}$ \\
\hline 9 & 75,70 & 9 & 76,24 & 6 & 62,50 & 8 & 78,10 & 7 & 61,46 & 6 & 68,30 \\
\hline 10 & 79,87 & 10 & 80,33 & 7 & 66,50 & 9 & 82,10 & 8 & 65,46 & 7 & 71,30 \\
\hline 11 & 83,80 & 11 & 84,43 & 8 & 70,50 & 10 & 86,24 & 9 & 69,00 & 8 & 74,30 \\
\hline 12 & 88,11 & 11.3 & 87,51 & 9 & 74,50 & 11 & 90,38 & 10 & 72,60 & 9 & 77,40 \\
\hline 13 & 92,47 & 12 & 88,53 & 10 & 78,50 & 12 & 94,52 & 11 & 76,80 & 10 & 80,50 \\
\hline 14 & 96,53 & 12.3 & 91,61 & 11 & 82,50 & 13 & 98,71 & 12 & 80,70 & 11 & 83,60 \\
\hline 15 & 100,41 & 13 & 92,63 & 12 & 86,50 & 14 & 102,58 & 13 & 84,60 & 12 & 86,70 \\
\hline 16 & 104,51 & 13.3 & 95,71 & 13 & 90,50 & 15 & 106,51 & 14 & 88,98 & 13 & 89,80 \\
\hline 17 & 108,49 & 14 & 96,73 & & & 16 & 110,55 & 15 & 93,16 & 14 & 92,90 \\
\hline 18 & 112,20 & 14.3 & 99,81 & & & 17 & 114,49 & 16 & 97,44 & 15 & 96,00 \\
\hline 19 & 116,41 & 15 & 100,83 & & & 18 & 118,48 & 17 & 101,44 & 16 & 99,10 \\
\hline \multirow[t]{5}{*}{20} & 120,50 & 16 & 104,93 & & & 19 & 122,45 & 18 & 105,10 & 17 & 102,20 \\
\hline & & 17 & 109,03 & & & 20 & 126,51 & 19 & 109,00 & 18 & 105,30 \\
\hline & & & & & & 21 & 130,51 & 20 & 112,90 & 19 & 108,40 \\
\hline & & & & & & 22 & 134,55 & & & 20 & 111,50 \\
\hline & & & & & & 23 & 138,55 & & & 21 & 114,50 \\
\hline
\end{tabular}

bp, tamanho do alelo em pares de bases.

Os resultados obtidos após a etapa de amplificação das amostras de DNA controle, em reações de PCR individuais para cada locus encontram-se dispostos nas Figuras 9, 10, 11, 12, 13 e 14. As reações foram realizadas em duplicata, porém, quando houve coincidência no resultado obtido somente uma imagem foi reproduzida. Os controles negativos, nos quais não 
se adicionou DNA molde no interior do tubo de reação, não apresentaram amplificação para nenhum dos loci, conforme esperado.

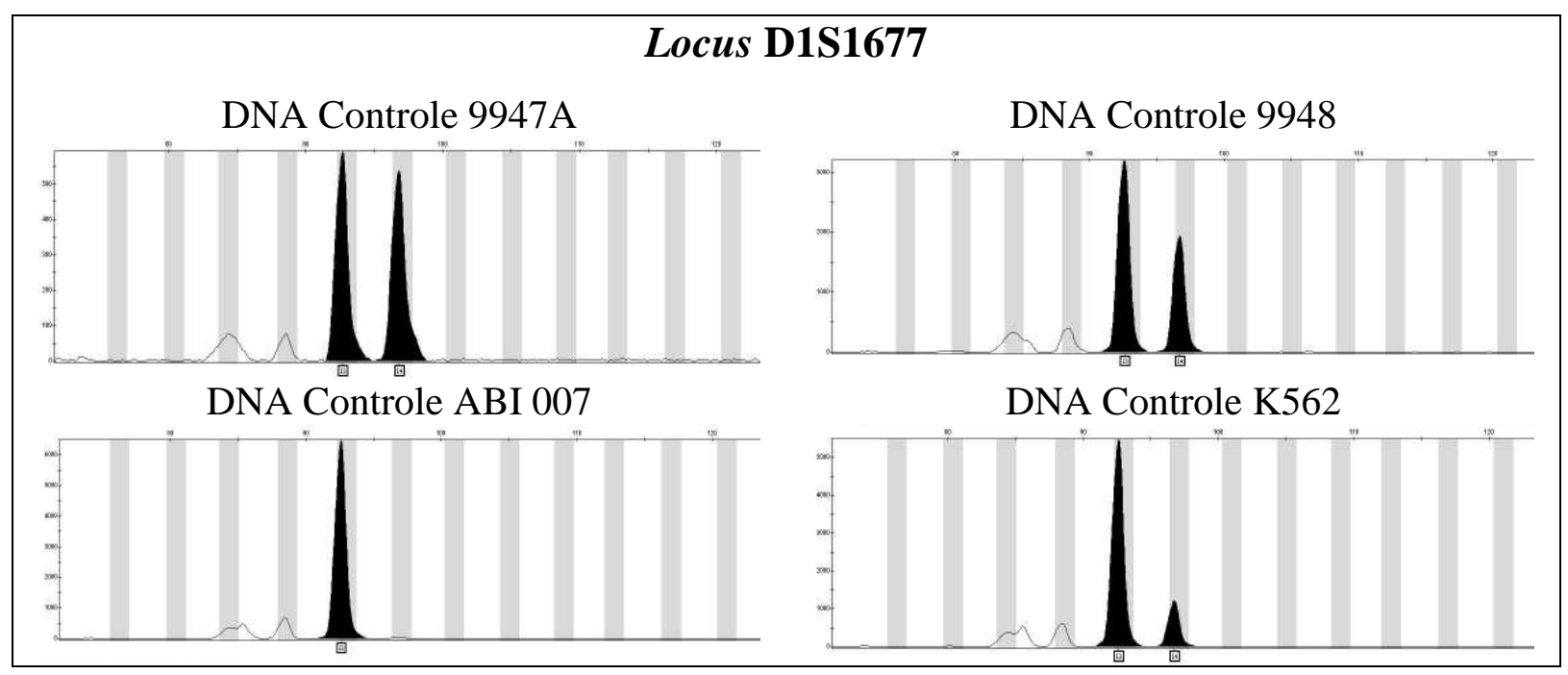

Figura 9 - Eletroferogramas obtidos após a amplificação dos DNA controles 9947A, 9948, ABI 007 e K562 com o par de primers para o locus D1S1677, com o fluoróforo NED. Eixo x, tamanho em pares de bases; eixo y, unidade relativa de fluorescência (relative fluorescence unit - RFU).

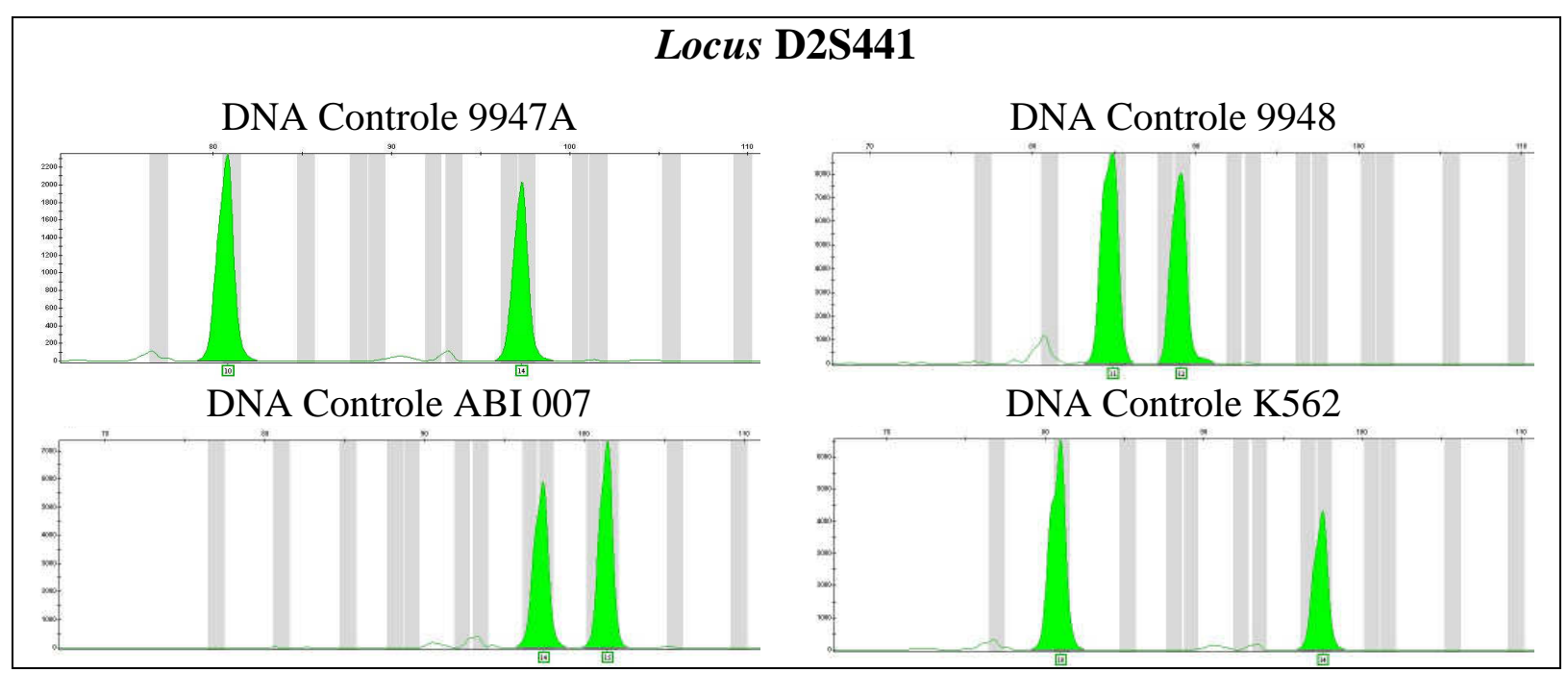

Figura 10 - Eletroferogramas obtidos após a amplificação dos DNA controles 9947A, 9948, ABI 007 e K562 com o par de primers para o locus D2S441, com o fluoróforo VIC. Eixo x, tamanho em pares de bases; eixo $\mathrm{y}$, unidade relativa de fluorescência (relative fluorescence unit - RFU). 


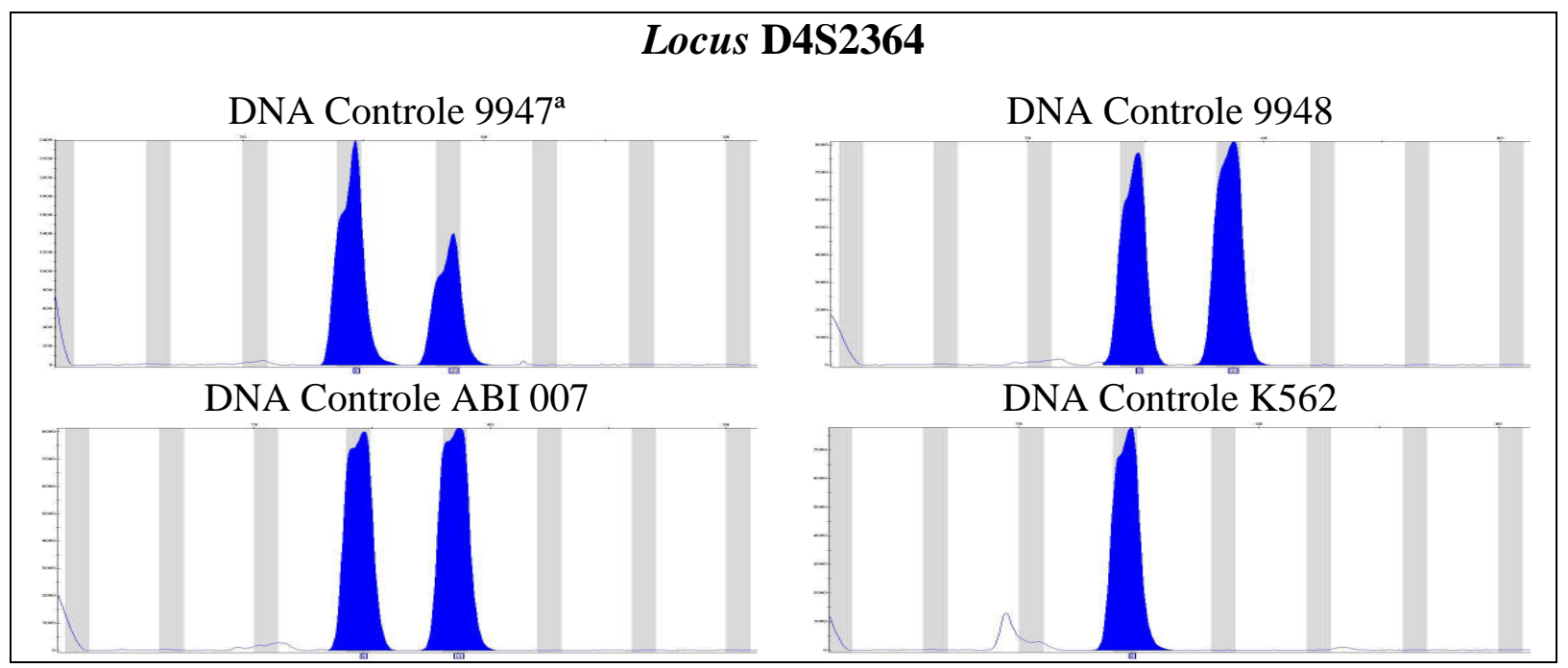

Figura 11 - Eletroferogramas obtidos após a amplificação dos DNA controles 9947A, 9948, ABI 007 e K562 com o par de primers para o locus D4S2364, com o fluoróforo FAM. Eixo x, tamanho em pares de bases; eixo $\mathrm{y}$, unidade relativa de fluorescência (relative fluorescence unit - RFU).

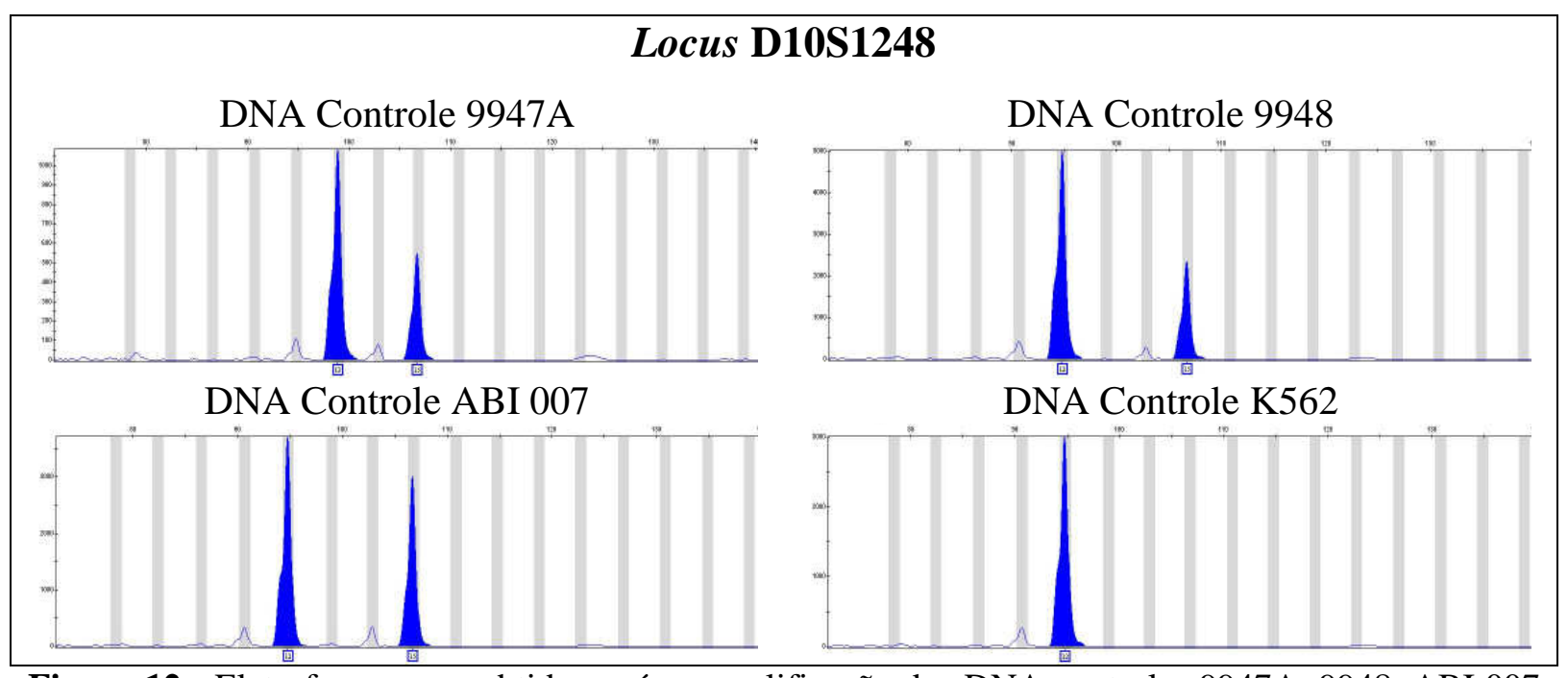

Figura 12 - Eletroferogramas obtidos após a amplificação dos DNA controles 9947A, 9948, ABI 007 e K562 com o par de primers para o locus D10S1248, com o fluoróforo FAM. Eixo X, tamanho em pares de bases; eixo $\mathrm{y}$, unidade relativa de fluorescência (relative fluorescence unit - RFU). 


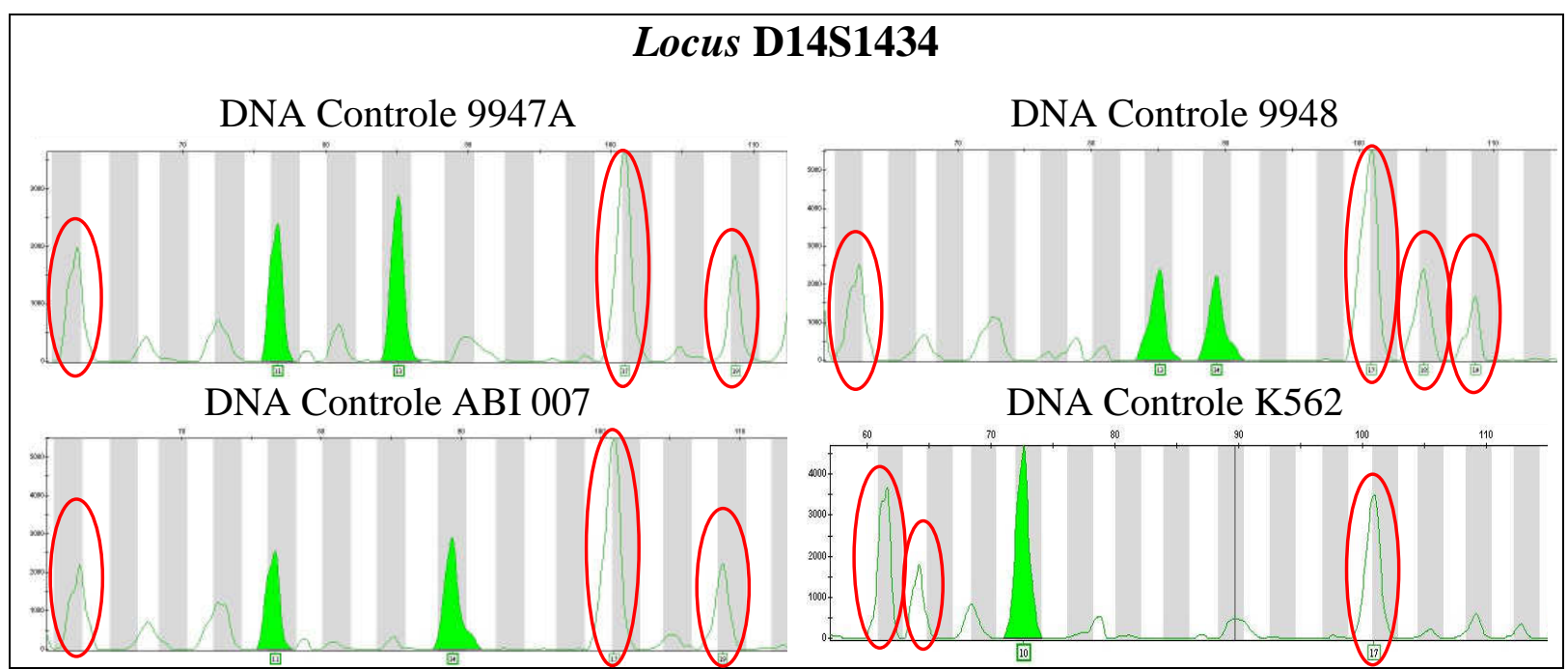

Figura 13 - Eletroferogramas obtidos após a amplificação dos DNA controles 9947A, 9948, ABI 007 e K562 com o par de primers para o locus D14S1434, com o fluoróforo VIC. Eixo x, tamanho em pares de bases; eixo $\mathrm{y}$, unidade relativa de fluorescência (relative fluorescence unit - RFU). Destacados em vermelho estão os picos inespecíficos/artefatos obtidos durante a validação deste locus.

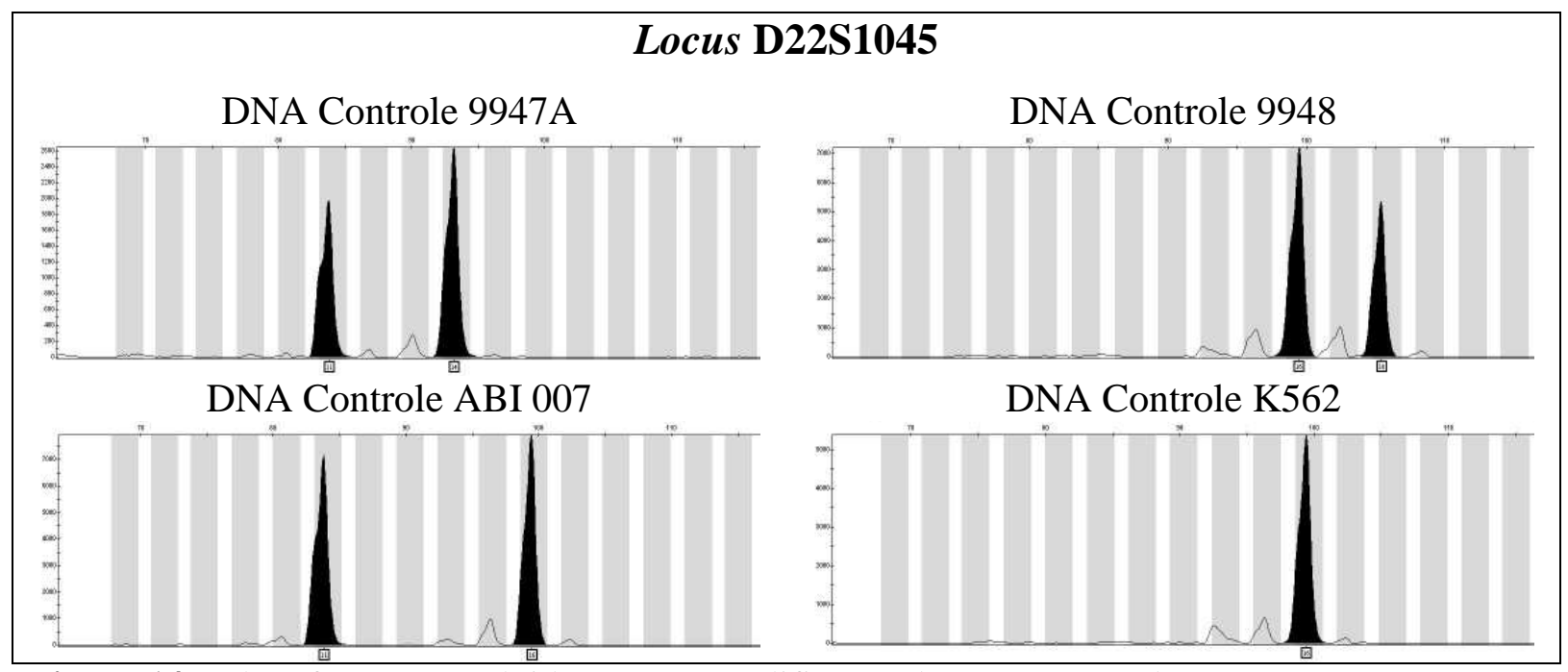

Figura 14 - Eletroferogramas obtidos após a amplificação dos DNA controles 9947A, 9948, ABI 007 e K562 com o par de primers para o locus D22S1045, com o fluoróforo NED. Eixo x, tamanho em pares de bases; eixo y, unidade relativa de fluorescência (relative fluorescence unit - RFU).

\subsection{Validação das reações multiplex NC01 e NC02}

As amostras de DNA controle foram amplificadas nas reações multiplex NC01 e NC02, de acordo com as condições já descritas e os resultados obtidos encontram-se nas figuras 15,16 e 17. 


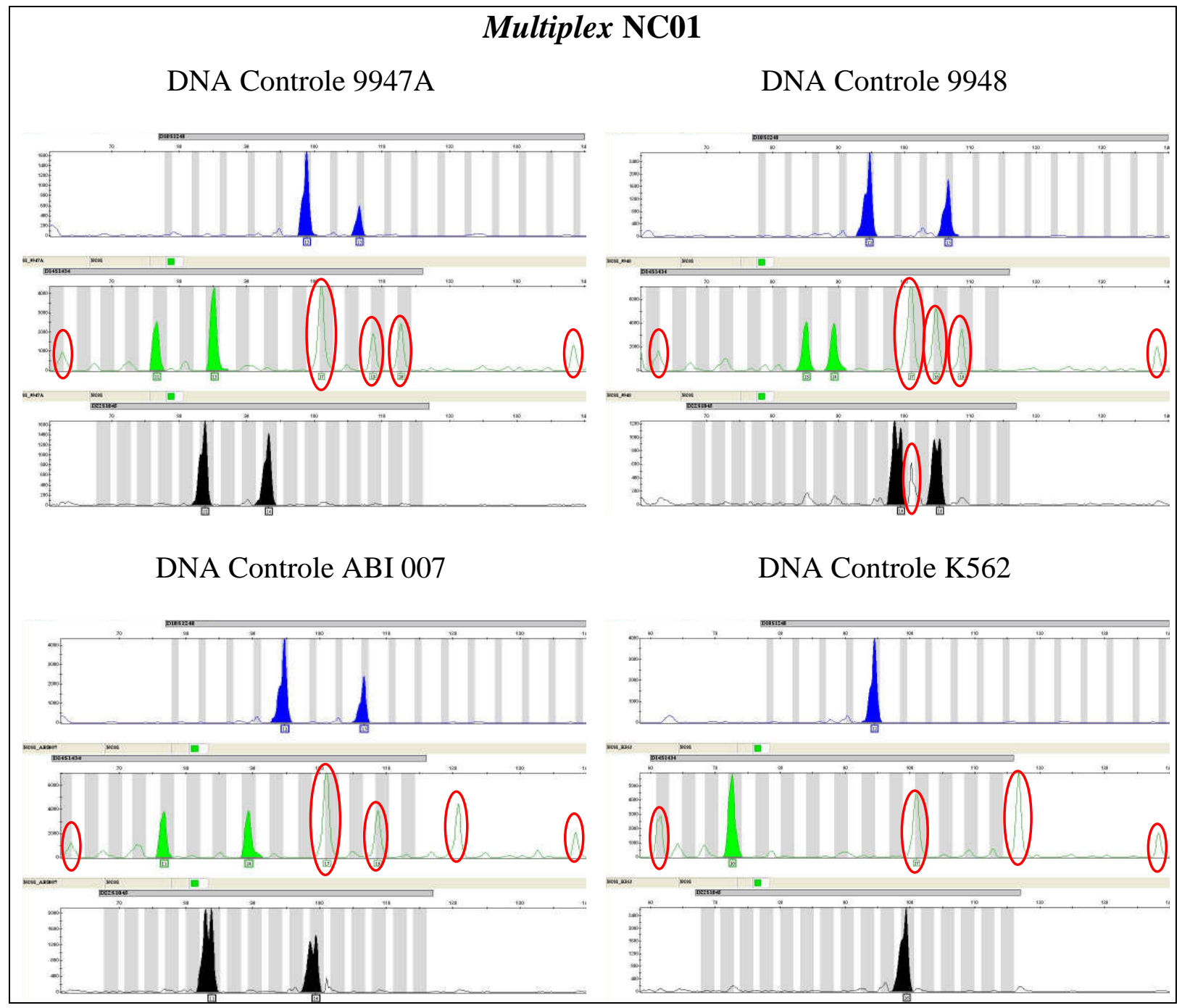

Figura 15 - Eletroferogramas obtidos após a amplificação dos DNA controles 9947A, 9948, ABI 007 e K562 com os três pares de primers simultaneamente para o multiplex NC01 (loci D10S1248, D14S1434 e D22S1045), marcados, respectivamente, com os fluoróforos FAM, VIC e NED. Eixo x, tamanho em pares de bases; eixo y, unidade relativa de fluorescência (relative fluorescence unit - RFU). Destacados em vermelho estão os picos inespecíficos/artefatos obtidos durante a validação deste multiplex.

$\mathrm{Na}$ expectativa da redução ou eliminação dos picos inespecíficos/artefatos obtidos durante a validação da reação multiplex NC01, optamos por utilizar o $Q I A G E N^{\circledR}$ Multiplex PCR Kit (QIAGEN, Hilden, Alemanha). Os resultados obtidos após o uso destes reagentes de otimização no triplex NC01, estão expostos na Figura 16.

A Figura 16 mostra a melhoria da qualidade dos resultados, principalmente para o locus D14S434, com o uso do QIAGEN ${ }^{\circledR}$ Multiplex PCR Kit (QIAGEN, Hilden, Alemanha). Pode-se observar a redução na intensidade da fluorescência dos picos inespecíficos/artefatos, que apesar de não terem sido completamente eliminados apresentam-se em condições de risco muito menor de serem confundidos com os reais alelos das amostras. 


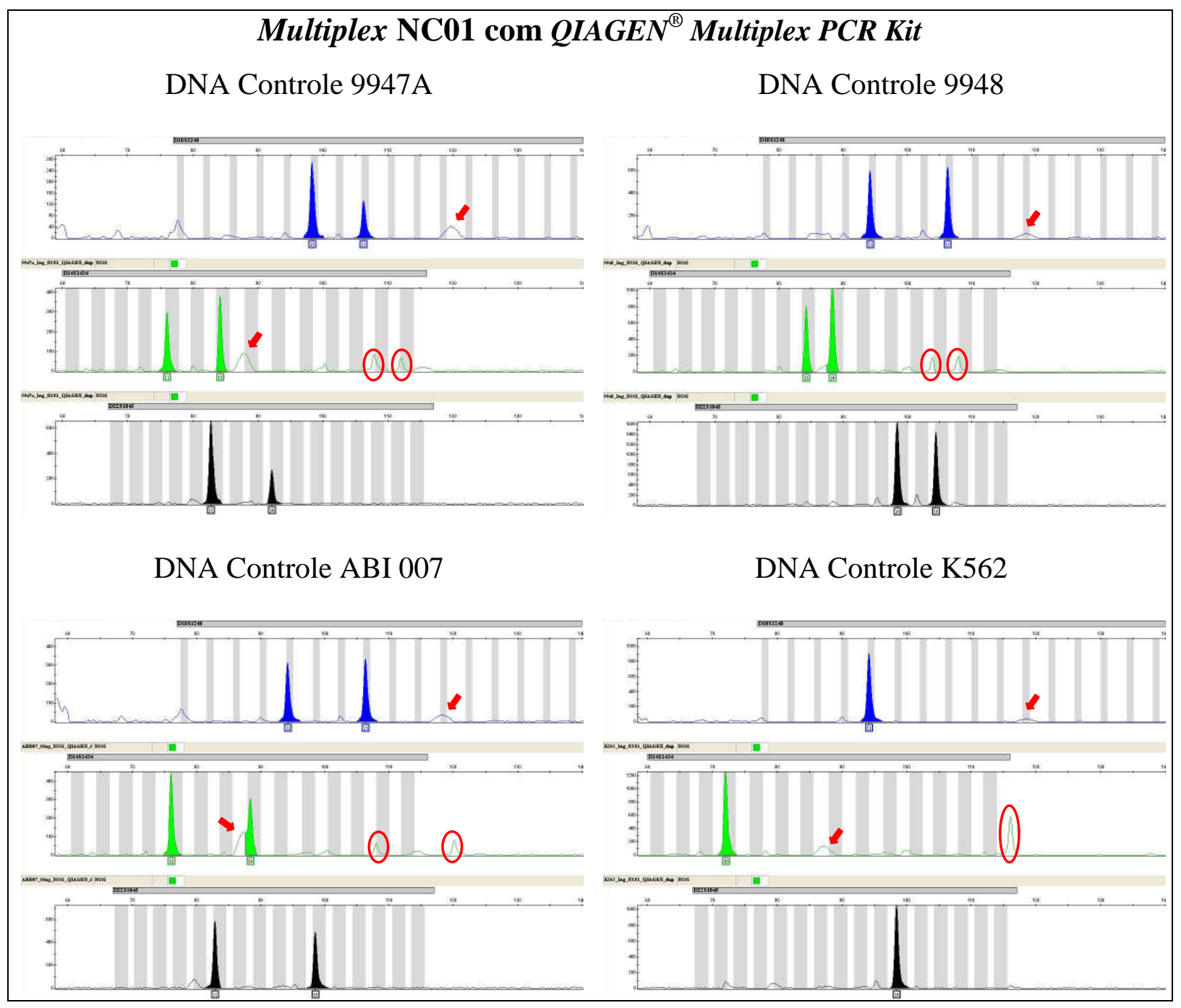

Figura 16 - Eletroferogramas obtidos após a amplificação dos DNA controles 9947A, 9948, ABI 007 e K562 com os três pares de primers simultaneamente para o multiplex NC01 (loci D10S1248, D14S1434 e D22S1045), marcados, respectivamente, com os fluoróforos FAM, VIC e NED e utilizando-se o QIAGEN $^{\circledR}$ Multiplex PCR Kit (QIAGEN). Eixo x, tamanho em pares de bases; eixo $\mathrm{y}$, unidade relativa de fluorescência (relative fluorescence unit - RFU). Circulados em vermelho estão os picos inespecíficos/artefatos obtidos durante a validação deste multiplex e as setas indicam a presença de dye blobs (artefatos do fluoróforo). 


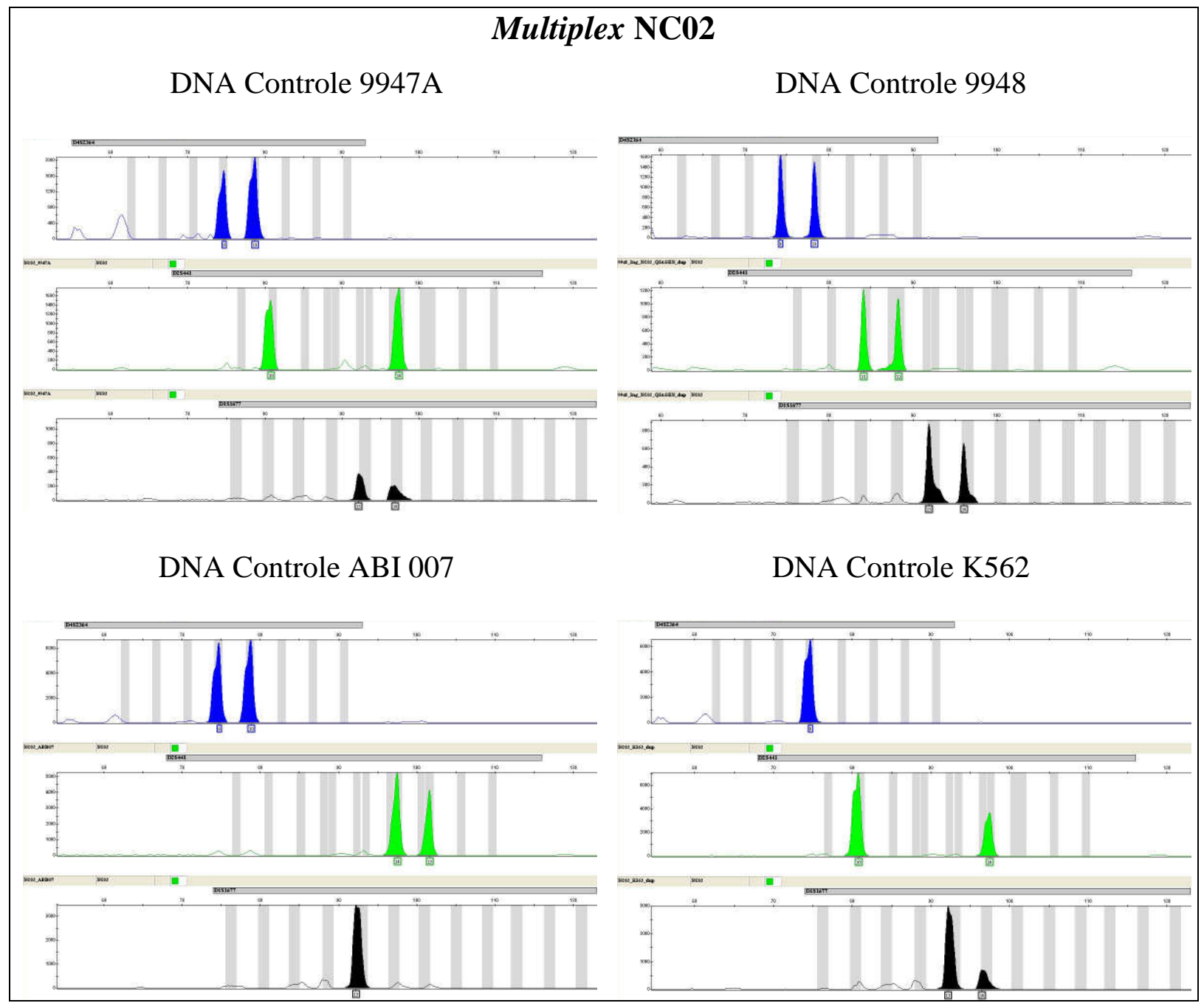

Figura 17 - Eletroferogramas obtidos após a amplificação dos DNA controles 9947A, 9948, ABI 007 e K562 com os três pares de primers simultaneamente para o multiplex NC02 (loci D1S1677, D2S441 e D4S2364), marcados, respectivamente, com os fluoróforos NED, VIC e FAM. Eixo x, tamanho em pares de bases; eixo y, unidade relativa de fluorescência (relative fluorescence unit - RFU).

A Tabela 10 demonstra os alelos esperados (STRBASE, 2010) e os alelos obtidos para os DNA controles na fase de validação dos primers e das reações multiplex NC01 e NC02. 
Tabela 10 - Loci polimórficos, controles de DNA e respectivos alelos esperados e obtidos durante as padronizações das reações individuais dos primers e no formato multiplex.

\begin{tabular}{l|cccc|cccc}
\hline & \multicolumn{3}{|c|}{ Alelos esperados } & \multicolumn{4}{c}{ Alelos obtidos } \\
Locus & $9947 \mathrm{~A}$ & 9948 & ABI007 & K562 & $9947 \mathrm{~A}$ & 9948 & ABI007 & K562 \\
\hline D1S1677 & $13 / 14$ & $13 / 14$ & $13 / 13$ & $13 / 14$ & $13 / 14$ & $13 / 14$ & $13 / 13$ & $13 / 14$ \\
D2S441 & $10 / 14$ & $11 / 12$ & $14 / 15$ & $10 / 14$ & $10 / 14$ & $11 / 12$ & $14 / 15$ & $10 / 14$ \\
D4S2364 & $9 / 10$ & $9 / 10$ & $9 / 10$ & $9 / 9$ & $9 / 10$ & $9 / 10$ & $9 / 10$ & $9 / 9$ \\
D10S1248 & $13 / 15$ & $12 / 15$ & $12 / 15$ & $12 / 12$ & $13 / 15$ & $12 / 15$ & $12 / 15$ & $12 / 12$ \\
D14S1434 & $11 / 13$ & $13 / 14$ & $11 / 14$ & $10 / 10$ & $11 / 13 *$ & $13 / 14 *$ & $11 / 14^{*}$ & $10 / 10^{*}$ \\
D22S1045 & $11 / 14$ & $16 / 18$ & $11 / 16$ & $16 / 16$ & $11 / 14$ & $16 / 18$ & $11 / 16$ & $16 / 16$ \\
\hline FONTE: Modificado de Coble e Butler (2005). \\
* alelos principais obtidos após redução dos picos inespecíficos e artefatos, com o uso do QIAGEN ${ }^{\circledR}$ Multiplex \\
PCR Kit (QIAGEN, Hilden, Alemanha).
\end{tabular}

\subsection{Quantificação de DNA}

Após o processo de extração, as amostras forenses foram quantificadas por PCR em tempo real e os resultados obtidos para DNA humano total e DNA masculino para cada grupo experimental encontram-se dispostos nas Tabelas 11, 12 e 13.

Tabela 11 - Quantificação de DNA das amostras referentes aos casos de Identificação de Cadáveres.

\begin{tabular}{l|ccc}
\hline Caso & Identificação do material & $\begin{array}{c}\text { DNA humano } \\
(\mathbf{n g} / \boldsymbol{\mu L})\end{array}$ & $\begin{array}{c}\text { DNA masculino } \\
(\mathbf{n g} / \boldsymbol{\mu L})\end{array}$ \\
\hline $\mathbf{0 1}$ & A-Sangue de cadáver - IQ & 1,501 & 2,099 \\
$\mathbf{0 2}$ & B-Sangue de cadáver - Chelex & 0,876 & 1,558 \\
$\mathbf{0 3}$ & Osso esterno & 0,019 & 0,051 \\
$\mathbf{0 4}$ & Osso fêmur & 0,693 & 1,875 \\
$\mathbf{0 5}$ & Osso fêmur & 0,0006 & 0,014 \\
$\mathbf{0 6}$ & Osso fêmur & 0,008 & 0,029 \\
$\mathbf{0 7}$ & Ossada de recém-nascido & 0 & 0 \\
$\mathbf{0 8}$ & Osso fêmur & 2,689 & 0 \\
$\mathbf{0 9}$ & Sangue de cadáver & 3,474 & 2,610 \\
$\mathbf{1 0}$ & Dentes & 0,008 & 0 \\
$\mathbf{1 1}$ & Osso fêmur & 0,080 & 0,595 \\
$\mathbf{1 2}$ & Osso fêmur & 0,636 & 1,869 \\
$\mathbf{1 3}$ & Osso fêmur & 0,412 & 2,619 \\
$\mathbf{1 4}$ & Osso fêmur & 0,003 & 0,023 \\
$\mathbf{1 5}$ & Osso úmero & 0 & 0 \\
$\mathbf{1 6}$ & Músculo cardíaco de feto & 23,264 & 2,449 \\
$\mathbf{1 7}$ & Músculo da perna de cadáver & 283,086 & 145,617 \\
$\mathbf{1 8}$ & Osso fêmur & 0,013 & 0 \\
$\mathbf{1 9}$ & Osso fêmur & 0,015 & 0,117 \\
\hline
\end{tabular}

IQ, extração realizada com o kit DNA IQ ${ }^{\mathrm{TM}}$ System (Promega Corporation, Madison/WI, EUA); Chelex, extração realizada com a resina quelante Chelex ${ }^{\circledR} 100$ (Bio-Rad, Hercules/CA, EUA). 
Tabela 12 - Quantificação de DNA das amostras referentes aos casos de Crimes Sexuais.

\begin{tabular}{|c|c|c|c|}
\hline Caso & Identificação do material & $\begin{array}{l}\text { DNA humano } \\
(\mathbf{n g} / \mu \mathrm{L})\end{array}$ & $\begin{array}{c}\text { DNA masculino } \\
(\mathrm{ng} / \mu \mathrm{L})\end{array}$ \\
\hline \multirow{2}{*}{20} & A-Swab vaginal-FE & 0,043 & 0,092 \\
\hline & $\mathrm{B}-S w a b$ vaginal-FNE & 95,824 & 0,125 \\
\hline 21 & $\begin{array}{l}\text { Fragmento de lençol com supostas manchas } \\
\text { de sêmen }\end{array}$ & 0 & 0 \\
\hline \multirow{3}{*}{22} & A-Papel de filtro com secreção vaginal-FE & 0,073 & 0,021 \\
\hline & B-Papel de filtro com secreção vaginal-FNE & 0,145 & 0,002 \\
\hline & A-Swab vaginal & 2,591 & 0,002 \\
\hline \multirow[t]{2}{*}{23} & $\mathrm{~B}-S w a b$ vaginal-FE & 0,017 & 0 \\
\hline & $\mathrm{C}-\mathrm{S} w a b$ vaginal-FNE & 5,097 & 0,043 \\
\hline \multirow{2}{*}{24} & A-Osso fêmur de feto & 2760,255 & 0,014 \\
\hline & B-Sangue coletado do suposto pai & 1,534 & 2,736 \\
\hline 25 & Conteúdo uterino em caso de aborto & 276,793 & 20,327 \\
\hline 26 & Swab vaginal & 3,873 & 0,023 \\
\hline 27 & Calcinha com manchas de sêmen & 0,0001 & 0 \\
\hline 28 & $\begin{array}{c}\text { Espátula de madeira contendo secreção } \\
\text { vaginal }\end{array}$ & 0,001 & 0 \\
\hline \multirow{2}{*}{29} & A-Swab anal-FE & 8,485 & 0,673 \\
\hline & B-Swab anal-FNE & 6,611 & 0,207 \\
\hline \multirow{2}{*}{30} & A-Swab anal-FE & 3,300 & 0,982 \\
\hline & B-Swab anal-FNE & 2,135 & 0,205 \\
\hline \multirow{2}{*}{31} & A-Urina & 0,659 & 0 \\
\hline & B-Sondas uretrais & 0,084 & 0 \\
\hline \multirow{2}{*}{32} & A-Cueca 1 & 0,024 & 0,051 \\
\hline & B-Cueca 2 & 0,843 & 1,130 \\
\hline \multirow{2}{*}{33} & A-Sangue coletado de suspeito de estupro & 1,182 & 1,976 \\
\hline & B-Sangue coletado de suspeito de estupro & 0,440 & 1,057 \\
\hline \multirow{3}{*}{34} & A-Sangue coletado da mãe-vítima & 0,439 & 0 \\
\hline & B-Sangue da criança & 0,689 & 1,709 \\
\hline & C-Sangue do suposto pai & 2,427 & 4,485 \\
\hline \multirow{3}{*}{35} & A-Sangue coletado da mãe-vítima & 0,681 & 0 \\
\hline & B-Sangue da criança & 0,393 & 0 \\
\hline & C-Sangue do suposto pai & 1,215 & 2,373 \\
\hline
\end{tabular}

FE, Fração Espermatozoide; FNE, Fração Não-Espermatozoide. 
Tabela 13 - Quantificação de DNA das amostras referentes aos casos de análise de vestígios biológicos oriundos de locais de crimes.

\begin{tabular}{|c|c|c|c|}
\hline Caso & Identificação do material & $\begin{array}{l}\text { DNA humano } \\
(\mathrm{ng} / \mu \mathrm{L})\end{array}$ & $\begin{array}{c}\text { DNA masculino } \\
(\mathrm{ng} / \mu \mathrm{L})\end{array}$ \\
\hline 36 & $\begin{array}{l}\text { Fragmento de camiseta com manchas de } \\
\text { sangue }\end{array}$ & 0,118 & 0,303 \\
\hline 37 & $\begin{array}{l}\text { Assento de veículo com supostas manchas de } \\
\text { sangue }\end{array}$ & 0,0001 & 0,001 \\
\hline \multirow{2}{*}{38} & A-Material subungueal & 0 & 0 \\
\hline & B-Ossos da mão da vítima & 0,136 & 0 \\
\hline \multirow{2}{*}{39} & A-Coágulos de sangue coletados em piso & 0,822 & 0 \\
\hline & B-Coágulos de sangue coletados em porta & 0,017 & 0,0014 \\
\hline 40 & Lâmina contendo secreção nasal & 0,00026 & 0 \\
\hline \multirow{2}{*}{41} & A-Camiseta com manchas de sangue & 0,186 & 0,545 \\
\hline & B-Sangue coletado de cadáver & 0,171 & 0,961 \\
\hline \multirow[t]{2}{*}{42} & $\begin{array}{c}\text { Óculos de sol com eventuais células de } \\
\text { descamação }\end{array}$ & 0,0001 & 0,0087 \\
\hline & A-Material subungueal coletado do cadáver 1 & 0,189 & 0 \\
\hline \multirow[t]{3}{*}{43} & B-Sangue coletado do cadáver 1 & 0,418 & 0 \\
\hline & C-Sangue coletado do cadáver 2 & 0,494 & 0 \\
\hline & A-Estofamento de veículo & 0,013 & 0,079 \\
\hline 44 & $\begin{array}{l}\text { B-Tapete de borracha de veículo com } \\
\text { supostas manchas de sangue }\end{array}$ & $\begin{array}{c}0,015 \\
0\end{array}$ & $\begin{array}{c}0,019 \\
0\end{array}$ \\
\hline \multirow[t]{2}{*}{45} & Mancha de sangue coletada de veículo & 0,137 & 0,561 \\
\hline & A-Brinco com manchas de sangue & 0,020 & 0 \\
\hline \multirow[t]{2}{*}{46} & B-Bojo de sutiã com manchas de sangue & 0,013 & 0 \\
\hline & C-Cueca com manchas de sêmen & 0,064 & 0,501 \\
\hline 47 & Mancha de sangue coletada de veículo & 0,984 & 1,486 \\
\hline 48 & Fragmento de vidro com mancha de sangue & 0,055 & 0,217 \\
\hline \multirow{2}{*}{49} & A-Gaze contendo mancha de sangue-sítio 1 & 0 & 0 \\
\hline & B-Gaze contendo mancha de sangue-sítio 2 & 0,010 & 0,026 \\
\hline \multirow{3}{*}{50} & A-Preservativo íntimo & 13,412 & 4,859 \\
\hline & B-Top feminino com manchas de sêmen & 0,004 & 0,029 \\
\hline & A-Bermuda com manchas de sangue & 0,213 & 0 \\
\hline \multirow[t]{2}{*}{51} & B-Sangue da suposta mãe & 0,939 & 0 \\
\hline & C-Sangue do suposto pai & 1,498 & 2,815 \\
\hline 52 & Bituca de cigarro com células de descamação & 0,211 & 0,684 \\
\hline 53 & Swab bucal com células epiteliais & 2,110 & 2,833 \\
\hline
\end{tabular}

Com base nos resultados das quantificações de todas as amostras foram realizados cálculos caso a caso, de forma que a quantidade de DNA utilizada em cada uma das reações multiplex fosse de aproximadamente $1 \mathrm{ng}$, com um limite de $5 \mu \mathrm{L}$ de volume para esta massa. Nos casos em que $5 \mu \mathrm{L}$ de volume não atingiram esta massa crítica, foram utilizados até $10 \mu \mathrm{L}$, duplicando-se, então, o volume final das reações de $12,5 \mu \mathrm{L}$ para $25 \mu \mathrm{L}$. Mesmo quando a quantificação resultou nula, as amostras foram submetidas às reações, com volume de $10 \mu \mathrm{L}$ do extraído, quando disponível. 
Em algumas situações não havia volume suficiente de DNA extraído para se realizar as amplificações nos dois multiplex com $10 \mu \mathrm{L}$ em cada um e utilizou-se metade do volume disponível para cada triplex.

\subsection{Amplificação das amostras para os sistemas NC01 e NC02}

4.4.1 Casos envolvendo identificação de cadáveres

Dos 19 casos forenses analisados que objetivavam a identificação de cadáveres foram amplificadas 20 amostras, tanto no sistema NC01 como no sistema NC02. Foram necessárias 5 repetições no $\mathrm{NC01}$ e 6 repetições no NC02, para confirmação de alelos ou quando os resultados obtidos na primeira amplificação foram incompatíveis com o resultado da quantificação de DNA apresentada pela amostra. Entre as 20 amostras, houve ausência total de amplificação para os seis loci polimórficos estudados em 2 amostras (06-Ossada de recémnascido e 14-Osso úmero) e obtenção de perfil parcial em outras duas (05-Osso fêmur e 13Osso fêmur). Tais resultados foram compatíveis com as quantificações de DNA obtidas para os produtos de extração destas amostras (Tabela 11).

As Figuras 18 e 19 ilustram casos representativos analisados deste grupo, juntamente com imagens dos materiais e os respectivos eletroferogramas obtidos nas reações NC01 e $\mathrm{NC} 02$.

A Tabela 14 demonstra os resultados obtidos nas amplificações das amostras relacionadas com identificação de cadáveres e os respectivos alelos para cada locus polimórfico estudado. 


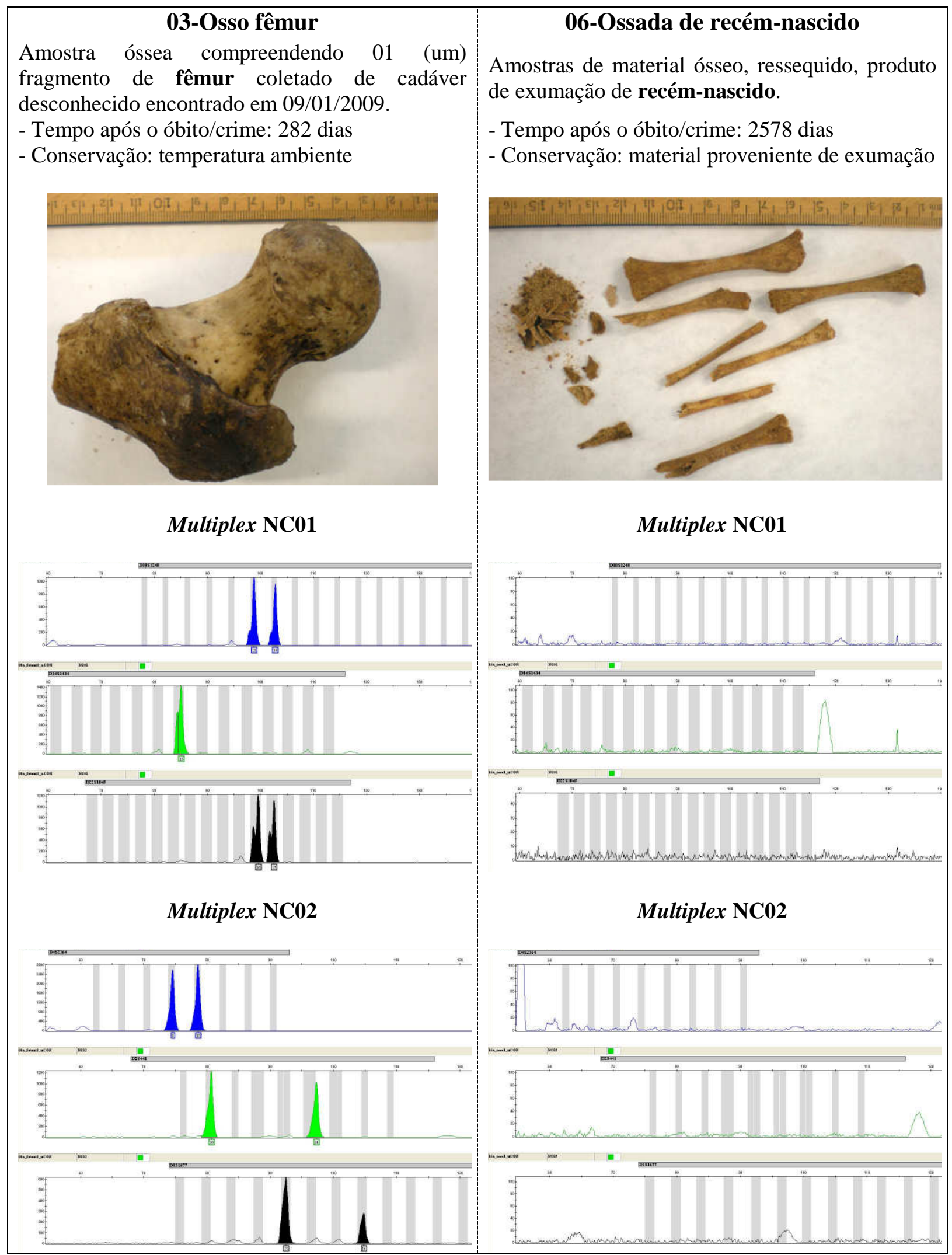

Figura 18 - Descrição do material, ilustração fotográfica e eletroferogramas obtidos após a amplificação das amostras 03-Osso fêmur e 06-Ossada de recém-nascido para os multiplex NC01 (loci D10S1248, D14S1434 e D22S1045) e NC02 (loci D4S2364, D2S441e D1S1677). Em azul, verde e preto, primers marcados, respectivamente, com os fluoróforos FAM, VIC e NED. Nos eletroferogramas, eixo x, tamanho em pares de bases; eixo y, unidade relativa de fluorescência (relative fluorescence unit - RFU). 


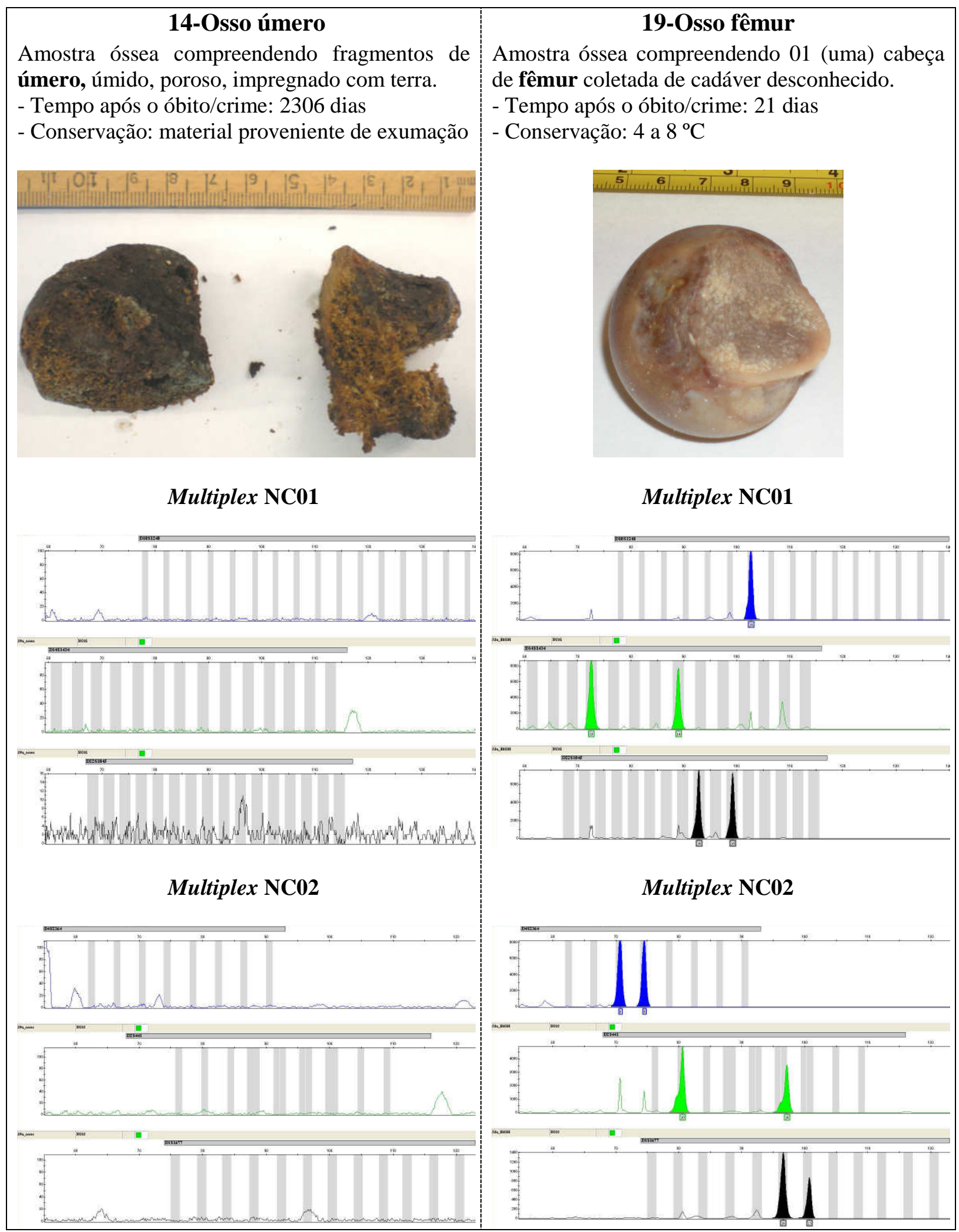

Figura 19 - Descrição do material, ilustração fotográfica e eletroferogramas obtidos após a amplificação das amostras 14-Osso úmero e 19-Osso fêmur para os multiplex NC01 (loci D10S1248, D14S1434 e D22S1045) e NC02 (loci D4S2364, D2S441e D1S1677). Em azul, verde e preto, primers marcados, respectivamente, com os fluoróforos FAM, VIC e NED. Nos eletroferogramas, eixo x, tamanho em pares de bases; eixo y, unidade relativa de fluorescência (relative fluorescence unit - RFU). 
Tabela 14 - Alelos obtidos nos microssatélites para as amostras referentes aos casos de Identificação de Cadáveres, após as reações de amplificação multiplex NC01 e NC02.

\begin{tabular}{l|ccccc|ccc}
\hline Caso & $\begin{array}{c}\text { Identificação } \\
\text { do material }\end{array}$ & $\begin{array}{c}\text { Locus } \\
\text { D1S1677 }\end{array}$ & $\begin{array}{c}\text { Locus } \\
\text { D2S441 }\end{array}$ & $\begin{array}{c}\text { Locus } \\
\text { D4S2364 }\end{array}$ & $\begin{array}{c}\text { Locus } \\
\text { D10S1248 }\end{array}$ & $\begin{array}{c}\text { Locus } \\
\text { D14S1434 }\end{array}$ & $\begin{array}{c}\text { Locus } \\
\text { D22S1045 }\end{array}$ \\
\hline $\mathbf{0 1}$ & A-Sg cad - IQ & $13 / 15$ & 10 & $8 / 9$ & $13 / 14$ & $13 / 14$ & $15 / 16$ \\
$\mathbf{0 2}$ & B-Sg cad - Ch & $13 / 15$ & 10 & $8 / 9$ & $13 / 14$ & $13 / 14$ & $15 / 16$ \\
$\mathbf{0 3}$ & Osso esterno & $13 / 15$ & $10 / 11.3$ & 9 & 13 & $13 / 14$ & 15 \\
$\mathbf{0 4}$ & Osso fêmur & $13 / 16$ & $10 / 14$ & $9 / 10$ & $13 / 14$ & 13 & $16 / 17$ \\
$\mathbf{0 5 *}$ & Osso fêmur & $12 / 13$ & $11.3 / 14$ & $9 / 10$ & $13 / 16$ & $11 / 14$ & $15 / 16$ \\
$\mathbf{0 6} * *$ & Osso fêmur & $\varnothing$ & $\varnothing$ & 10 & $\varnothing$ & 14 & $11 / 15$ \\
$\mathbf{0 7}$ & Ossada RN & $\varnothing$ & $\varnothing$ & $\varnothing$ & $\varnothing$ & $\varnothing$ & $\varnothing$ \\
$\mathbf{0 8}$ & Osso fêmur & 14 & $10 / 11$ & 8 & $13 / 15$ & $13 / 14$ & $11 / 18$ \\
$\mathbf{0 9}$ & Sg cad & $14 / 15$ & $10 / 12$ & 9 & $14 / 16$ & $10 / 14$ & $15 / 16$ \\
$\mathbf{1 0}$ & Dentes & 14 & $10 / 11$ & $9 / 10$ & $13 / 14$ & 13 & $15 / 16$ \\
$\mathbf{1 1}$ & Osso fêmur & $13 / 14$ & $10 / 15$ & $8 / 10$ & $13 / 14$ & 14 & $14 / 16$ \\
$\mathbf{1 2}$ & Osso fêmur & $13 / 15$ & $10 / 11$ & $8 / 9$ & 15 & $13 / 14$ & $15 / 16$ \\
$\mathbf{1 3} *$ & Osso fêmur & $12 / 14$ & $12 / 14$ & 9 & $12 / 15$ & 13 & 16 \\
$\mathbf{1 4} * *$ & Osso fêmur & 20 & Sug 11 & sug $8 / 9$ & sug 14 & 10 & $\emptyset$ \\
$\mathbf{1 5}$ & Múme úmero & $\varnothing$ & $\varnothing$ & $\varnothing$ & $\varnothing$ & $\varnothing$ & $\emptyset$ \\
$\mathbf{1 6}$ & Músc.cad & 14 & $12 / 15$ & 9 & $12 / 13$ & $10 / 13$ & 15 \\
$\mathbf{1 7}$ & Osso fêmur & $15 / 16$ & $11 / 14$ & $8 / 9$ & 15 & $11 / 13$ & $15 / 17$ \\
$\mathbf{1 8}$ & Osso fêmur & $12 / 15$ & $14 / 15$ & 8 & 14 & $13 / 14$ & $16 / 17$ \\
$\mathbf{1 9}$ & Osso fêmur & $14 / 15$ & 10 & $8 / 9$ & $13 / 15$ & $10 / 13$ & $15 / 16$ \\
\hline
\end{tabular}

*, perfil alélico parcial; **, ausência de amplificação em todos os loci; Sg cad, sangue de cadáver; IQ, extração realizada com o kit DNA IQ ${ }^{\mathrm{TM}}$ System (Promega Corporation, Madison/WI, EUA); Ch, Chelex, extração realizada com a resina quelante Chelex ${ }^{\circledR} 100$ (Bio-Rad, Hercules/CA, EUA); Ossada RN, ossada de recémnascido; Músc.feto, músculo de feto; Músc.cad, músculo de cadáver; $\boldsymbol{\emptyset}$, ausência de amplificação para o locus; sug, sugestivo - pico com altura menor que 50 unidades relativas de fluorescência (relative fluorescence unit RFU).

\subsubsection{Casos envolvendo crimes sexuais}

Entre os 16 casos forenses analisados relacionados com crimes sexuais foram amplificadas 30 amostras, tanto no sistema NC01 como no sistema NC02. Foram necessárias 6 repetições no $\mathrm{NC01}$ e 12 repetições no $\mathrm{NC02}$, para confirmação de alelos ou quando os resultados obtidos na primeira amplificação foram incompatíveis com o resultado da quantificação de DNA apresentada pela amostra. Entre as 30 amostras, houve ausência total de amplificação para os seis loci polimórficos estudados em 2 amostras (21-Fragmento de lençol com supostas manchas de sêmen e 23-B-Swab vaginal-FE). Nas amostras 27-Calcinha com manchas de sêmen e 28-Espátula de madeira contendo secreção vaginal, foram obtidos perfis alélicos parciais e nos casos 20-A-Swab vaginal-FE e 32-B-Cueca 2, foi observado um padrão de mistura de materiais genéticos. Houve concordância entre estes resultados, as 
quantificações (Tabela 12) e os dados anteriormente obtidos na rotina laboratorial tradicional para estas amostras.

As Figuras 20 e 21 ilustram casos representativos analisados deste grupo, juntamente com imagens dos materiais e os respectivos eletroferogramas obtidos nas reações NC01 e $\mathrm{NC} 02$.

$\mathrm{Na}$ Tabela 15 encontram-se os resultados obtidos nas amplificações das amostras relacionadas com crimes sexuais e os respectivos alelos para cada locus polimórfico estudado. 


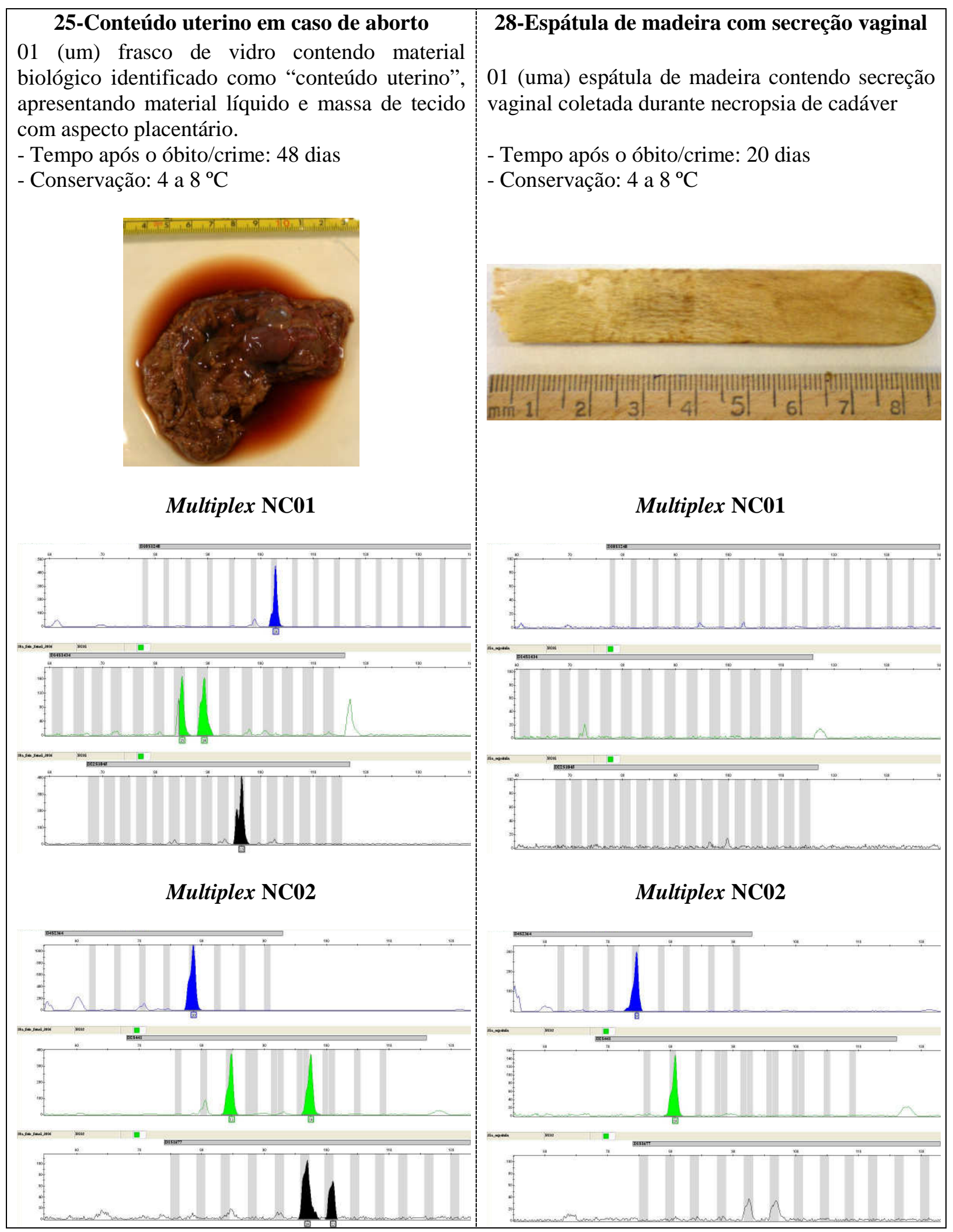

Figura 20 - Descrição do material, ilustração fotográfica e eletroferogramas obtidos após a amplificação das amostras 25-Conteúdo uterino em caso de aborto e 28-Espátula de madeira com secreção vaginal para os multiplex NC01 (loci D10S1248, D14S1434 e D22S1045) e NC02 (loci D4S2364, D2S441e D1S1677). Em azul, verde e preto, primers marcados, respectivamente, com os fluoróforos FAM, VIC e NED. Nos eletroferogramas, eixo $\mathrm{x}$, tamanho em pares de bases; eixo y, unidade relativa de fluorescência (relative fluorescence unit - RFU). 


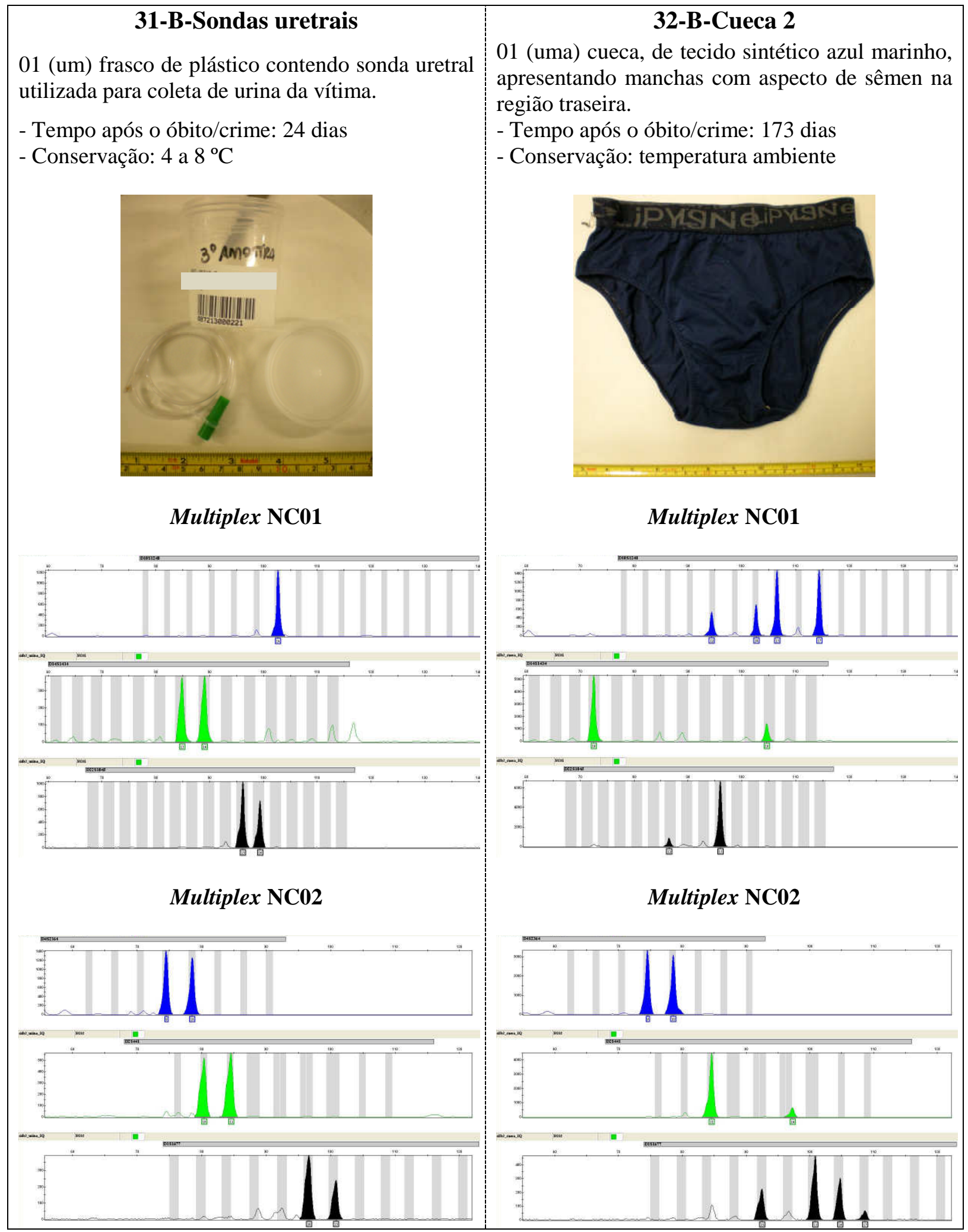

Figura 21 - Descrição do material, ilustração fotográfica e eletroferogramas obtidos após a amplificação das amostras 31-B-Sondas uretrais e 32-B-Cueca 2 para os multiplex NC01 (loci D10S1248, D14S1434 e D22S1045) e NC02 (loci D4S2364, D2S441e D1S1677). Em azul, verde e preto, primers marcados, respectivamente, com os fluoróforos FAM, VIC e NED. Nos eletroferogramas, eixo x, tamanho em pares de bases; eixo y, unidade relativa de fluorescência (relative fluorescence unit - RFU). 
Tabela 15 - Alelos obtidos nos microssatélites para as amostras referentes aos casos de Crimes Sexuais, após as reações de amplificação multiplex NC01 e NC02.

\begin{tabular}{|c|c|c|c|c|c|c|c|}
\hline \multirow[b]{2}{*}{ Caso } & \multirow{2}{*}{$\begin{array}{c}\text { Identificação do } \\
\text { material }\end{array}$} & \multicolumn{3}{|c|}{$\mathrm{NCO2}$} & \multicolumn{3}{|c|}{ NC01 } \\
\hline & & $\begin{array}{c}\text { Locus } \\
\text { D1S1677 }\end{array}$ & $\begin{array}{c}\text { Locus } \\
\text { D2S441 }\end{array}$ & $\begin{array}{c}\text { Locus } \\
\text { D4S2364 }\end{array}$ & $\begin{array}{c}\text { Locus } \\
\text { D10S1248 }\end{array}$ & $\begin{array}{c}\text { Locus } \\
\text { D14S1434 }\end{array}$ & $\begin{array}{c}\text { Locus } \\
\text { D22S1045 } \\
\end{array}$ \\
\hline \multirow[t]{2}{*}{20} & A-Swab vag.-FE*** & $14 / 15$ & $11 / 15$ & $8 / 9 / 10$ & $13 / 14 / 15$ & $13 / 14$ & $15 / 16$ \\
\hline & B-Swab vag.-FNE & $14 / 15$ & 11 & $8 / 9$ & $13 / 15$ & $13 / 14$ & 15 \\
\hline $21 * *$ & $\begin{array}{l}\text { Frag. de lençol com } \\
\text { supostas manchas de } \\
\text { sêmen }\end{array}$ & $\varnothing$ & $\varnothing$ & $\varnothing$ & $\varnothing$ & $\varnothing$ & $\varnothing$ \\
\hline \multirow[t]{2}{*}{22} & $\begin{array}{l}\text { A-Papel de filtro com } \\
\text { sec.vag.-FE }\end{array}$ & $14 / 16$ & $11 / 14$ & 9 & $13 / 14$ & 13 & $14 / 16$ \\
\hline & $\begin{array}{l}\text { B-Papel de filtro com } \\
\text { sec.vag.-FNE }\end{array}$ & $14 / 16$ & $11 / 14$ & 9 & $13 / 14$ & 13 & $14 / 16$ \\
\hline \multirow[t]{3}{*}{23} & A-Swab vaginal & $12 / 15$ & 14 & 9 & $13 / 14$ & $13 / 14$ & $11 / 15$ \\
\hline & $* *$ B-Swab vag. $-\mathrm{FE}$ & $\varnothing$ & $\varnothing$ & $\varnothing$ & $\varnothing$ & $\varnothing$ & $\varnothing$ \\
\hline & C-Swab vag.-FNE & $12 / 15$ & 14 & 9 & $13 / 14$ & $13 / 14$ & $11 / 15$ \\
\hline \multirow[t]{2}{*}{24} & A-Osso fêmur de feto & 15 & $8 / 11$ & $8 / 9$ & $14 / 17$ & 14 & $14 / 17$ \\
\hline & B-Sg do suposto pai & 15 & $8 / 11$ & $8 / 9$ & 14 & $14 / 15$ & $16 / 17$ \\
\hline 25 & $\begin{array}{l}\text { Conteúdo uterino em } \\
\text { caso de aborto }\end{array}$ & $14 / 15$ & $11 / 14$ & 10 & 14 & $13 / 14$ & 15 \\
\hline \multirow{2}{*}{$\begin{array}{l}26 \\
27 *\end{array}$} & Swab vaginal & $13 / 14$ & 14 & $8 / 9$ & $13 / 15$ & 13 & $11 / 15$ \\
\hline & $\begin{array}{l}\text { Calcinha com } \\
\text { manchas de sêmen }\end{array}$ & $\varnothing$ & $10 / 14$ & $\varnothing$ & $13 / 15$ & $13 / 14$ & $\operatorname{sug} 12 / 15$ \\
\hline $28 *$ & $\begin{array}{l}\text { Espátula de madeira } \\
\text { com sec. vaginal }\end{array}$ & $\varnothing$ & 10 & 9 & $\varnothing$ & $\varnothing$ & $\varnothing$ \\
\hline \multirow[t]{2}{*}{29} & A-Swab anal-FE & $9 / 12$ & $11.3 / 14$ & $8 / 9$ & $13 / 15$ & 10 & 11 \\
\hline & B-Swab anal-FNE & $9 / 12$ & $11.3 / 14$ & $8 / 9$ & $13 / 15$ & 10 & 11 \\
\hline \multirow[t]{2}{*}{30} & A-Swab anal-FE & $13 / 16$ & $11 / 12$ & 8 & $14 / 15$ & 13 & 16 \\
\hline & B-Swab anal-FNE & $13 / 16$ & $11 / 12$ & 8 & $14 / 15$ & 13 & 16 \\
\hline \multirow[t]{2}{*}{31} & A-Urina & $14 / 15$ & $10 / 11$ & $9 / 10$ & 14 & $13 / 14$ & $15 / 16$ \\
\hline & B-Sondas uretrais & $14 / 15$ & $10 / 11$ & $9 / 10$ & 14 & $13 / 14$ & $15 / 16$ \\
\hline \multirow[t]{2}{*}{32} & A-Cueca 1 & $15 / 16$ & 11 & $9 / 10$ & $15 / 17$ & 10 & 15 \\
\hline & B-Cueca $2 * * *$ & $13 / 15 / 16 / 17$ & $11 / 14$ & $9 / 10$ & $12 / 14 / 15 / 17$ & $10 / 18$ & $12 / 15$ \\
\hline \multirow[t]{2}{*}{33} & $\begin{array}{l}\text { A-Sg de suspeito de } \\
\text { estupro }\end{array}$ & $14 / 15$ & $11 / 14$ & $8 / 9$ & $13 / 15$ & $12 / 14$ & $12 / 15$ \\
\hline & $\begin{array}{l}\text { B-Sg de suspeito de } \\
\text { estupro }\end{array}$ & $12 / 16$ & $12 / 14$ & $8 / 9$ & $13 / 17$ & $12 / 14$ & 16 \\
\hline \multirow[t]{3}{*}{34} & A-Sg da mãe-vítima & $12 / 15$ & 13 & 8 & 13 & $13 / 16$ & $15 / 16$ \\
\hline & B-Sg da criança & $14 / 15$ & $11 / 13$ & $8 / 9$ & $13 / 15$ & $14 / 16$ & $15 / 16$ \\
\hline & $\mathrm{C}-\mathrm{Sg}$ do suposto pai & $13 / 14$ & 11 & 9 & $13 / 15$ & $10 / 14$ & $15 / 16$ \\
\hline \multirow[t]{3}{*}{35} & A-Sg da mãe-vítima & $15 / 16$ & $11 / 14$ & 9 & 14 & $12 / 13$ & $11 / 17$ \\
\hline & B-Sg da criança & $12 / 16$ & $10 / 11$ & 9 & 14 & 13 & $15 / 17$ \\
\hline & $\mathrm{C}-\mathrm{Sg}$ do suposto pai & $12 / 15$ & $11 / 14$ & 9 & $13 / 14$ & $12 / 13$ & $11 / 15$ \\
\hline
\end{tabular}

*, perfil alélico parcial; **, ausência de amplificação em todos os loci; ***, mistura de material genético; vag., vaginal; FE, Fração-Espermatozoide; FNE, Fração Não-Espermatozoide; Frag., fragmento; sec., secreção; Sg, sangue; $\boldsymbol{\emptyset}$, ausência de amplificação para o locus; sug, sugestivo - pico com altura menor que 50 unidades relativas de fluorescência (relative fluorescence unit - RFU). 
4.4.3 Casos de análise de vestígios biológicos oriundos de locais de crimes

Entre os 18 casos forenses em que foram analisados vestígios biológicos oriundos de locais de crimes, foram amplificadas 30 amostras para ambos os sistemas, NC01 e NC02. Foram necessárias 7 repetições no NC01 e 11 repetições no NC02, para confirmação de alelos ou quando os resultados obtidos na primeira amplificação foram incompatíveis com o resultado da quantificação de DNA apresentada pela amostra. Entre as 30 amostras, houve ausência total de amplificação para os seis loci polimórficos estudados em 6 amostras (37Assento de veículo com supostas manchas de sangue, 38-A-Material subungueal, 40-Lâmina contendo secreção nasal, 42-Óculos de sol com eventuais células de descamação, 44-BTapete de borracha de veículo com supostas manchas de sangue e 49-A-Gaze contendo mancha de sangue-sítio 1). Na amostra 49-B-Gaze contendo mancha de sangue-sítio 2 foi obtido um perfil alélico parcial e nos casos 43-A-Material subungueal coletado do cadáver 1 e 44-A-Estofamento de veículo foram observados padrões de mistura de materiais genéticos. Houve concordância entre estes resultados, as quantificações (Tabela 13) e os dados anteriormente obtidos na rotina laboratorial tradicional para estas amostras.

As Figuras 22 e 23 ilustram casos representativos analisados deste grupo, juntamente com imagens dos materiais e os respectivos eletroferogramas obtidos nas reações NC01 e $\mathrm{NC} 02$.

$\mathrm{Na}$ Tabela 16 encontram-se os resultados obtidos nas amplificações das amostras relacionadas com análise de vestígios biológicos de locais de crimes e os respectivos alelos para cada locus polimórfico estudado. 


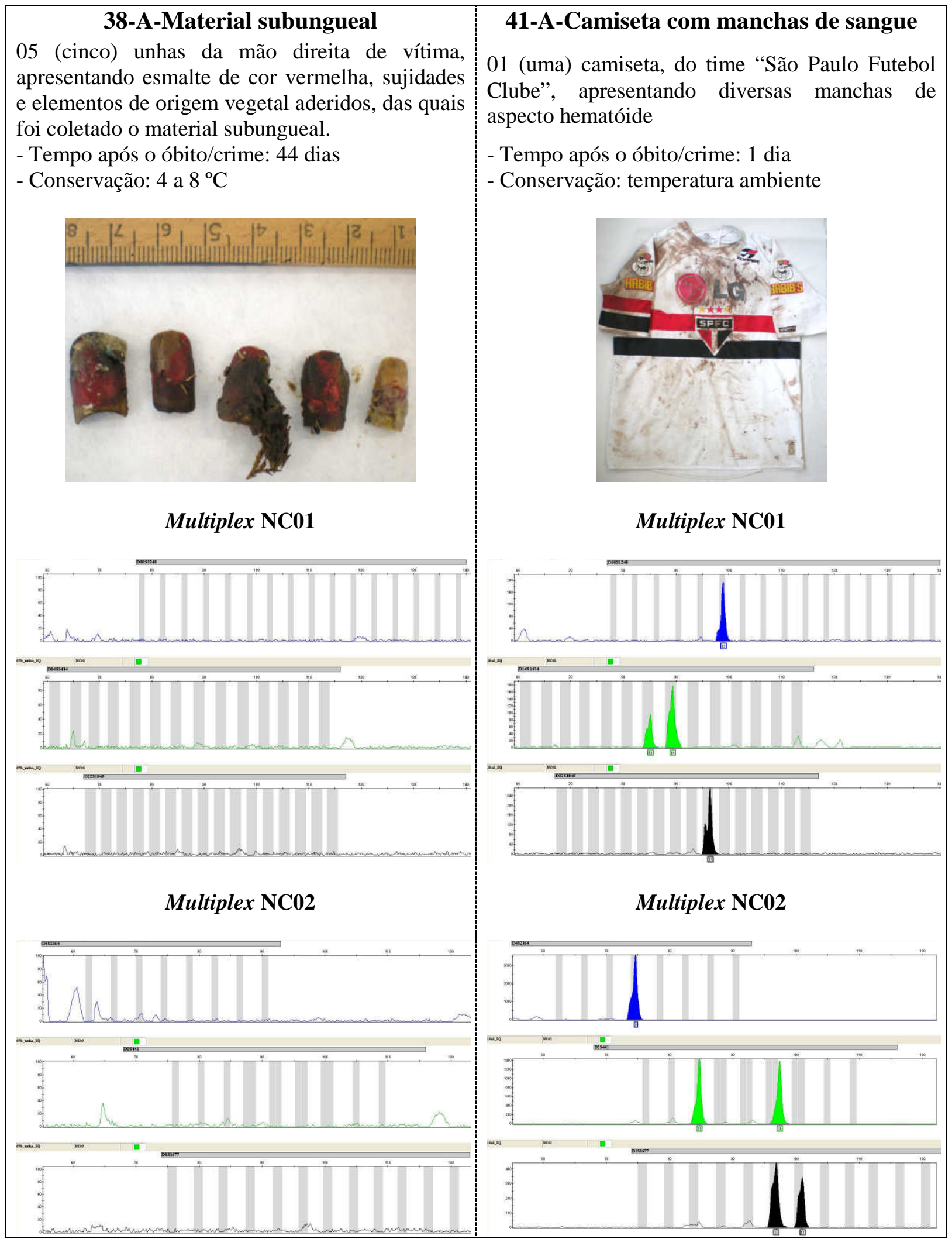

Figura 22 - Descrição do material, ilustração fotográfica e eletroferogramas obtidos após a amplificação das amostras 38-A-Material subungueal e 41-A-Camiseta com manchas de sangue para os multiplex NC01 (loci D10S1248, D14S1434 e D22S1045) e NC02 (loci D4S2364, D2S441e D1S1677). Em azul, verde e preto, primers marcados, respectivamente, com os fluoróforos FAM, VIC e NED. Nos eletroferogramas, eixo x, tamanho em pares de bases; eixo $\mathrm{y}$, unidade relativa de fluorescência (relative fluorescence unit - RFU). 


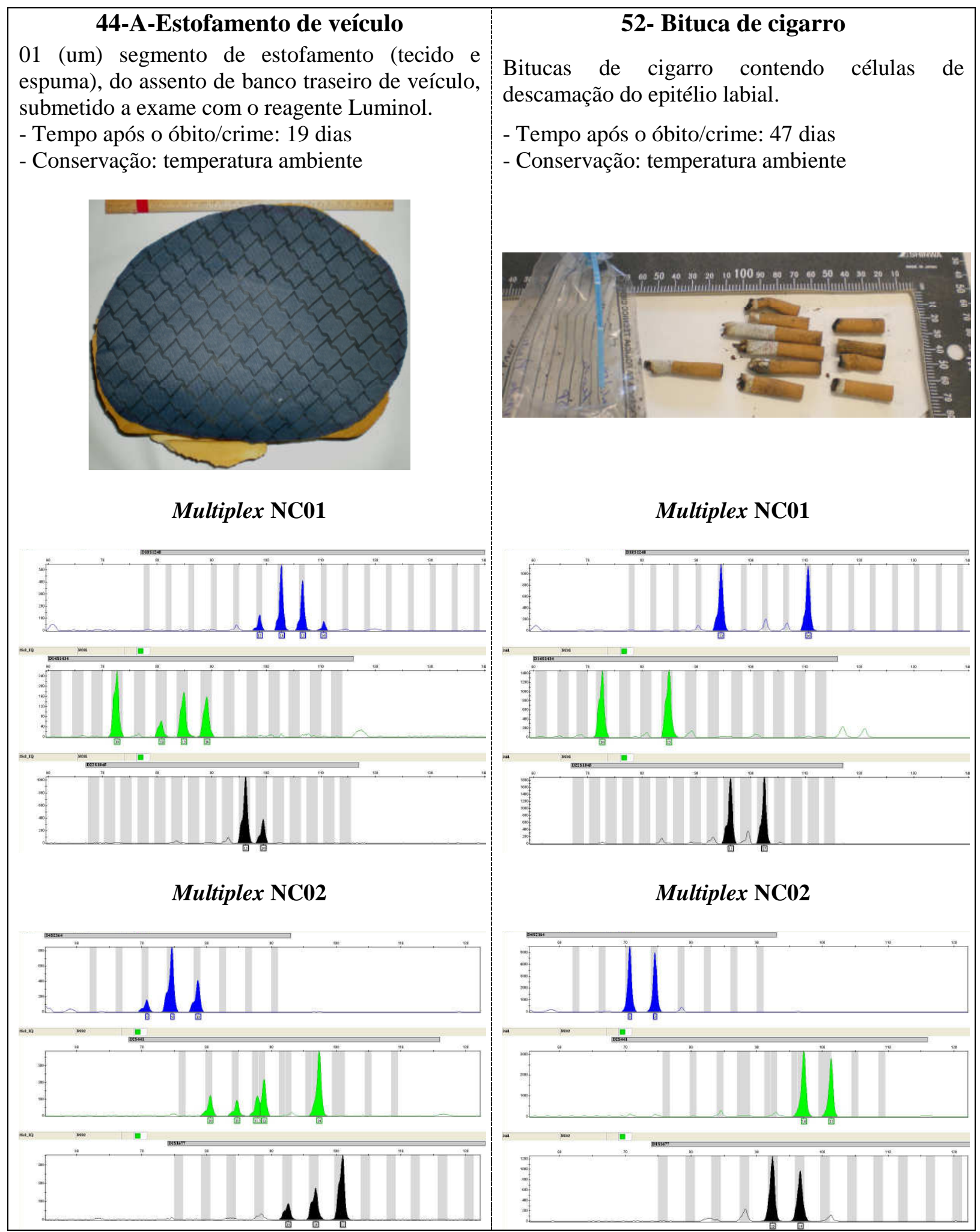

Figura 23 - Descrição do material, ilustração fotográfica e eletroferogramas obtidos após a amplificação das amostras 44-A-Estofamento de veículo e 52- Bituca de cigarro para os multiplex NC01 (loci D10S1248, D14S1434 e D22S1045) e NC02 (loci D4S2364, D2S441e D1S1677). Em azul, verde e preto, primers marcados, respectivamente, com os fluoróforos FAM, VIC e NED. Nos eletroferogramas, eixo x, tamanho em pares de bases; eixo y, unidade relativa de fluorescência (relative fluorescence unit - RFU). 
Tabela 16 - Alelos obtidos nos microssatélites para as amostras dos vestígios biológicos provenientes de locais de crimes, após as reações de amplificação multiplex NC01 e NC02.

\begin{tabular}{|c|c|c|c|c|c|c|c|}
\hline \multirow[b]{2}{*}{ Caso } & \multirow{2}{*}{$\begin{array}{c}\text { Identificação do } \\
\text { material }\end{array}$} & \multicolumn{3}{|c|}{$\mathrm{NCO2}$} & \multicolumn{3}{|c|}{ NC01 } \\
\hline & & $\begin{array}{c}\text { Locus } \\
\text { D1S1677 }\end{array}$ & $\begin{array}{c}\text { Locus } \\
\text { D2S441 }\end{array}$ & $\begin{array}{c}\text { Locus } \\
\text { D4S2364 }\end{array}$ & $\begin{array}{c}\text { Locus } \\
\text { D10S1248 }\end{array}$ & $\begin{array}{c}\text { Locus } \\
\text { D14S1434 }\end{array}$ & $\begin{array}{c}\text { Locus } \\
\text { D22S1045 }\end{array}$ \\
\hline 36 & $\begin{array}{l}\text { Frag. de camiseta } \\
\text { com manchas de sg }\end{array}$ & $13 / 14$ & 11 & $8 / 10$ & $14 / 16$ & $10 / 11$ & 16 \\
\hline $37 * *$ & $\begin{array}{c}\text { Assento de veículo } \\
\text { com sup.manchas } \\
\text { de sg }\end{array}$ & $\varnothing$ & $\varnothing$ & $\varnothing$ & $\varnothing$ & $\varnothing$ & $\varnothing$ \\
\hline \multirow[t]{2}{*}{38} & $\begin{array}{c}\text { A-Material } \\
\text { subungueal** }\end{array}$ & $\varnothing$ & $\varnothing$ & $\varnothing$ & $\varnothing$ & $\varnothing$ & $\varnothing$ \\
\hline & $\begin{array}{l}\text { B-Ossos da mão da } \\
\text { vítima }\end{array}$ & $14 / 15$ & $11 / 12$ & 9 & $13 / 14$ & $11 / 14$ & $15 / 16$ \\
\hline \multirow[t]{2}{*}{39} & $\begin{array}{l}\text { A-Coágulos de sg } \\
\text { coletados em piso }\end{array}$ & $14 / 15$ & $10 / 14$ & 9 & $15 / 16$ & $13 / 14$ & $11 / 16$ \\
\hline & $\begin{array}{l}\text { B-Coágulos de sg } \\
\text { coletados em porta }\end{array}$ & $14 / 15$ & $10 / 14$ & 9 & $15 / 16$ & $13 / 14$ & $11 / 16$ \\
\hline $40 * *$ & $\begin{array}{l}\text { Lâmina contendo } \\
\text { secreção nasal }\end{array}$ & $\varnothing$ & $\varnothing$ & $\varnothing$ & $\varnothing$ & $\varnothing$ & $\varnothing$ \\
\hline \multirow[t]{2}{*}{41} & $\begin{array}{l}\text { A-Camiseta com } \\
\text { manchas de sg }\end{array}$ & $14 / 15$ & $11 / 14$ & 9 & 13 & $13 / 14$ & 15 \\
\hline & B-Sg de cadáver & $12 / 14$ & 10 & 9 & $14 / 16$ & 14 & $11 / 16$ \\
\hline $42 * *$ & $\begin{array}{l}\text { Óculos de sol com } \\
\text { eventuais células de } \\
\text { descamação }\end{array}$ & $\varnothing$ & $\varnothing$ & $\varnothing$ & $\varnothing$ & $\varnothing$ & $\varnothing$ \\
\hline \multirow[t]{3}{*}{43} & $\begin{array}{c}\text { A-Material } \\
\text { subungueal do } \\
\text { cadáver } 1 * * *\end{array}$ & $13 / 14 / 16$ & $10 / 11 / 12 / 14$ & $8 / 9$ & $13 / 14 / 15$ & $10 / 13$ & $11 / 15 / 16$ \\
\hline & B-Sg do cadáver 1 & $13 / 16$ & $11 / 12$ & 8 & $14 / 15$ & 13 & 16 \\
\hline & C-Sg do cadáver 2 & 14 & $10 / 14$ & 9 & $13 / 14$ & $10 / 13$ & $11 / 15$ \\
\hline \multirow[t]{2}{*}{44} & $\begin{array}{l}\text { A-Estofamento de } \\
\text { veículo*** }\end{array}$ & $13 / 14 / 15$ & $10 / 11 / 11.3 / 12 / 14$ & $8 / 9 / 10$ & $13 / 14 / 15 / 16$ & $10 / 12 / 13 / 14$ & $15 / 16$ \\
\hline & $\begin{array}{c}\text { B-Tapete de } \\
\text { borracha de veículo } \\
\text { com sup. manchas } \\
\text { de sg** }\end{array}$ & $\varnothing$ & $\varnothing$ & $\varnothing$ & $\varnothing$ & $\varnothing$ & $\varnothing$ \\
\hline 45 & $\begin{array}{c}\text { Mancha de sg } \\
\text { coletada de veículo }\end{array}$ & $12 / 14$ & 14 & $8 / 9$ & $14 / 15$ & $14 / 16$ & $11 / 15$ \\
\hline \multirow[t]{3}{*}{46} & $\begin{array}{l}\text { A-Brinco com } \\
\text { manchas de sg }\end{array}$ & 14 & $10 / 14$ & 9 & $13 / 14$ & $10 / 13$ & $11 / 15$ \\
\hline & $\begin{array}{c}\text { B-Bojo de sutiã } \\
\text { com manchas de sg }\end{array}$ & 14 & $10 / 14$ & 9 & $13 / 14$ & $10 / 13$ & $11 / 15$ \\
\hline & $\begin{array}{l}\text { C-Cueca com } \\
\text { manchas de sêmen }\end{array}$ & 15 & 14 & $8 / 9$ & 14 & $10 / 14$ & $11 / 15$ \\
\hline 47 & $\begin{array}{c}\text { Mancha de sg } \\
\text { coletada de veículo }\end{array}$ & $13 / 15$ & $11 / 11.3$ & $9 / 10$ & $12 / 14$ & 13 & $11 / 16$ \\
\hline 48 & $\begin{array}{l}\text { Fragmento de vidro } \\
\text { com mancha de sg }\end{array}$ & $13 / 14$ & $10 / 14$ & 9 & $14 / 17$ & $13 / 14$ & $15 / 16$ \\
\hline \multirow[t]{2}{*}{49} & $\begin{array}{l}\text { A-Gaze contendo } \\
\text { mancha de sg-sítio } \\
\qquad 1_{* *}\end{array}$ & $\varnothing$ & $\varnothing$ & $\varnothing$ & $\varnothing$ & $\varnothing$ & $\varnothing$ \\
\hline & $\begin{array}{l}\text { B-Gaze contendo } \\
\text { mancha de sg-sítio } \\
2^{*}\end{array}$ & $12 / \operatorname{sug} 14$ & $10 / 14$ & $9 / 10$ & $13 / 15$ & sug13/14 & $11 / 17$ \\
\hline 50 & $\begin{array}{l}\text { A-Preservativo } \\
\text { íntimo }\end{array}$ & $12 / 13$ & $10 / 14$ & 9 & $13 / 14$ & $13 / 14$ & 11 \\
\hline
\end{tabular}


Tabela 16 - Alelos obtidos nos microssatélites para as amostras dos vestígios biológicos provenientes de locais de crimes, após as reações de amplificação multiplex NC01 e NC02.

\begin{tabular}{|c|c|c|c|c|c|c|c|}
\hline \multirow[b]{2}{*}{ Caso } & \multirow[b]{2}{*}{$\begin{array}{c}\text { Identificação do } \\
\text { material }\end{array}$} & \multicolumn{3}{|c|}{$\mathrm{NCO2}$} & \multicolumn{3}{|c|}{$N C 01$} \\
\hline & & $\begin{array}{c}\text { Locus } \\
\text { D1S1677 }\end{array}$ & $\begin{array}{c}\text { Locus } \\
\text { D2S441 }\end{array}$ & $\begin{array}{c}\text { Locus } \\
\text { D4S2364 }\end{array}$ & $\begin{array}{c}\text { Locus } \\
\text { D10S1248 }\end{array}$ & $\begin{array}{c}\text { Locus } \\
\text { D14S1434 }\end{array}$ & $\begin{array}{c}\text { Locus } \\
\text { D22S1045 }\end{array}$ \\
\hline 50 & $\begin{array}{l}\text { B-Top feminino } \\
\text { com manchas de } \\
\text { sêmen }\end{array}$ & $12 / 13$ & $10 / 14$ & 9 & $13 / 14$ & $13 / 14$ & 11 \\
\hline 51 & $\begin{array}{l}\text { A-Bermuda com } \\
\text { manchas de sg }\end{array}$ & $12 / 14$ & 11 & 9 & $12 / 16$ & $13 / 14$ & 15 \\
\hline & $\begin{array}{l}\text { B-Sg da sup. mãe } \\
\text { C-Sg do sup. pai }\end{array}$ & $\begin{array}{l}12 / 14 \\
14 / 16\end{array}$ & $\begin{array}{c}11 / 11.3 \\
11\end{array}$ & $\begin{array}{l}9 / 10 \\
9 / 10\end{array}$ & $\begin{array}{l}12 / 16 \\
13 / 16\end{array}$ & $\begin{array}{l}14 \\
13\end{array}$ & $\begin{array}{l}15 \\
15\end{array}$ \\
\hline 52 & $\begin{array}{l}\text { Bituca de cigarro } \\
\text { com células de } \\
\text { descamação }\end{array}$ & $13 / 14$ & $14 / 15$ & $8 / 9$ & $12 / 16$ & $10 / 13$ & $15 / 17$ \\
\hline 53 & $\begin{array}{l}\text { Swab bucal com } \\
\text { células epiteliais }\end{array}$ & 15 & $10 / 15$ & $8 / 9$ & 13 & $13 / 14$ & $11 / 15$ \\
\hline
\end{tabular}

*, perfil alélico parcial; **, ausência de amplificação em todos os loci; ***, mistura de material genético; Frag., fragmento; sg, sangue; $\boldsymbol{\emptyset}$, ausência de amplificação para o locus; sug, sugestivo - pico com altura menor que 50 unidades relativas de fluorescência (relative fluorescence unit - RFU).

\subsection{Estudo de casos}

\subsubsection{Descrição do Caso 24}

O Caso 24 está relacionado com crime Sexual e homicídio em que a vítima, que estava grávida, foi encontrada morta. O objetivo da análise de DNA foi determinar a paternidade do feto, sendo que o suposto pai era também o principal suspeito de ser o criminoso. A Figura 24 ilustra os materiais recebidos e os respectivos resultados após a amplificação para os sistemas $\mathrm{NC} 01$ e NC02.

Na análise da Figura 24 constata-se o alelo 8 no locus D2S441 que foi compartilhado por pai e filho no Caso 24 deste estudo e que foi observado mesmo após repetição dos processos de amplificação e eletroforese capilar das amostras. Este alelo não está presente nos painéis na Internet no STRBase (STRBASE, 2010) e também não foi descrito no estudo de Coble e Butler (2005). 


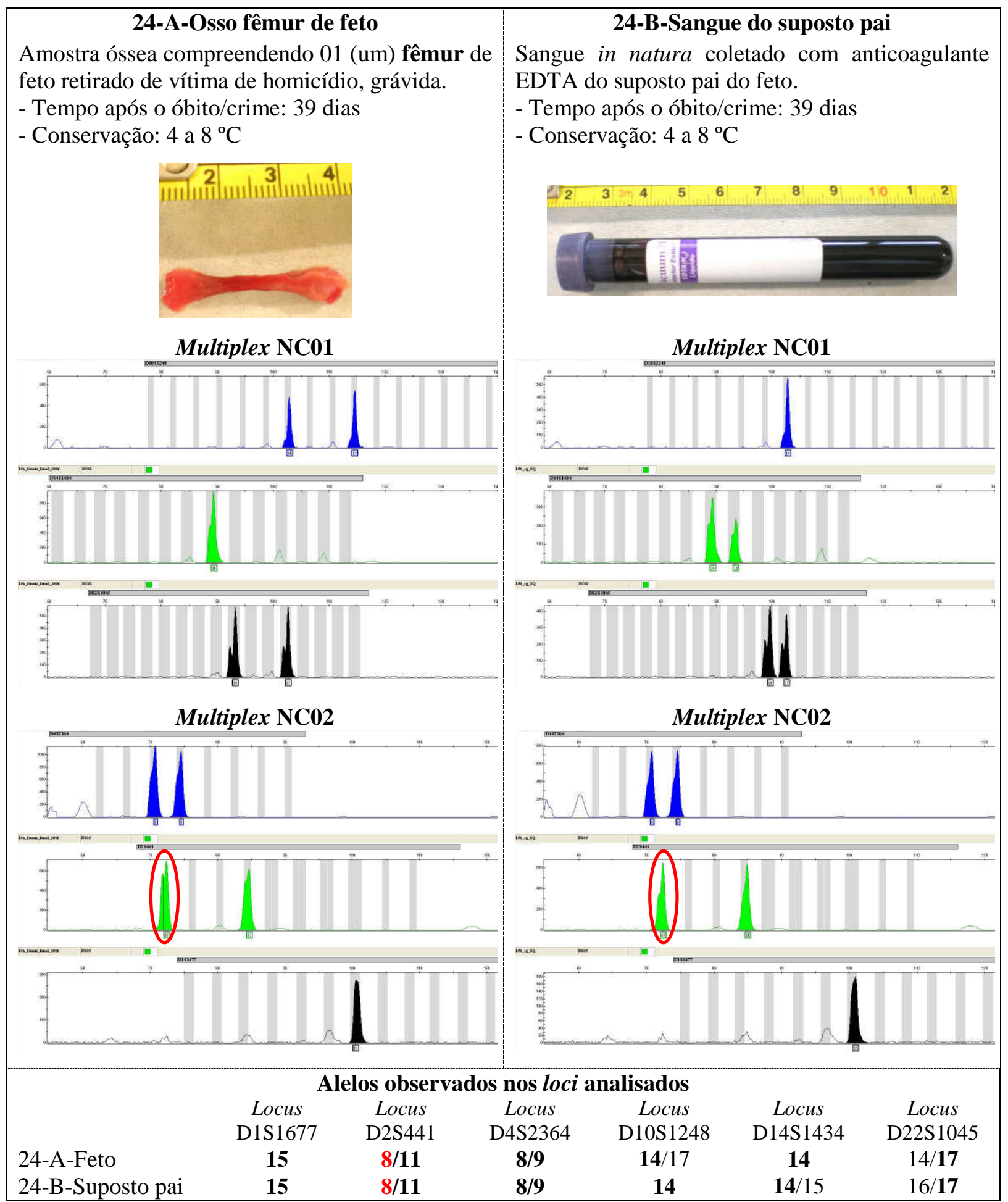

Figura 24 - Descrição do material, ilustração fotográfica, eletroferogramas e alelos obtidos após a amplificação das amostras 24-A-Osso fêmur de feto e 24-B-Sangue do suposto pai para os multiplex NC01 (loci D10S1248, D14S1434 e D22S1045) e NC02 (loci D4S2364, D2S441e D1S1677). Em azul, verde e preto, primers marcados, respectivamente, com os fluoróforos FAM, VIC e NED. Nos eletroferogramas, eixo $\mathrm{x}$, tamanho em pares de bases; eixo y, unidade relativa de fluorescência (relative fluorescence unit - RFU). Destacados em vermelho, alelos 8 observados fora do bin no locus D2S441, em ambas as amostras. 


\subsubsection{Descrição do Caso 34}

O Caso 34 refere-se a um Teste de Paternidade pós-estupro, tendo sido analisadas amostras-referência da mãe (vítima), da criança e do suposto pai (suposto estuprador). Durante a rotina laboratorial tradicional para este caso foi observada uma inconsistência entre os alelos da criança e os alelos paternos no locus D7S820, que foi considerada como uma provável mutação e nestes casos é extremamente desejável o aumento do número de regiões do DNA analisadas. A Figura 25 ilustra os materiais recebidos e os respectivos resultados após a amplificação para os sistemas NC01 e NC02.

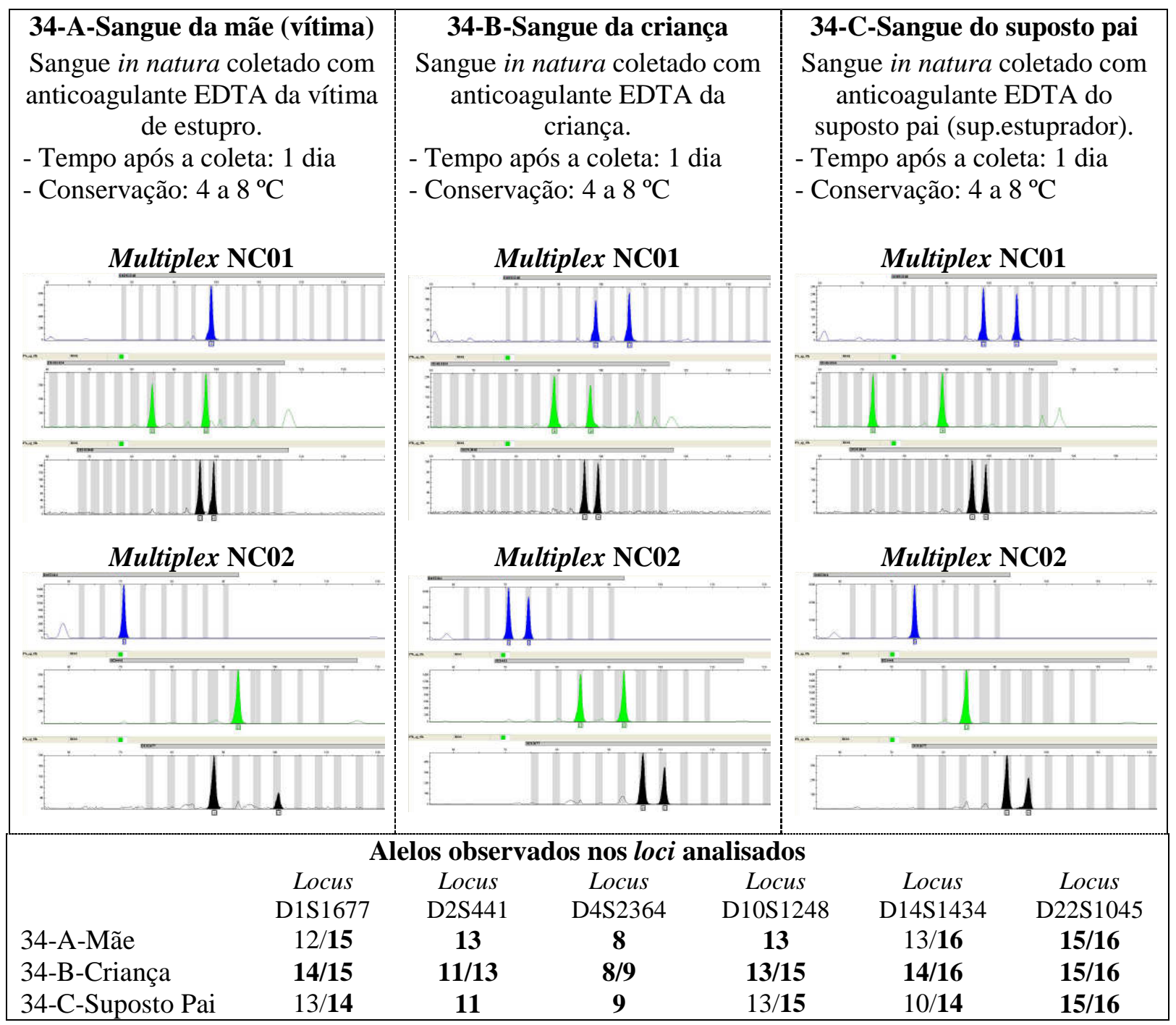

Figura 25 - Descrição do material, eletroferogramas e alelos obtidos após a amplificação das amostras 34-A-Sangue da mãe-vítima, 34-B-Sangue da criança e 34-C-Sangue do suposto pai para os multiplex NC01 (loci D10S1248, D14S1434 e D22S1045) e NC02 (loci D4S2364, D2S441e D1S1677). Em azul, verde e preto, primers marcados, respectivamente, com os fluoróforos FAM, VIC e NED. Nos eletroferogramas, eixo x, tamanho em pares de bases; eixo $\mathrm{y}$, unidade relativa de fluorescência (relative fluorescence unit - RFU). 
$\mathrm{Na}$ análise da Figura 25 constata-se a correspondência total entre os alelos maternos e paternos com relação aos alelos da criança. Tal fato corrobora a hipótese como sendo uma mutação a inconsistência observada na rotina laboratorial para o locus D7S820. Desta forma evidencia-se a utilidade dos sistemas NC01 e NC02 quando se deseja ou se faz necessário o aumento do número de regiões do DNA analisadas num dado caso forense (GOODWIN et al., 2004; COBLE; BUTLER, 2005).

\subsubsection{Descrição do Caso 51}

O Caso 51 está relacionado com um homicídio no qual durante as investigações foi encontrada uma bermuda contendo manchas de sangue na casa de um indivíduo suspeito. Pelo fato do cadáver ter sido inumado sem a coleta de amostra-referência, foi realizada a comparação do perfil alélico presente na bermuda com amostras sanguíneas-referência da suposta mãe e do suposto pai biológicos da vítima, na expectativa de se averiguar eventuais vínculos genéticos de maternidade e paternidade. Entretanto, ao longo das análises do caso, foi constatada uma possível mutação no locus D21S11, determinando que pesquisas adicionais fossem realizadas para confirmação dos achados. A Figura 26 ilustra os materiais recebidos e os respectivos resultados após a amplificação para os sistemas NC01 e NC02.

No caso 51 constatou-se correspondência total entre os alelos da suposta mãe e do suposto pai com relação aos alelos presentes na bermuda contendo manchas de sangue da vítima de homicídio (Figura 26). Tal fato corrobora a hipótese como sendo uma mutação a inconsistência observada na rotina laboratorial para o locus D21S11. Mais uma vez demonstrou-se a utilidade dos sistemas NC01 e NC02 quando se deseja ou se faz necessário o aumento do número de regiões do DNA analisadas num dado caso forense. 


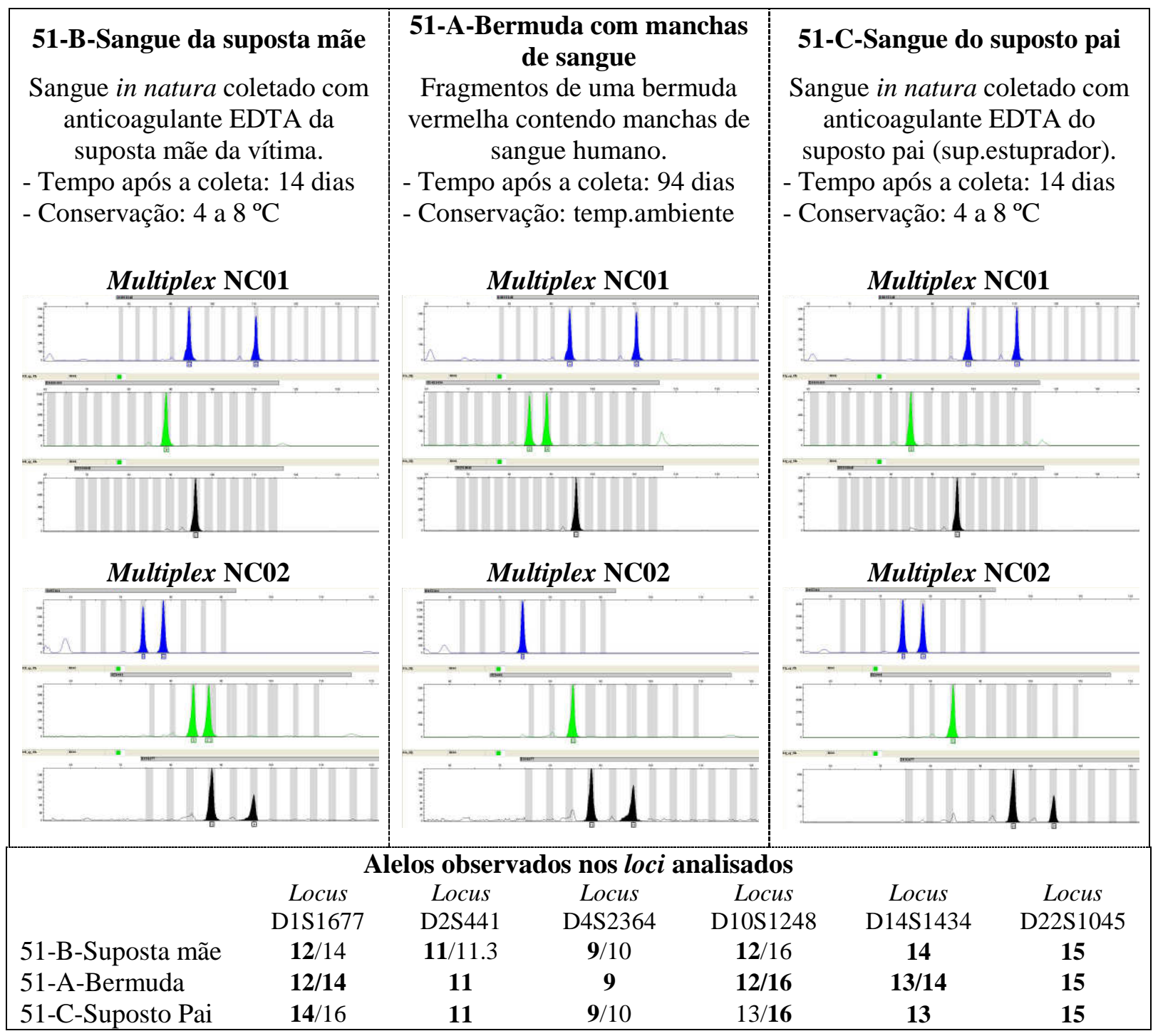

Figura 26 - Descrição do material, eletroferogramas e alelos obtidos após a amplificação das amostras 51-B-Sangue da suposta mãe, 51-A-Bermuda com manchas de sangue e 51-C-Sangue do suposto pai para os multiplex NC01 (loci D10S1248, D14S1434 e D22S1045) e NC02 (loci D4S2364, D2S441e D1S1677). Em azul, verde e preto, primers marcados, respectivamente, com os fluoróforos FAM, VIC e NED. Nos eletroferogramas, eixo x, tamanho em pares de bases; eixo y, unidade relativa de fluorescência (relative fluorescence unit - RFU). temp.ambiente, temperatura ambiente.

\subsubsection{Descrições dos Casos 43 e 46}

Os casos 43 e 46 referem-se a um mesmo evento criminal, um duplo homicídio de duas adolescentes. Inicialmente foram enviados para análise o material subungueal da vítima 1 (43-A-Material subungueal do cadáver 1) e as amostras-referência coletadas dos cadáveres das vítimas 1 e 2 (43-B-Sangue do cadáver 1 e 43-C-Sangue do cadáver 2). Em posteriores buscas durante a investigação de possível local relacionado com os fatos foram coletados e 
encaminhados para análises um brinco (46-A-Brinco com manchas de sangue), um bojo de sutiã (46-B-Bojo de sutiã com manchas de sangue) e uma cueca (46-C-Cueca com manchas de sêmen). Na execução das análises laboratoriais, verificou-se a presença de mistura de materiais genéticos no conteúdo subungueal. A Figura 27 ilustra os materiais recebidos e os respectivos resultados após a amplificação para os sistemas NC01 e NC02.

Conforme constatado na rotina laboratorial, para os sitemas $\mathrm{NC01}$ e NC02, o conteúdo sob as unhas da vítima 1 também foi sugestivo de uma mistura de células das vítimas 1 e 2 . No brinco e no bojo de sutiã, de acordo com o esperado, foi observado um perfil alélico característico da vítima 2 e, por fim, na cueca, foi verificado um perfil de DNA, que não apresenta relação com nenhuma das vítimas (Figura 27).

Este caso demonstrou a aplicabilidade dos sistemas avaliados em casos de misturas de materiais, de acordo com as recomendações para análises de miniSTRs "non-CODIS" (COBLE et al., 2006; GILL et al., 2006; OPEL et al., 2007; PARSONS et al., 2007; LOPES et al., 2009). 


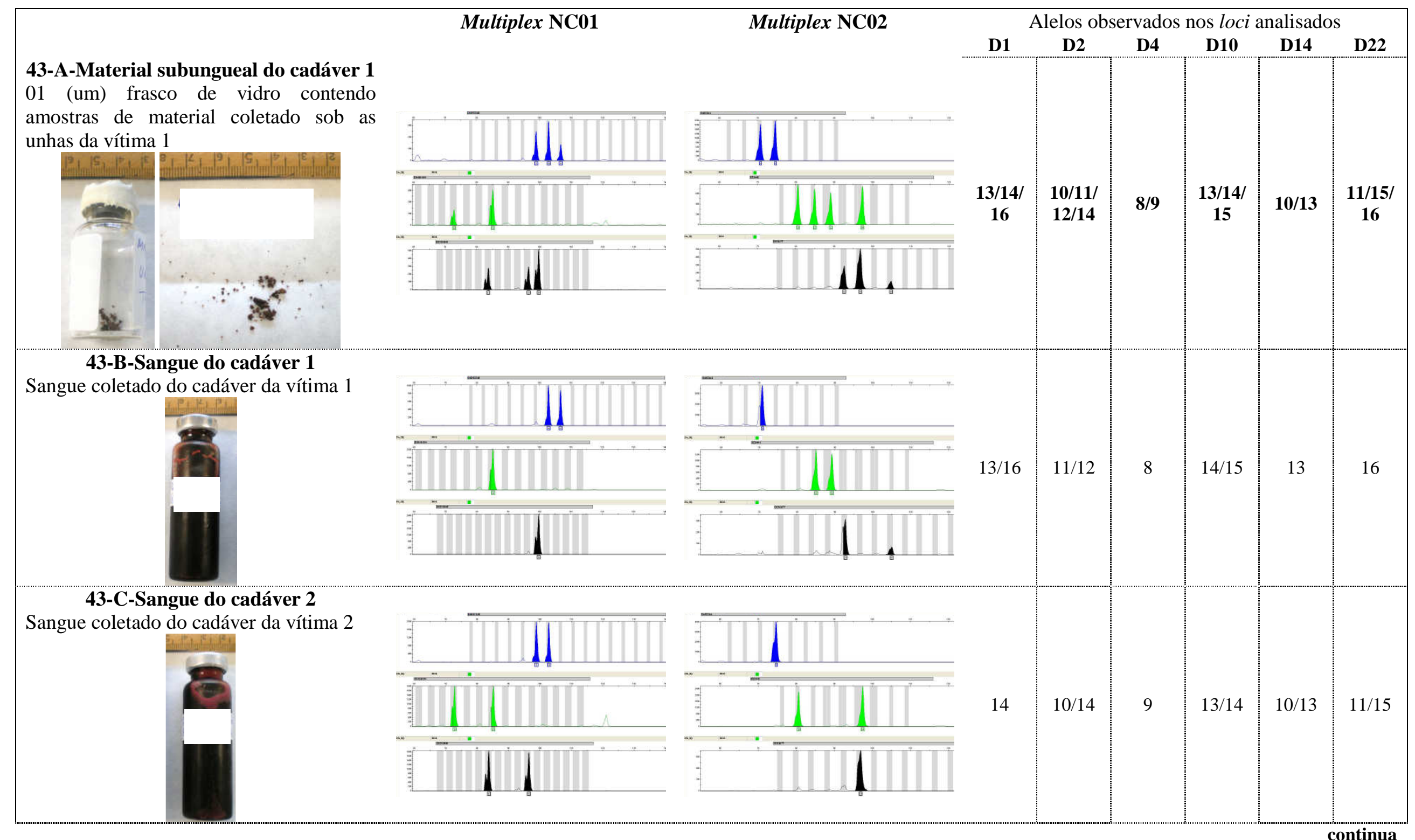


continuação

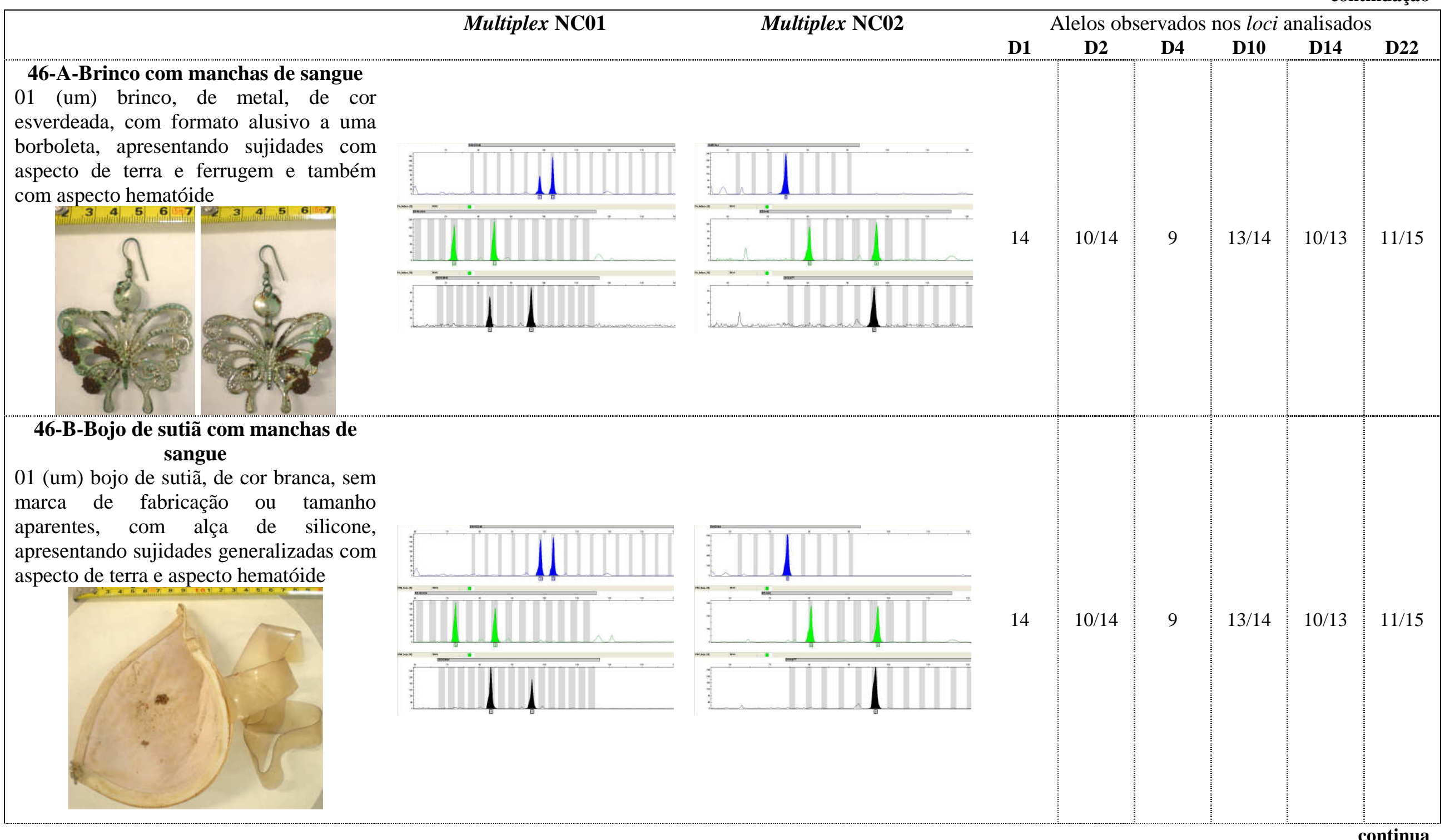


conclusão

\section{6-C-Cueca com manchas de sêmen}

01 (uma) cueca, de cor azul, confeccionada em tecido de algodão, contendo as inscrições "Tondo" na região do elástico, apresentando sujidades generalizadas com aspecto de terra, manchas no tecido e diversas regiões rasgadas, recebida úmida
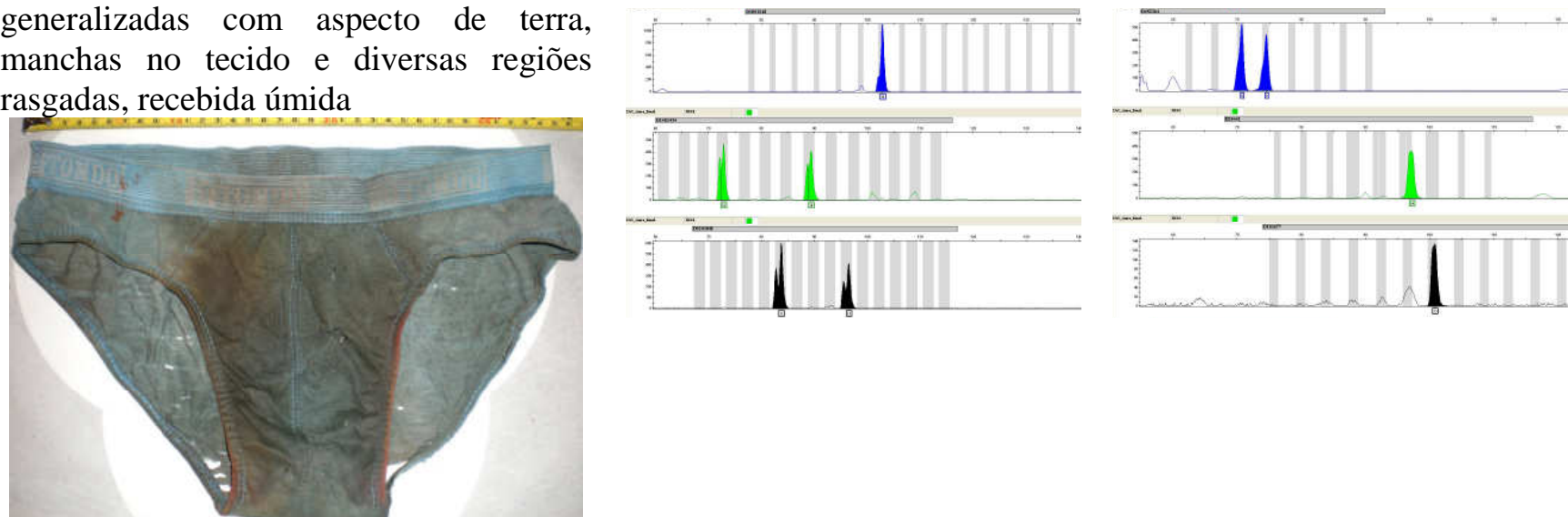

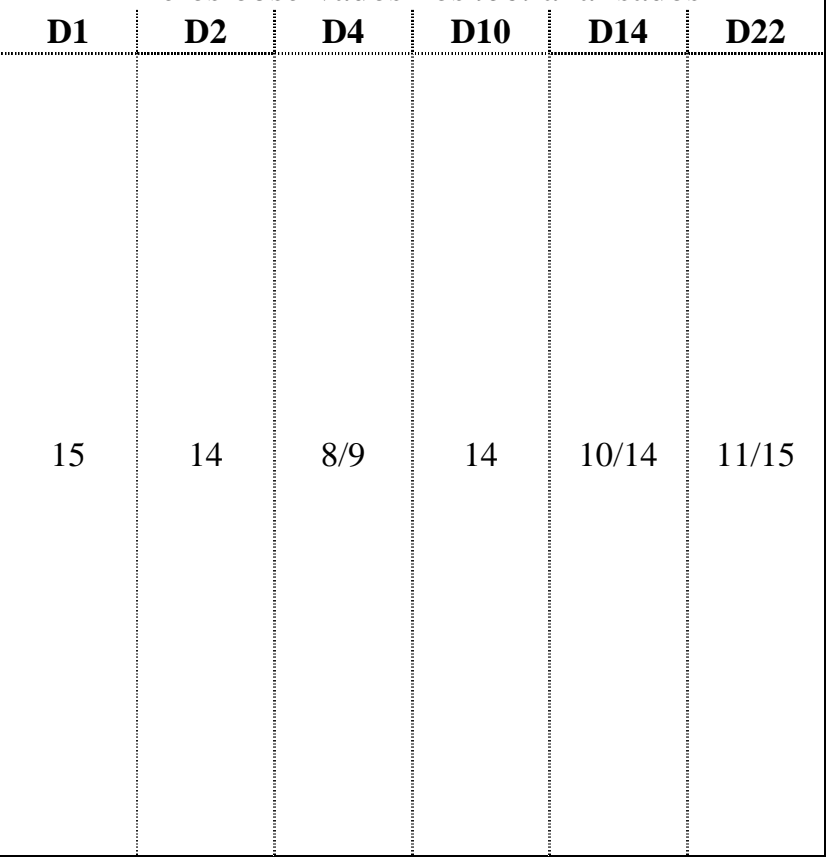

Figura 27 - Descrição do material, ilustração fotográfica, eletroferogramas e alelos obtidos após a amplificação das amostras 43-A-Material subungueal do cadáver 1, 43-B-Sangue do cadáver 1, 43-C-Sangue do cadáver 2, 46-A-Brinco com manchas de sangue, 46-B-Bojo de sutiã com manchas de sangue e 46-C-Cueca com manchas de sêmen para os multiplex NC01 (loci D10S1248, D14S1434 e D22S1045) e NC02 (loci D4S2364, D2S441e D1S1677). Em azul, verde e preto, primers marcados, respectivamente, com os fluoróforos FAM, VIC e NED. Nos eletroferogramas, eixo $\mathrm{x}$, tamanho em pares de bases; eixo y, unidade relativa de fluorescência (relative fluorescence unit - RFU). 


\subsection{Comparação de genótipos}

Para a avaliação simultânea dos alelos obtidos para as seis regiões polimórficas e para todas as categorias de casos analisadas, foram desconsideradas as ausências de amplificação, os perfis parciais, os perfis de mistura de DNA e as amostras que sabidamente eram de mesma procedência biológica resultando num total de 50 perfis alélicos.

Estes 50 genótipos (conjunto dos alelos dos loci D1S1677, D2S441, D4S2364, D10S1248, D14S1434 e D22S1045) foram comparados entre si e não houve coincidência. Apesar desta amostragem para comparação de genótipos não ser a ideal, os dados sugerem uma frequência genotípica menor do que 2\% (1 em 50) para a utilização conjunta dos sitemas $\mathrm{NC} 01$ e NC02. 
5 DISCUSSÃO 
Nenhuma sociedade poderá existir na qual cada indivíduo não tenha sua identidade assegurada, que o distingua, pessoalmente, nas suas relações comuns. Assim, a identificação dos indivíduos tornou-se imprescindível em todas as esferas das relações humanas, seja ao nível social como jurídico. Através desta identificação, as pessoas podem preservar seus direitos, bem como ter seus deveres cobrados, tanto na esfera cível, quanto na esfera penal. A identidade de uma pessoa se faz necessária mesmo após o seu falecimento, para assegurar os direitos familiares e a própria destinação de seu corpo (PENA, 1997).

Pode-se dizer que a análise de DNA revolucionou o campo da identificação humana. A necessidade de apenas uma pequena quantidade de amostra, a estabilidade da molécula e o alto grau de exatidão e precisão contribuíram para a aplicação desta tecnologia em testes criminais e de paternidade, em estudos populacionais, análises médicas e em aplicações agrícolas e melhoramento animal (JOBLING; GILL, 2004).

Durante as últimas décadas, a transição entre as tipagens convencionais de DNA através da análise de VNTRs para as identificações baseadas no método de estudo de microssatélites STRs com o uso da reação de PCR geraram uma série de tecnologias ainda mais sensíveis e extremamente úteis. Estas técnicas de identificação com a utilização de regiões polimórficas do DNA já estão bem estabelecidas como um processo seguro, com alto poder de discriminação e alta confiabilidade, sendo aceitas como prova legal em casos judiciais, criminais e cíveis, que envolvam identificação humana (MORETTI et al., 2001; MOURA NETO, 1998).

Desde março de 1999 o Instituto de Criminalística de São Paulo (IC) disponibilizou oficialmente os serviços de seu Laboratório de DNA. Além de pretender auxiliar nas análises antropológicas para identificação de cadáveres realizadas pelo Instituto Médico Legal de São Paulo (IML), a implantação deste laboratório teve por objetivo principal oferecer à investigação policial e judicial elementos que pudessem objetivamente contribuir não apenas para a exclusão de suspeitos, mas para a determinação da autoria de crimes cometidos (BONACCORSO, 2005).

Desde sua fundação até junho de 2010, foram recebidos aproximadamente 4.100 casos, resultando na análise de mais de 10.000 perfis genéticos. As formas de apresentação dos materiais biológicos recebidos para análise são variadas e objetivam o auxílio na elucidação de crimes. Como representante de parte da comunidade forense nacional, o Laboratório de DNA do Instituto de Criminalística do Estado de São Paulo enfrenta em sua rotina laboratorial as mesmas dificuldades já mencionadas, com relação à qualidade das amostras submetidas à análise e às configurações dos confrontos genéticos realizados, que 
ocasionam a necessidade em diversos de seus casos de um aumento do número de regiões do DNA analisadas, com maior sensibilidade para amostras degradadas, sendo extremamente recomendada a introdução dos miniSTRs "non-CODIS" em sua rotina de trabalho; um dos objetivos analisados neste trabalho.

No presente estudo, avaliou-se o emprego de seis regiões polimórficas do tipo microssatélites, "non-CODIS", divididas em duas reações de PCR do tipo triplex, sendo no sistema denominado NC01 ("non-CODIS 01") amplificados simultaneamente os loci D10S1248, D14S1434 e D22S1045 (localizados, respectivamente, nos braços longos dos cromossomos 10, 14 e 22) e no sistema denominado NC02 ("non-CODIS 02") os loci D1S1677 (localizado no braço longo do cromossomo 1), D2S441 (localizado no braço curto do cromossomo 2) e D4S2364 (localizado no braço longo do cromossomo 4), de acordo com o proposto em 2005 por Coble e Butler. Estes loci apresentam transmissão genética independente entre si e também não estão ligados aos 13 microssatélites do CODIS, sendo, entretanto, comparáveis a estes últimos em termos de heterozigozidade (HILL et al., 2008), com taxas de mutação ligeiramente menores (VALLONE et al., 2007), o que sugere que serão STRs úteis como complementos nas análises de DNA de amostras forenses.

Inicialmente procedeu-se à validação dos primers adquiridos para cada uma das regiões polimórficas, segundo sequências e fluoróforos sugeridos em 2005 por Coble e Butler. Para esta validação foram realizadas reações de PCR exclusivas para cada par de iniciadores, utilizando-se amostras dos DNA controles 9947A, 9948, ABI007 e K562, na concentração de 1ng por reação. Estes controles foram selecionados devido ao fato de existirem publicados os alelos esperados para cada um dos loci deste trabalho no Banco de dados de STRs na Internet - STRBase (STRBASE, 2010). Paralelamente, os primers foram validados para sua utilização no formato multiplex, nas reações $\mathrm{NC01}$ e NC02, utilizando-se como referência as mesmas amostras de DNA controle, com genótipos esperados previamente publicados para cada um dos loci.

Como pode ser observado destacado nas Figuras 13 e 15, para o locus D14S1434 obtivemos picos inespecíficos para todos os DNA controles utilizados, tanto na validação individual dos primers, como no formato multiplex NC01. Em alguns experimentos a intensidade da fluorescência para estes picos inespecíficos foi até maior do que a dos próprios alelos esperados. O aparecimento destes picos pode ocorrer devido a incompatibilidade da combinação dos primers utilizados e/ou à ligação inespecífica destes a porções aletórias do genoma alvo (HILL; BUTLER; VALLONE, 2009). Desconsideramos a possibilidade de contaminação dos controles de DNA utilizados, já que se isto tivesse ocorrido teriam sido 
observados estes picos extras também para os outros loci. Além da repetição das reações de amplificação, infrutíferas, solicitamos a nova síntese do referido par de primers junto ao fabricante Applied Biosystems. Após o recebimento das moléculas ressintetizadas, todo o processo foi realizado novamente e os resultados obtidos foram os mesmos. Tal fato nos levou a considerar a hipótese da formação destes produtos inespecíficos ser realmente decorrente da sequência inadequada dos iniciadores.

Estas ocorrências não foram reportadas por Coble e Butler (2005) em seu relato de validação, mas quando se desenvolvem estratégias para o estudo de regiões polimórficas com o emprego da reação de PCR e principalmente quando se realizam estudos simultâneos de microssatélites através de reações multiplex é comum serem enfrentadas dificuldades devido à incompatibilidade da combinação dos primers utilizados, da ligação inespecífica destes a porções aletórias do genoma alvo e do balanceamento incorreto entre as quantidades dos reagentes que podem gerar adenilação incompleta, produtos inespecíficos e artefatos indesejáveis (HILL; BUTLER; VALLONE, 2009; HILL et al., 2008).

Em detrimento da opção de selecionar outras sequências para os primers, o que poderia acarretar esforços de padronização além dos desejados, optou-se pela estratégia de minimização do problema, com o emprego do QIAGEN ${ }^{\circledR}$ Multiplex PCR Kit (QIAGEN, Hilden, Alemanha). Este kit comercial é composto de uma mistura de enzima, tampão e desoxinucleotídeos trifosfato (HotStarTaq ${ }^{\circledR}$ DNA Polymerase, Multiplex PCR Buffer com $6 \mathrm{mM}$ de $\mathrm{MgCl}_{2}$ e dNTP Mix - QIAGEN, Hilden, Alemanha) e é apropriado para reações do tipo multiplex já que as proporções pré-definidas de seus componentes asseguram a eficiência no anelamento e extensão de todos os primers presentes na reação, com alta especificidade (QIAGEN, 2010). Com o uso destes reagentes houve melhoria da qualidade dos resultados, principalmente para o locus D14S434 e foi possível observar a redução na intensidade da fluorescência dos picos inespecíficos/artefatos, que apesar de não terem sido completamente eliminados apresentaram-se em condições de risco muito menor de serem confundidos com os reais alelos das amostras (Figura 16).

A Figura 17 demonstra que para o triplex $\mathrm{NC02}$, obtivemos resultados satisfatórios nas amplificações dos DNA controles, exceto pelo desbalanço nos picos referentes aos alelos 13 e 14, no locus D1S1677, para o controle K562. Este desbalanço ocorreu mesmo após repetições da reação de PCR, mas optamos por continuar os estudos e observar o comportamento das amostras forenses a serem amplificadas.

Em vários eletroferogramas (Figuras 15, 16 e 17), foram observados alguns sinais fluorescentes, com formato ligeiramente diferente quando comparados com os picos, mais 
calibrosos e arredondados, que consideramos como sendo prováveis "dye blobs", que são artefatos do próprio fluoróforo, quando as moléculas deste se dissociam do oligonucleotídeo e migram independentemente no inteiror do capilar durante a eletroforese (BUTLER, 2005).

Durante o processo de validação (Figuras 9 a 17), foram observados em todos os microssatélites, picos de intensidade de fluorescência reduzida, com tamanho aproximado de uma repetição do STR a menos do que o alelo real amplificado, características dos "stutters". Os stutters em geral, no caso de polimorfismos de tetranucleotídeos, tem intensidade de até $15 \%$ da intensidade do alelo realmente presente no locus e ocorrem devido à "derrapagem" da polimerase na fita molde no momento da amplificação (BUTLER, 2005). A ocorrência destes picos é esperada e considerada normal nas reações de amplificação de STRs, mas deve ser muito cautelosamente avaliada nos casos em que se analisam misturas de DNA, para que não sejam confundidos os stutters com alelos de contribuintes minoritários da mistura (WEIR et al., 1997; GILL; SPARKES; BUCKLETON, 1998; LADD et al., 2001). Picos característicos de processo de adenilação incompleta (pico -A) também foram observados durante o processo de validação realizado e ocorrem comumente nas reações de amplificação de microssatélites, principalmente nos casos em que a quantidade de DNA e o balancemanto dos reagentes da reação não estão adequados (BUTLER, 2005).

O fato de não haver disponível para este trabalho uma escada alélica para os sitemas amplificados determinou que os ajustes das faixas de tamanhos esperados para os alelos (bins - em pares de bases), devido a diferenças entre equipamentos, reagentes e condições da eletroforese capilar, em relação às disponíveis na internet no STRBase (STRBASE, 2010), fossem realizados com bases nos alelos conhecidos para cada um dos DNA controle utilizados na fase de validação dos primers e dos multiplex NC01 e NC02.

Foram, então, padronizadas as condições de reação para cada um dos sistemas NC01 e NC02, com modificações em relação à publicação de Coble e Butler (2005), de acordo com as necessidades do Laboratório de DNA do Instituto de Criminalística do Estado de São Paulo.

Diferentes amostras biológicas enviadas ao longo do ano de 2009 à análise forense de DNA no Laboratório de DNA do Núcleo de Biologia e Bioquímica do Instituto de Criminalística do Estado de São Paulo e atribuídas à perita criminal autora deste trabalho foram objetos deste estudo. Entre os 53 casos analisados, 19 objetivaram identificação de cadáveres, 16 foram correspondentes a crimes sexuais e os 18 restantes envolveram a análise de vestígios biológicos oriundos de locais de crimes. No total, foram avaliadas 80 amostras de DNA extraídos, sendo 71 amostras-questionadas e 09 amostras-referência de vítimas, suspeitos ou familiares relacionados. As diferentes amostras, de acordo com o tipo de caso, 
foram classificadas segundo os critérios de tipo de material, tempo decorrido após o óbito ou após o crime até o recebimento no laboratório, condições de conservação do material no período antes do seu recebimento e grau de carbonização, quando aplicável (Tabelas 1, 2 e 3).

As amostras forenses analisadas foram coletadas por peritos criminais ou médicos legistas segundo as normas presentes na Resolução SSP-SP 194 de 2 de junho de 1999 (SÃO PAULO, 1999b), que preconizam os cuidados para se garantir a preservação das amostras biológicas que serão submetidas à extração e subsequente análise de DNA. A adoção destas recomendações nos procedimentos de coleta visa também evitar a contaminação das amostras por DNA exógeno, o que é bastante relevante quando se trata da reação de PCR, que em tese poderia promover a amplificação do DNA de uma única célula, mesmo estando esta molécula parcialmente degradada (WALKER; RAPLEY, 1999; INTERPOL, 2001; STRACHAN; READ, 2002). O tempo entre a ocorrência do crime e/ou óbito do indivíduo e a coleta do material nos casos estudados variou entre 1 e 2578 dias (Tabelas 1, 2 e 3). Em 4 dos 19 casos relacionados com identificação de cadáveres, o material biológico foi coletado em processo exumatório, sendo que nestas ocasiões foram observados os maiores lapsos temporais entre o óbito e a análise laboratorial (2578, 2577, 2306 e 1314 dias, respectivamente). Tais valores foram consistentes com as maiores dificuldades de obtenção dos resultados e/ou a necessidade de maiores processos de repetição para estas amostras, conforme esperado em vista das piores condições de conservação da molécula de DNA nestes espécimes (CHUNG et al., 2004; PARSONS et al., 2007). Amostras relacionadas com crimes sexuais ou coletadas em locais de crimes não tiveram o fator tempo como limitante, pelo fato das coletas terem sido realizadas em datas próximas dos respectivos eventos criminais, tendo sido os materiais corretamente conservados e acondicionados antes das análises laboratoriais propriamente ditas, segundo as recomendações pré-estabelecidas.

A extração do DNA para cada tipo de material biológico obedeceu aos diversos protocolos já previamente estabelecidos e em uso rotineiro no Laboratório de DNA do Instituto de Criminalística do Estado de São Paulo (Tabela 4). As amostras selecionadas para este estudo corresponderam aos melhores exemplares de DNA extraídos, não sendo incluídas todas as repetições de tentativas de extração de cada uma das amostras.

Em 5 dos 16 casos de crimes sexuais, o método de extração de DNA utilizado foi o conhecido como extração diferencial de DNA, modificado a partir do proposto inicialmente por Gill e colaboradores em 1985. As metodologias de extração diferencial de DNA têm a capacidade de separar as células epiteliais dos espermatozoides, baseando-se na diferença de resistência das membranas celulares a agentes que promovem a lise destes tipos celulares. As 
extrações diferenciais são comumente utilizadas em laboratórios forenses para separar os espermatozoides das células vaginais, em amostras de estupro contendo uma mistura de DNA feminino e masculino, permitindo, portanto, a identificação de células exclusivas do estuprador, numa população celular predominantemente feminina. Há que se considerar, entretanto, que esta abordagem apresenta limitações, nos casos de estupradores vasectomizados ou azoospérmicos (RAPLEY; WHITEHOUSE, 2007).

Após o processo de extração de DNA, as amostras foram quantificadas por PCR em Tempo Real. É extremamente recomendável que se realize o processo de quantificação do DNA extraído de amostras forenses e que serão submetidos a métodos de genotipagem baseados na reação de PCR para se prevenir falhas na amplificação devido à ausência de DNA, evitando-se também artefatos de PCR como a ausência de amplificação de um dado alelo (allele dropout) produzida por efeitos estocásticos da amplificação de amostras com quantidades menores do que 100pg de DNA, conhecidas como amostras com baixo número de cópias (LCN - low copy number) (GILL, 2001; WHITAKER; COTTON; GILL, 2001). A quantificação da amostra ainda previne a obtenção de artefatos de excesso de amplificação, como os sinais fluorescentes acima de valores aceitáveis (off-scale peaks), adenilação incompleta, stutters com alturas além das esperadas e interferências nos picos dos eletroferogramas gerados por diferentes fluoróforos, em diferentes comprimentos de onda (pullout). A exatidão na quantificação auxilia também na economia laboratorial, evitando-se o desperdício de reagentes e principlamente de amostras exíguas (RAPLEY; WHITEHOUSE, 2007; GILL et al., 2000). Diversos estudos demonstraram a utilidade da técnica de PCR em tempo real como sendo sensível, específica e confiável na quantificação do DNA humano (ALONSO et al., 2003; ANDRÉASSON; GYLLENSTEN; ALLEN, 2002; GREEN et al., 2005).

No grupo de estudo das amostras relacionadas com a identificação de cadáveres, 2 das 20 amostras (10\%), apresentaram resultado nulo na quantificação de DNA humano e 7 (35\%) mostraram-se compatíveis com a classificação para amostras com baixo número de cópias (LCN - low copy number) (Tabela 11).

Nos casos de crimes sexuais, das 30 amostras analisadas, $1(3,3 \%)$ resultou nula na quantificação e 7 (23,3\%) apresentaram quantificações características de LCN (Tabela 12). Nas amostras de casos de crimes sexuais, o esperado seria que se a extração diferencial de DNA fosse totalmente bem sucedida, a quantificação de DNA masculino na Fração NãoEspermatozoide (FNE) fosse nula ou muito baixa, revelando que o DNA de origem masculina da mistura teria sido isolado na Fração Espermatozoide (FE). Nem sempre a extração 
diferencial é perfeita e isto pode ocasionar o aparecimento de mistura de perfis genéticos, tanto na FE como na FNE. Desta forma, nestes tipos de amostras faz-se necessária a observação cautelosa de todos os alelos amplificados, levando-se em consideração inclusive que eventuais stutters possam refletir alelos minoritários na mistura.

Entre as 30 amostras de vestígios biológicos de locais de crimes, 3 (10\%) não apresentaram valores de DNA humano e/ou DNA masculino na quantificação e 11 (36,6\%) puderam ser classificadas como LCN (Tabela 13).

Neste trabalho, tanto as amostras cuja quantificação resultou nula, quanto aquelas típicas LCN foram submetidas às reações de amplificação de DNA para os triplex NC01 e NC02, na expectativa de se observar os possíveis resultados, porém, respeitando-se o volume máximo estabelecido de amostra e duplicando-se o volume total de reação.

Quando da amplificação nos sistemas multiplex NC01 e NC02, as amostras dos casos de identificação de cadáveres apresentaram 10\% de ausência total de amplificação (2 em 20 06-Ossada de recém-nascido e 14-Osso úmero) e outros $10 \%$ de perfis alélicos parciais, compreendendo duas amostras (05-Osso fêmur e 13-Osso fêmur), que haviam sido classificadas como contendo um baixo número de cópias. Justamente estes casos corresponderam a um maior lapso temporal entre o óbito e a análise laboratorial, sendo que num deles (de perfil parcial - 05-Osso fêmur) a amostra óssea foi submetida às condições ambientais de uma fossa asséptica por aproximadamente 1798 dias. Entretanto, para 5 outras amostras que foram classificadas como LCN, foi possível obter o perfil alélico completo para os seis loci analisados (Tabela 14). Tal fato se deve possivelmente a dois fatores, sendo o primeiro a real sensibilidade dos sistemas $\mathrm{NC01}$ e $\mathrm{NC02}$, desenhados no formato de miniSTRs, que seriam ideais nos casos de amostras degradadas ou escassas e que realmente tiveram a capacidade de amplificação das amostras mais complexas e segundo, pelo fato do próprio processo de quantificação também ser sujeito a erros quando se trabalha com amostras extremamente reduzidas, com baixo número de cópias, em que simples repetições de pipetagem podem levar a alteração nos resultados (GILL, 2001; WHITAKER; COTTON; GILL, 2001).

Com relação às 5 amostras que foram submetidas a processo de carbonização (Tabela 1), não foram encontradas dificuldades no estabelecimento dos perfis alélicos completos para os sistemas analisados. A explicação para isto possivelmente está relacionada com o leve grau de carbonização destes materiais, ou seja, a carbonização externa do cadáver sem que houvesse degradação da totalidade dos tecidos e das moléculas de DNA neles contidas. 
Os resultados das amostras relacionadas com crimes sexuais demonstraram 2 ausências totais de amplificação (6,7\%), compatíveis com uma ausência de quantificação e uma classificação como LCN (21-Fragmento de lençol com supostas manchas de sêmen e 23B-Swab vaginal-FE). Perfis parciais nos miniSTRs foram observados em outras 2 amostras (6,7\% - 27-Calcinha com manchas de sêmen e 28-Espátula de madeira contendo secreção vaginal), também contendo baixo número de cópias de DNA e nas outras 5 na mesma situação classificatória foi possível obter o perfil de alelos em todas as regiões analisadas (Tabela 15), sugerindo as mesmas possibilidades acima expostas.

Os vestígios biológicos provenientes de locais de crimes apresentaram 6 (20\%) ausências totais de amplificação(37- Assento de veículo com supostas manchas de sangue, 38-A-Material subungueal, 40-Lâmina contendo secreção nasal, 42-Óculos de sol com eventuais células de descamação, 44-B-Tapete de borracha de veículo com supostas manchas de sangue e 49-A-Gaze contendo mancha de sangue-sítio 1), sendo 3 quantificações nulas e 3 LCN e 1 perfil parcial (3,3\%), também classificado como LCN (49-B-Gaze contendo mancha de sangue-sítio 2). Para os outros 7 exemplares cuja quantificação resultou muito baixa foi possível obter os alelos nos seis loci polimórficos pesquisados (Tabela 16), corroborando novamente as hipóteses de sensibilidade do sistema e resultados inadequados no processo de quantificação de amostras muito escassas.

Os perfis parciais obtidos, ou seja, a amplificação e obtenção de alelos para somente alguns dos loci polimórficos para uma dada amostra, não apresentaram diferença com relação aos sistemas NC01 e NC02, ou a qualquer microssatélite em específico, sugerindo ocorrerem pela deficiência na qualidade e/ou quantidade do DNA extraído e não devido a variações nas sensibilidades individuais dos sistemas.

As amostras sanguíneas analisadas nos três tipos de casos, seja sangue na forma líquida ou manchas sobre variados suportes, forneceram resultados bastante satisfatórios e sem necessidade de repetição. Tal constatação é importante em vista da maioria das amostrasreferência recebidas no laboratório serem desta fonte biológica.

Os estudos realizados das amostras individuais e agrupadas na forma de casos demonstraram a aplicabilidade destes microssatélites nas análises forenses de casos criminais, havendo consistência de dados e da presença de alelos de acordo com os históricos dos casos e a procedência das amostras, mesmo nas situações em que se detectou a presença de mistura de materiais genéticos. Salienta-se, desta maneira, a real utilidade e aplicabilidade deste estudo, visto que foi realizado com amostras de casos forenses reais, não simuladas. 
Entre os 53 casos analisados, foi observado um alelo não presente nos painéis na internet no STRBase (STRBASE, 2010) e também não descrito no estudo de Coble e Butler (2005). O alelo 8 no locus D2S441 foi compartilhado por pai e filho no Caso 24 deste estudo (Figura 24), tendo sido observado mesmo após repetição dos processos de amplificação e eletroforese capilar das amostras.

Dois casos estudados que haviam apresentado resultados sugestivos de mutações isoladas em outros microssatélites na rotina laboratorial tradicional tiveram resultados que reforçaram estas hipóteses (Figuras 25 e 26), evidenciandoa utilidade dos sistemas NC01 e NC02 quando se deseja ou se faz necessário o aumento do número de regiões do DNA analisadas num dado caso forense (GOODWIN et al., 2004; COBLE; BUTLER, 2005).

A comparação de genótipos realizada, desconsiderando-se as amostras de origens biológicas comuns, os perfis parciais e as misturas de DNA, apesar da reduzida amostragem para esta finalidade, sugeriu uma frequência genotípica menor do que $2 \%$ para o uso conjunto dos multiplex $\mathrm{NC01}$ e NC02, o que afirma o poder discriminatório do uso destes sistemas, o que é desejável na identificação humana por análise de DNA.

A simples obtenção de um mesmo perfil para um grupo de polimorfismos em duas amostras distintas não significa necessariamente que ambas possuam a mesma origem. Para que se interprete devidamente um fato como este faz-se necessário o conhecimento das frequências alélicas para cada marcador genético, na respectiva população de estudo. A coincidência na genotipagem, então, poderá e deverá ser expressa numericamente para que se possa avaliar a significância do ocorrido, mensurando-se assim a razão de verossimilhança entre as amostras (EVETT; WEIR, 1998).

Populações diferentes apresentam frequências alélicas diferentes para os microssatélites utilizados nos testes de identificação humana e estudos populacionais são essenciais para o tratamento estatístico devido nos casos de análise forense de DNA (TRACEY, 2001). Desta forma, para que os loci “non-CODIS" D1S1677, D2S441, D4S2364, D10S1248, D14S1434 e D22S1045 possam ser introduzidos na rotina forense com segurança e credibilidade devem ser realizados estudos da população brasileira, pesquisando-se um número representativo de indivíduos, sem vínculo de parentesco, publicando-se na literatura científica as frequências alélicas populacionais para cada marcador (LINCOLN; THOMSON, 1998). Tais publicações ainda não se encontram disponíveis para a população do Brasil, conforme revisão bibliográfica realizada, exceto pelo artigo em fase de publicação de Santos et al. (2010), que estudou somente os microssatélites D10S1248, D14S1434 e D22S1045, entre outros. 
Para que os dados gerados nos laboratórios que realizam análises de DNA sejam confiáveis e realmente admissíveis como provas nos tribunais, as instituições devem ter programas formais e detalhados para garantir e controlar a qualidade, monitorando o trabalho individual e do laboratório como um todo, aliado a programas de educação continuada e treinamentos contínuos de sua equipe. Além disso, é ideal que o laboratório participe, ou seja submetido a programas de controle de qualidade externos e auditorias periódicas para avaliação de sua adequação a um padrão mínimo necessário.

Entretanto, diferentemente do sistema anglo-americano, onde as regras de admissibilidade de provas são extremamente cautelosas e rígidas, a introdução das provas pautadas em exame de DNA no sistema legal brasileiro se deu de forma acrítica, tal qual se passa com as aquisições de produtos culturais estrangeiros em nossa sociedade. No afã da modernidade, importamos a técnica sem, contudo, importar as soluções propostas para sua adequação e, o que talvez seja pior, principalmente nos laboratórios públicos, sem as mínimas condições materiais para desenvolvê-la com excelência e sem o preparo técnico exigido para a implementação de uma técnica de tão grande complexidade (BONACCORSO, 2005).

A exigência deste controle de qualidade rigoroso não favorece a utilização de muitos processos do tipo "in-house" nos laboratórios forenses, não pela falta de capacidade de se realizar os procedimentos de verificação necessários, mas pelas dificuldades técnicas em se padronizar e validar cada lote de reagentes, em tempo hábil e para o volume de trabalho atribuído aos trabalhadores do setor. Desta forma, apesar do custo maior, há uma preferência pela aquisição e uso rotineiro de reagentes comerciais, cujos processos de controle de qualidade em larga escala disponibilizam um produto de fácil manuseio e conservação, com procedimentos padronizados ao longo de todo o processo e que resultam, consequentemente, em dados confiáveis e com maior possibilidade de reastreamento. A adoção destes reagentes comerciais, entretanto, não dispensa validações prévias realizadas individualmente por cada laboratório (DAB, 2000; SWGDAM, 2000).

Outro elemento desejável nas análises forenses de DNA, que garante uma maior segurança nas avaliações periciais, é a amplificação conjunta do locus da Amelogenina para cada uma das amostras pesquisadas, de forma que a classificação sexual possa ser realizada a cada processo de amplificação.

Durante o desenvolvimento do presente trabalho, mais especificamente no segundo semestre de 2009, foram lançados no mercado três kits comerciais para amplificação de microssatélites, sendo que três dos seis loci deste estudo (D2S441, D10S1248 e D22S1045) fazem parte do painel de alelos por eles analisados. Os kits PowerPlex® ESX 17, 
PowerPlex ${ }^{\circledR}$ ESI 17 (Promega Corporation, Madison/WI, EUA) e o AmpFlSTR® NGMTM PCR Amplification kit (Applied Biosystems, Foster City/CA, EUA) possuem os 5 novos loci recomendados pela ENFSI (Rede Européia dos Institutos de Ciências Forenses - European Network of Forensic Science Institutes) e pelo EDNAP (Grupo Europeu de Tipagem de DNA - European DNA Profiling Group), D1S1656, D2S441, D10S1248, D12S391 e D22S1045; além de outros 11 loci comumente utilizados pela comunidade europeia, D2S1338, D3S1358, D8S1179, D16S539, D18S51, D19S433, D21S11, FGA, TH01, vWA e Amelogenina.

A disponibilidade atual destes kits de reagentes no mercado nacional, a despeito de seu alto custo, favorece ainda mais o seu emprego, em detrimento das metodologias "in-house", como a aqui estudada. 
6 CONCLUSÃO 
Com base nos resultados e discussões apresentados neste trabalho, pode-se concluir que:

6.1 Os sistemas $\mathrm{NC01}$ e $\mathrm{NC} 02$, para a amplificação no formato multiplex dos microssatélites “non-CODIS” D1S1677, D2S441, D4S2364, D10S1248, D14S1434 e D22S1045, padronizados neste estudos mostraram-se sensíveis, robustos e úteis para o seu emprego em amostras destinadas à análise forense criminal de DNA;

6.2 A utilização de processo "in-house" em laboratório de análise forense de DNA mostrou-se trabalhosa e desvantajosa devido a maiores preocupações inerentes ao controle de qualidade, em comparação com o uso de reagentes comerciais previamente validados para esta finalidade;

6.3 Para que a análise dos loci "non-CODIS" seja introduzida na rotina laboratorial são necessários estudos populacionais e o estabelecimento de bancos de dados de frequências alélicas da população brasileira, ainda inexistentes.

A importância deste estudo torna-se evidente ao se considerar o número e a grande variedade de amostras forenses criminais reais analisadas, não simuladas, envolvendo diferentes metodologias de extração de DNA, o que demonstra a viabilidade de pesquisas na área forense e sua utilidade e aplicabilidade na prática da atividade pericial. 


\section{REFERÊNCIAS*}

ALONSO, A.; MARTIN, P.; ALBARRAN, C.; GARCIA, P.; PRIMORAC, D.; GARCIA, O.; FERNANDEZ DE SIMON, L.; GARCIA-HIRSCHFELD, J.; SANCHO, M; FERNANDEZPIQUERAS, J. Specific quantification of human genomes from low copy number DNA samples in forensic and ancient DNA studies. Croat. Med. J., v. 44, p. 273-280, 2003.

ANDRÉASSON, H.; GYLLENSTEN, U.; ALLEN, M. Real-time DNA quantification of nuclear and mitochondrial DNA in forensic analysis. BioTechniques, v. 33, p. 402-411, 2002.

BENnETT, P. Demystified...Microsatellites. J. Clin. Pathol.: Mol. Pathol., v. 53, p.177$183,2000$.

BONACCORSO, N. S. Aplicação do exame do DNA na elucidação de Crimes. 2005. $156 f$. Dissertação (Mestrado) - Faculdade de Direito, Universidade de São Paulo, São Paulo, 2005.

BONACCORSO, N. S.; PERIOLI, C. Centro de Custódia. In: CONGRESSO NACIONAL DE CRIMINALÍSTICA, 16., 2001, Florianópolis. Anais... Florianópolis: Associação Brasileira de Criminalística e Associação dos Peritos Oficiais de Santa Catarina, 2001.

BRASIL. Código de Processo Penal. Decreto-Lei n 3.684, de 3 de outubro de 1941.

BRETtell, T. A.; BUTleR, J. M.; AlMiRAll, J. R. Forensic science. Anal. Chem., v. 81, p. 4695-4711, 2009.

BUCKLETON, J.; TRIGGS, C. M.; WALSH, S. J. Forensic DNA Evidence Interpretation. Florida: CRC Press, 2005. 534 p.

BUTLER, J. M. Forensic DNA Typing - Biology \& Technology Behind STR Markers. 2nd ed. San Diego: Academic Press, 2005. 660 p.

BUTLER, J. M. Mini-Review - Short tandem repeat typing technologies used in human identity testing. BioTechniques, v. 43, n. 4, p. Sii-Sv, 2007. Supplement.

*De acordo com: ASSOCIAÇÃO BRASILEIRA DE NORMAS TÉCNICAS. NBR 6023:

Informação e documentação: referências: elaboração. Rio de Janeiro, 2002. 
BUTLER, J. M.; SHEN, Y.; McCORD, B. R. The development of reduced size STR amplicons as tools for analysis of degraded DNA. J. Forensic Sci., v. 48, n. 5, p. 1054-1064, 2003.

CHEMELlO, E. Química Virtual. mar. 2007. Disponível em: <http://www. quimica.net/emiliano/artigos/2007mar_forense4.pdf>. Acesso em: 08 jun. 2010.

CHUNG, D.; DRABEK, J.; OPEL, K.; BUTLER, J.; MCCORD, B. A study on the Effects of Degradation and Template Concentration on the Amplification Efficiency of the STR Miniplex Primer Sets. J. Forensic Sci., v. 49, n. 4, p. 733-740, 2004.

COBLE, M. D.; BUTLER, J. M. Characterization of New MiniSTR Loci to Aid Analysis of Degraded DNA. J. Forensic Sci., v. 50, n. 1, p. 43-53, 2005.

COBLE, M. D.; HILl, C. R.; VAllONE, P. M.; BUTLER, J. M. Characterization and performance of new MiniSTR loci for typing degraded samples. International Congress Series, v. 1288, p. 504-506, 2006.

CONSELHO NACIONAL DE PESQUISA - NRC. A tecnologia do DNA na ciência forense. Tradução F. A. M. Duarte et al. Ribeirão Preto: FUNPEC-RP, 1999. 202 p.

A Avaliação do DNA como prova forense. Tradução F. A. M. Duarte et al. Ribeirão Preto: FUNPEC-RP, 2001. 283 p.

DAB - DNA Advisory Board. Quality Assurance Standards for Forensic DNA Testing Laboratories - Federal Bureau of Investigation. Forensic Science Communications. 2000. Disponível em: < http://www.fbi.gov/about-us/lab/codis/qas_testlabs>. Acesso em: 08 jun. 2010.

DEL-CAMPO, E. R. A. Medicina Legal. 2. ed. São Paulo: Saraiva, 2006. cap. 3, p. 57-99.

DIXON, L. A.; DOBBINS, A. E.; PULKER, H. K.; BUTLER, J. M.; VALLONE, P. M.; COBLE, M. D.; PARSON, W.; BERGER, B. Analysis of artificially degraded DNA using STRs and SNPs - results of a collaborative European (EDNAP) exercise. Forensic Sci. Int., v. 164, p. 33-44, 2006.

EVETT, I. W.; WEIR, B. S. Interpreting DNA Evidence. Sunderland, Massachusetts: Sinauer Associates, Inc., 1998. 142 p. 
FBI - FEDERAL BUREAU OF INVESTIGATION. Handbook of Forensic Service - DNA Examinations - DNA general. U. S. Department of Justice. 2007. Disponível em: <http://www.fbi.gov/hq/lab/handbook/forensics.pdf>. Acesso em: 08 jun. 2010.

FORENSIC SEROLOGY. MegaLinks in Criminal Justice. Disponível em: <http://www.apsu.edu/oconnort/3210/3210lect06.htm>. Acesso em: 08 jun. 2010.

GENBANK, National Center for Biotechnology Information, Search/nucleotide/for/, Disponível em: <http://www.ncbi.nlm.nih.gov> . Acesso em: 08 jun. 2010.

GEP-ISFG - GRUPO ESPAÑOL Y PORTUGUÉS DE LA INTERNATIONAL SOCIETY OF FORENSIC GENETICS. Recomendaciones del Grupo Español y Portugués de la ISFG - International Society of Forensic Genetics - para la recogida y envío de muestras con fines de identificación genética. Madeira: ISFG, 2000.

GILL, P. Application of low copy number DNA profiling. Croat. Med. J., v. 42, p. 229-232, 2001.

GILL, P.; FEREDAY, L.; MORLING, N.; SCHNEIDER, P. M. The evolution of DNA databases - recommendations for new European STR loci. Forensic Sci. Int., v. 156, p. 242244, 2006.

GILL, P.; JEFFREYS, A. J.; WERRET, D. J. Forensic application of DNA "fingerprints". Nature, v. 318, p. 577-579, 1985.

GILL, P.; SPARKES, R. L.; BUCKLETON, J. S. Interpretation of simple mixtures when artifacts such as stutters are present-with special reference to multiplex STRs used by the Forensic Science Service. Forensic Sci. Int., v. 95, p. 213-224, 1998.

GILL, P.; WHITAKER, J.; FLAXMAN, C.; BROWN, N; BUCKLETON, J. An investigation of the rigor of interpretation rules for STRs derived from less than $100 \mathrm{pg}$ of DNA. Forensic Sci. Int., v. 112, p. 17-40, 2000.

GITAD - GRUPO IBEROAMERICANO DE TRABAJO EN ANÁLISIS DE DNA Recomendaciones del Grupo Iberoamericano de Trabajo en Análisis de DNA - GITAD para recogida de pruebas y muestreo de ADN. Granada: Academia Iberoamericana de Criminalística y Estudios Forenses (AICEF), 2002. 
GOLDIM, J. R.; MATTE, U. Bancos de DNA. Considerações éticas sobre o armazenamento de material genético. 1999. Disponível em: <http://www.ufrgs.br/bioetica/bancodn.htm>. Acesso em: 08 jun. 2010.

GONZALEZ, C. L. A Criminalística - Aspectos Históricos, Doutrinários, Jurídicos e Técnicos. A Perícia nos Locais de Crime. 2004. 47 f. Dissertação (Comissão de seleção de Professor Temporário da Unidade Docente II). Academia de Polícia "Dr. Coriolano Nogueira Cobra”, São Paulo, 2004.

GOODWIN, W.; BALLARD, D.; SIMPSON, K.; THACKER C.; SYNDERCOMBE COURT D.; GOW, J. Case study: paternity testing-when 21 loci are not enough. In: DOUTREMEPUICH, C.; MORLING, N. (Ed.). Progress in forensic genetics 10. Amsterdam, The Netherlands: International Congress Series, 2004. v. 1261, p. 460-462.

GREEN, R. L.; ROINESTAD, I. C.; BOLAND, C.; HENNESSY, L. K. Developmental validation of the quantifi ler real-time PCR kits for the quantifi cation of human nuclear DNA samples. J. Forensic Sci., v. 50, p. 809-825, 2005.

GRIFFITHS, A. J. F. et al. Modern Genetic Analysis. New York: W. H. Freeman and Company, 1999. 675 p.

HANSON, E. K.; BALLANTYNE, J. A highly discriminating 21 locus 'megaplex' system designed to augment the minimal haplotype loci for forensic casework. J. Forensic Sci., v. 49, p. 40-51, 2004.

HILL, C. R.; BUTLER, J. M.; VALlONE, P. M. A 26plex Autosomal STR Assay do Aid Human Identity Testing. J. Forensic Sci., v. 54, n. 5, p.1008-1015, 2009.

HILL, C. R.; KLINE, M. C.; COBLE, M. D.; BUTLER, J. M. Characterization of 26 miniSTR loci for improved analysis of degraded DNA samples. J. Forensic Sci., v. 53, n. 1, p. 73-80, 2008.

INTERPOL - INTERNATIONAL CRIMINAL POLICE ORGANIZATION. INTERPOL Handbook on DNA data exchange and practice. (manual online). 2001. Disponível em: $\langle$ http://www.interpol.int/Public/Forensic/dna/HandbookPublic.pdf $>$. Acesso em: 08 jun. 2010.

ISCAN, M. Y. Global forensic anthropology in the 21st century. Forensic Sci. Int., v. 117, p. $1-6,2001$. 
JEFFREYS, A. J.; WILSON, V.; THEIN, S. L. Hipervariable "minisatellite" regions in human DNA. Nature, v. 314, p. 67-73, 1985a.

JEFFREYS, A. J.; WILSON, V.; THEIN, S. L. Individual-specific "fingerprints" of human DNA. Nature, v. 316, p. 75-79, 1985 b.

JOBIM, L. F.; JOBIM M. R.; BRENNER, C. Identificação humana pelo DNA: investigação de paternidade e análise de casos forenses. In: TOCHETTO, D. (Coord.). Identificação Humana. Porto Alegre: Sagra-Luzzatto, 1999. parte IV.

JOBLING, M. A.; GILL, P. Encoded evidence: DNA in forensic analysis. Nature Reviews Genetics, v. 5, p. 739-51, 2004.

KLINTSCHAR, M.; IMMEL, U.; STILLER, D.; KLEIBER, M. HumTH01 and blood pressure. An obstacle for forensic application? In: DOUTREMEPUICH, C.; MORLING, N. (Ed.). Progress in Forensic Genetics 10. Amsterdam, The Netherlands: International Congress Series, 2004. v. 1261, p. 589-591.

LADD, C.; LEE, H. C.; YANG, N.; BIEBER, F. R. Interpretation of complex forensic DNA mixtures. Croat. Med. J., v. 42, n. 3, p. 244-246, 2001.

LINCOLN, P. J.; THOMSON, J. Methods in molecular biology - Forensic DNA profiling protocols. Totowa, NJ: Humana Press, 1998.

LOPES, V.; ANDRADE, L.; CARVALHO, M.; SERRA, A.; BALSA, F.; BENTO, A. M.; BATISTA, L.; OLIVEIRA, C.; CORTE-REAL, F.; ANJOS, M. J. Mini-STRs: A powerful tool to identify genetic profiles in samples with small amounts of DNA. Forensic Sci. Int.: Genetics Supplement Series, v. 2, p. 121-122, 2009.

LYGO, J. E.; JOHNSON, P. E.; HOLAWAY, D. J.; WOODROFFE, S.; WHITAKER, J. P.; CLAYTON, T. M. The validation of short tandem repeat (STR) loci for use in forensic casework. Int. J. Legal Med., v. 107, p. 77-89, 1994.

MANIATIS, T.; SAMBROOK, J.; FRITSCH, E. F. Molecular Cloning: A Laboratory Manual. 2nd ed. New York: Cold Spring Harbor Laboratory Press, 1996.

MORETTI, T.; BAUMSTARK, A.; DEFENBAUGH, D.; KEYS, K.; SMERICK, J.; BUDOWLE, B. Validation of Short Tandem Repeats (STRs) for Forensic Usage: Performance Testing of Fluorescent Multiplex STR Systems and Analysis of Authentic and Simulated Forensic Samples. J. Forensic Sci., v. 46, p. 647-660, 2001. 
MOURA NETO, R. S. A investigação de Crimes Sexuais através do Estudo do DNA. Rev. Panorama da Justiça, n. 10, p. 44-54, 1998.

NIJ - NATIONAL INSTITUTE OF JUSTICE. The Future of Forensic DNA Testing: Predictions of the Research and Development Working Group. U. S. Department of Justice. 2000. Disponível em: 〈http://www.ncjrs.gov/pdffiles1/nij/183697.pdf>. Acesso em: 08 jun. 2010.

OPEL, K. L.; CHUNG, D. T.; DRÁBEK, J.; BUTLER, J. M.; McCORD, B. R. Developmental Validation of Reduced-Size STR Miniplex Primer Sets. J. Forensic Sci., v. 52, n. 6, p. 1263-1271, 2007.

PARSONS, T. J.; HUEL, R.; DAVOREN, J.; KATZMARZYK, C.; MILOS, A.; SELMANOVIC, A.; SMAJLOVIC, L.; COBLE, M. D.; RIZVIC, A. Application of novel "mini-amplicon" STR multiplexes to high volume casework on degraded skeletal remains. Forensic Sci. Int.: Genetics v. 1, p. 175-179, 2007.

PENA, S. D. J. O DNA como (única) testemunha em determinação de paternidade. Bioética. v. 5, p. 231-241, 1997.

PRIMORAC, D.; SCHANFIELD, M. S.; PRIMORAC, D. Application of forensic DNA testing in the legal system. Croat. Med. J., v. 41, n. 1, p. 32-46, 2000.

QIAGEN. QIAGEN Multiplex PCR Handbook. Disponível em: <www.qiagen.com/ literature/render.aspx?id=372>. Acesso em: 01 jun. 2010.

QUANTIFILER DUO. Quantifiler DUO DNA Quantification Kit User's Manual. Disponível em: <www.appliedbiosystems.com.br/site/material/5q7aqqbm.pdf>. Acesso em: 07 jun. 2010.

RAPLEY, R.; WHITEHOUSE, D. Molecular Forensics. England: Wiley, 2007. 244 p.

RUDIN, N.; INMAN, K. An introduction to forensic DNA analysis. 2nd ed. Florida: CRC Press, 2002. 292 p.

SAIKI, R. K.; GELFAND, D. H.; STOFFEL, S.; SCHARF, S. J.; HIGUCHI, R.; HORN, G. T.; MULLIS, K. B; ERLICH, H. A. Primer-directed enzymatic amplification of DNA with a thermostable DNA polymerase. Science. v. 239, n. 4839, p. 487-491, 1988. 
SANTOS, L. L.; DE ASSIS, J. B.; REIS, A. H.; SCLIAR, M.D.; CARVALHO, M. R.; VAINTRAUB, M. T.; VAINTRAUB, P. Allele distribution of six STR/miniSTR loci (CD4, FABP2, D12S391, D14S1434, D22S1045 and D10S1248) for forensic purposes in Southeastern Brazil. Ann. Hum. Biol., 2010. In press.

SÃO PAULO (Estado). Resolução SSP 382 de 1 de setembro de 1999. Dispõe sobre diretrizes a serem seguidas no atendimento de locais de crime Diário Oficial do Estado. Poder Executivo, São Paulo, 1 set. 1999a. Seção I.

Resolução SSP 194 de 2 de junho de 1999. Estabelece normas para coleta e exame de materiais biológicos para identificação humana. Diário Oficial do Estado. Poder Executivo, São Paulo, 2 jun. 1999b. Seção I, p. 3.

SHARMA, P.; HINGORANI, A.; JIA, H.; ASHBY, M.; HOPPER, R.; CLAYTON, D.; BROWN, M. J. Positive association of tyrosine hydroxylase microsatellite marker to essential hypertension. Hypertension, v. 32, n. 4, p. 676-682, 1998.

STRACHAN, T.; READ, A. Genética molecular humana. 2. ed. Porto Alegre: Artmed, 2002. $578 \mathrm{p}$.

STRBASE. Short Tandem Repeat DNA Internet DataBase. Disponível em: <http://www. cstl.nist.gov/strbase/> Acesso em: 07 jul. 2010.

STUMVOLL, P. V.; QUINTELA, V. M. D. O. Criminalística. In: TOCHETTO, D. (Coord.). Tratado de Perícias Criminalísticas. Porto Alegre: Sagra-Luzzato, 1995. p. 5-38.

SWGDAM - Scientific Working Group on DNA Analysis Methods. Short Tandem Repeat (STR) Interpretation Guidelines. 2000. Disponível em: <http://www.fbi.gov/hq/lab/ fsc/backissu/july2000/strig.htm>. Acesso em: 08 jun. 2010.

TOBE S. S.; WATSON, N.; DAÉID N. N. Evaluation of Six Presumptive Tests for Blood, Their Specificity, Sensitivity, and Effect on High Molecular-Weight DNA. J. Forensic Sci., v. 52, p. 102-109, 2007.

TRACEY, M. Short tandem repeat based identification of individuals and parents. Croat Med J., v. 42, n. 3, p. 233-238, 2001. 
VALLONE, P. M.; HILL, C. R.; LEWIS, K. E.; DIEGOLI, T. M.; COBLE, M. D.; BUTLER, J. M. Uses of the NIST 26plex STR Assay for Human Identity Testing. In: INTERNATIONAL SYMPOSIUM ON HUMAN IDENTIFICATION, 18., 2007. Poster... Hollywood/CA, EUA, 2007. Disponível em: <http://www.cstl.nist.gov/strbase/pub_pres/ Vallone-26plex-ISFG2009 poster.pdf >. Acesso em: 07 jun. 2010.

WALKER, M. R.; RAPLEY, R. Guia de rotas na tecnologia do gene. São Paulo: Atheneu, 1999.

WALSH, P. S.; METZGER, D. A.; HIGUCHI, R. Chelex ${ }^{\circledR} 100$ as a Medium for Simple Extraction of DNA for PCR-Based Typing from Forensic Material. BioTechniques, v. 10, n. 4, p. 506-513, 1991.

WEEDN, V. W; SWARNEN, S. L. Exames forenses de identificação por análises do DNA. In: HENRY, J. B. et al. Diagnósticos clínicos e tratamento por métodos laboratoriais. 19. ed. São Paulo: Manole, 1998. cap. 63, p. 1427-1438.

WEIR, B. S.; TRIGGS, C. M.; STARLING, L.; STOWELL, L. I.; WALSH, K. A. J.; BUCKLETON, J. S. Interpreting DNA mixtures. J. Forensic Sci., v. 42, p. 213-222, 1997.

WHITAKER, J. P.; COTTON, E. A.; GILL, P. A comparison of the characteristics of profiles produced with the AMPFISTR®SGM PlusTM multiplex system for both standard and low copy number (LCN) STR DNA analysis. Forensic Sci. Int., v. 123, p. 215-223, 2001.

WIEGAND, P.; KLEIBER, M. Less is more - length reduction of STR amplicons using redesigned primers. Int. J. Legal Med., v. 114, p. 285-287, 2001.

WIKIPEDIA THE FREE ENCYCLOPEDIA. Chain of custody. Disponível em: <http://en.wikipedia.org/wiki/Chain_of_custody>. Acesso em: 08 jun. 2010.

ZARZUELA, J. L.; MATUNAGA, M.; THOMAZ, P. L. Laudo pericial: aspectos técnicos e jurídicos. São Paulo: Ed. RT, 2000. 371 p. 


\section{ANEXO A}

\section{Resolução SSP-194, de 2-6-99}

\section{identificação humana.}

Estabelece normas para coleta e exame de materiais biológicos para

O Secretário da Segurança Pública, nos termos do Decreto 42.815, de 19, publicado a 20-198, Considerando:

a) a necessidade de normalizar os serviços periciais relativos à coleta de materiais biológicos para exames de identificação humana, tanto nos locais de crime quanto na pessoa humana, viva ou morta;

b) que os procedimentos a serem seguidos pelos órgãos policiais e periciais oficiais devem estar em consonância com os ditames da legislação em vigor, e

c) que é imprescindível à correta preservação das amostras para não haver contaminações ou outros prejuízos,

RESOLVE:

\section{I - DISPOSIÇÕES GERAIS}

Artigo $1^{\circ}$ - A coleta de material biológico e os procedimentos preliminares para exame de identificação humana pela análise do DNA ou equivalente seguirão as normas e procedimentos dispostos no ANEXO desta Resolução.

Parágrafo Único - Por exame de identificação humana entende-se todo e qualquer procedimento experimental biológico ou bioquímico tendente a estabelecer a identidade da pessoa humana, bem como sua inclusão ou exclusão em análises de confronto entre o material coletado e aquele por ela, ou seus parentes, fornecido.

Artigo $2^{\mathbf{0}}$ - As análises de DNA serão realizadas exclusivamente em materiais relacionados, direta ou indiretamente, a ilícitos penais, salvo determinação legal em contrário, e desde que estejam acompanhadas dos respectivos padrões biológicos para confronto.

Artigo $3^{\mathbf{0}}$ - As coletas em locais de crimes, mediatos ou imediatos, ou ainda, idôneos ou inidôneos, para os exames definidos no artigo $1^{\circ}$, serão procedidas, exclusivamente, por Peritos Criminais, ressalvado o disposto no artigo $5^{\circ}$.

$\$ \mathbf{1}^{\mathbf{0}}$ - Ficam impedidos de proceder às análises de laboratório os Peritos que efetuaram a coleta de material em local.

$\$ \mathbf{2}^{\mathbf{0}}$ - Os Peritos Criminais que coletaram as amostras elaborarão o respectivo laudo pericial, do qual fará parte o relatório do exame de identificação requisitado.

Artigo $4^{\mathbf{0}}$ - Somente serão recebidas para análises biológicas de identificação humana as amostras de acordo com as normas aqui estabelecidas.

$\S \mathbf{1}^{\mathbf{0}}$ - Não havendo condições imediatas de confronto pela ausência de material padrão para comparação, mas sendo o caso de interesse judiciário para futura identificação, as amostras que, após análise prévia por Perito especialista em identificação humana, revelarem-se adequadas, serão devidamente selecionadas, etiquetadas e preservadas, pelo prazo de 90 (noventa) dias, para futuro exame.

$\$ \mathbf{2}^{\mathbf{0}}$ - O interesse judiciário a que alude o parágrafo anterior deverá estar devidamente expresso e justificado na requisição de exame pericial. 
$\S 3^{\mathbf{o}}$ - Decorrido o prazo aludido no parágrafo anterior, e não havendo nova manifestação do requisitante, o material será descartado.

$\S \mathbf{4}^{\mathbf{0}}$ - Havendo possibilidade tecnológica, as amostras a serem preservadas poderão ser analisadas, sendo o resultado desta análise registrado em computador para futuro confronto.

Artigo $5^{\circ}$ - É competência exclusiva de Médico Legista a coleta de material biológico para fins de identificação de pessoas vivas ou cadáveres, nos termos desta Resolução.

Parágrafo Único - A coleta de material biológico em pessoas vivas será feita somente em locais apropriados e com o expresso consentimento destas.

Artigo $6^{\mathbf{0}}$ - Em toda coleta de material biológico de pessoas vivas, suspeitas, vítimas ou parentes consangüíneos de primeiro grau e de envolvidos em crimes, será lavrado um termo de coleta, contendo:

a) nome do doador;

b) número da Cédula de Identidade e respectivo órgão expedidor;

c) somente no caso de coleta de amostra de sangue:

1 ) declaração de estar doando voluntariamente 02 (duas) amostras de sangue periférico, a serem colhidas por punção venosa;

2) declaração de não haver recebido transfusão sangüínea nos últimos 90 (noventa) dias e não ter sido submetido a transplante de medula óssea;

d) número do Boletim de Ocorrência Policial, Inquérito ou Processo a que se refere o caso, bem como da Autoridade requisitante;

e) local, data e horário da coleta;

f) assinatura do doador, do Médico Legista e de 02 (duas) testemunhas. No caso do doador ser analfabeto ou incapacitado, além de sua impressão digital, será exigida a assinatura de uma terceira testemunha a rogo;

g) declaração do doador de que está fornecendo o material de livre e espontânea vontade;

h) declaração do órgão coletor de que a coleta será utilizada exclusivamente para exames forenses relacionados com a ocorrência em tela, visando preservar seus direitos de pessoa humana e evitar imputações criminosas indevidas.

\section{II - DISPOSIÇÕES TRANSITÓRIAS}

Artigo $7^{0}$ - O Instituto de Criminalística, através do Centro de Exames, Análises e Pesquisas, planejará e providenciará o necessário treinamento para as equipes periciais designadas estarem aptas à coleta de amostras, a iniciar-se no prazo máximo de 30 (trinta) dias da data de publicação desta Resolução.

Parágrafo Único - Até que a Superintendência da Polícia Técnico-Científica esteja estruturada para o treinamento aludido no "caput", a Academia de Polícia Civil fornecerá o necessário aporte didático e administrativo.

Artigo $8^{\circ}$ - Esta Resolução entrará em vigor na data de sua publicação, revogando-se as disposições em contrário.

\section{ANEXO \\ DISPOSIÇÕES PRELIMINARES}

I - Durante qualquer coleta de material biológico é imprescindível a utilização de luvas descartáveis, para que se evite contaminação exógena.

II - Todos os instrumentos e materiais utilizados na coleta deverão ser estéreis. 
III - Deverão ser evitadas coletas de amostras contaminadas por terra, vegetais e outros elementos orgânicos.

IV - Cada vestígio eleito para coleta deverá ser fotografado, ter sua origem descrita em relatório individual de identificação, indicando a data e a natureza da ocorrência; o local, a forma e as condições da coleta; o horário em que foi coletado, consignando-se, quando possível, o tempo aproximado após o crime; bem como a forma utilizada para acondicionamento e preservação.

V - Qualquer material que se destine à análise forense de DNA deverá, desde sua coleta até seu encaminhamento final, ser acondicionado isoladamente e devidamente identificado, através de relatório preceituado no item anterior.

VI - Todo material úmido coletado deverá permanecer em embalagem plástica pelo tempo máximo de duas horas.

VII - Para que se evite a degradação e a contaminação por microrganismos, o material a ser analisado, quando úmido, deverá ser necessariamente seco antes de seu acondicionamento final.

\section{DA COLETA, ACONDICIONAMENTO, PRESERVAÇÃO E ENCAMINHAMENTO DE MATERIAL BIOLÓGICO PARA ANÁLISE BIOLÓGICA DE IDENTIFICAÇÃO}

\section{A) Amostras relacionadas a locais e instrumentos de crime}

\section{Fluidos líquidos (sangue, esperma e saliva)}

VIII - Os fluidos líquidos deverão ser colhidos através de dispositivos próprios para coleta deste tipo de material, composto por haste longa, flexível, com ponta de algodão (denominados $s w a b)$ ou gaze. Deverão secar à temperatura ambiente em local ventilado e abrigado da luz solar, acondicionados isoladamente em envelope de papel escuro ou na própria embalagem do $s w a b$, e armazenados preferencialmente em congelador a vinte graus Celsius negativos $\left(-20^{\circ} \mathrm{C}\right)$ ou, na impossibilidade, em geladeira, a quatro graus Celsius $\left(4^{\circ} \mathrm{C}\right)$.

\section{Demais fluidos líquidos (urina e outros).}

IX - Deverão ser colhidos com seringa ou pipeta plástica, transferidos para frasco próprio e armazenados sob refrigeração.

\section{Fluidos líquidos contidos em vestes ou em objetos}

$\mathrm{X}$ - As vestes ou os objetos umedecidos por manchas de fluídos biológicos deverão ser secos à temperatura ambiente, em local ventilado e protegido da luz solar, acondicionados em envelope de papel escuro ou caixa de papelão própria e armazenados sob refrigeração.

\section{Fluidos secos (sangue, esperma, urina, saliva e outros)}

XI - Vestígios de material biológico seco, contidos em pequenas áreas de vestes ou em pequenos objetos, deverão, quando possível, ser enviados em sua totalidade para análise.

XII - No caso destes vestígios serem encontrados em grandes objetos ou superfícies não absorventes como metais, paredes e móveis, a mancha de material biológico deverá ser retirada com o auxílio de uma lâmina de bisturi ou espátula própria para raspagem ou, ainda, com o uso de $s w a b$ umedecido em água destilada estéril e, neste último caso, proceder-se-á necessariamente, após a coleta, a secagem do material.

XIII - Em caso dos vestígios estarem contidos em objetos que possam ser cortados como carpetes, tapetes e madeira, o fragmento com a mancha deverá ser recortado com o auxílio de tesoura ou bisturi. 
XIV - Todo vestígio de material biológico seco, independentemente do método utilizado para sua coleta, deverá ser acondicionado isoladamente em envelope de papel escuro ou caixa de papelão própria e armazenado sob refrigeração.

\section{Tecidos, órgãos, dentes e ossos novos ou antigos}

XV - Deverão ser retirados fragmentos ou partes inteiras de tecidos, órgãos, dentes e ossos com a utilização de pinças, evitando-se mistura de materiais que deverão ser acondicionados isoladamente em frasco próprio ou em envelope de papel ou caixa de papelão, de acordo com o tipo de material e armazenados em congelador $\left(-20^{\circ} \mathrm{C}\right)$.

XVI - Como regra geral de preservação do material biológico a ser analisado, não deve, em hipótese alguma, ser utilizada água oxigenada, substâncias cáusticas (como soda) ou clarificantes (como água sanitária), para limpeza de ossos ou dentes.

\section{Pêlos e cabelos}

XVII - Sejam as amostras individuais ou em tufos, se misturadas com fluidos e tecidos corpóreos, os pêlos ou cabelos, com bulbos, deverão ser separados dos componentes da mistura que os contém.

XVIII - Devem ser evitadas amostras desprovidas de bulbos (raízes), cujo exame dependa da extração diferenciada de DNA (DNA-mitocondrial).

XIX - No caso de amostras úmidas, o material deverá ser seco à temperatura ambiente, ao abrigo da luz solar e em local ventilado e, em qualquer tipo de amostra, cada grupo de pêlos ou cabelos deverá ser acondicionado separadamente em envelope de papel escuro e acondicionado sob refrigeração.

\section{B) Amostras post-mortem (em casos de crimes sexuais)}

XX - As amostras da vítima deverão ser sempre coletadas em duplicata.

XXI - Nos crimes sexuais, além da coleta de sangue para identificação da vítima, como preceituada no item XXVII a seguir, deverão ser colhidas, com a utilização de $s w a b$, amostras da vagina, ânus, boca e possíveis vestígios contidos sob as unhas.

XXII - Sêmen contido na face, ou outras áreas do corpo, também pode ser com swab umedecido em água destilada estéril. Nestes casos, uma outra área adjacente, livre de sêmen, deverá ser também esfregada com swab para a obtenção de um controle.

XXIII - Após secagem em temperatura ambiente, ao abrigo da luz solar e em local ventilado, cada $s w a b$ deverá ser isoladamente acondicionado em sua própria embalagem e armazenado sob refrigeração.

\section{Amostras-referência (de origem conhecida)}

\section{Em vivos:}

XXIV - Precedendo-se à coleta de material, o suspeito ou familiar de vítima a ser identificada deverá fornecer por escrito seu consentimento de doação, lavrado em um "Termo de Coleta de Material Biológico" que seguirá junto às amostras para a aceitação do material a ser analisado.

XXV - Aproximadamente 5,0 mL de sangue periférico deverão ser colhidos em duplicata, através de punção venosa, com seringa hipodérmica descartável e transferidos para tubos plásticos com EDTA, devidamente identificados e armazenados em congelador $\left(-20^{\circ} \mathrm{C}\right)$. 


\section{Em cadáveres:}

XXVI - Amostras sangüíneas colhidas post-mortem podem sofrer problemas de contaminação e degradação do material para análise. Assim sendo, recomenda-se, quando possível, a retirada de sangue por punção cardíaca ou diretamente da cavidade cardíaca ou, ainda, de vaso de grosso calibre.

XXVII - No caso de cadáveres carbonizados, em decomposição ou decompostos, poderão ser retirados como amostras, conforme o caso, fragmentos de fígado, músculos, tufos de fíos de cabelos com bulbos, coágulos de sangue contidos nas cavidades e nos órgãos, dentes e ossos, preferencialmente como crista ilíaca, fêmur ou costela.

XXVIII - Cada amostra deverá ser colhida isoladamente e, de acordo com o seu tipo, preservada e acondicionada conforme as normas aqui dispostas para cada tipo específico de material e armazenadas em congelador $\left(-20^{\circ} \mathrm{C}\right)$. 


\title{
ANEXO B - Parecer da Comissão de Ética
}

\author{
SECRETARIA DA SEGURANÇA PÚBLICA \\ SUPERINTENDÊNCIA DA POLÍCIA TÉCNICO-CIENTÍFICA \\ INSTITUTO DE CRIMINALÍSTICA \\ "Perito Criminal Dr.Octávio Eduardo de Brito Alvarenga" \\ CENTRO DE EXAMES, ANÁLISES E PESQUISAS - CEAP \\ NÚCLEO DE BIOLOGIA E BIOQUÍMICA - LABORATÓRIO DE DNA
}

São Paulo, 20 de março de 2009.

Atesto para os devidos fins que o Núcleo de Biologia e Bioquímica do Instituto de Criminalística do Estado de São Paulo esteve de ciente e de acordo com o uso das amostras questionadas referentes aos casos recebidos em 2009 pela perita criminal Ana Claudia Pacheco, nas pesquisas do projeto entitulado "Emprego de miniSTRs "non-CODIS" em amostras biológicas de DNA forense", tendo como responsáveis o orientador Prof. Dr. Durvanei Augusto Maria e a própria mestranda Ana Claudia Pacheco.

Informo ainda que as amostras de indivíduos vivos foram fornecidas de espontânea vontade, com assinatura de Termo de Consentimento e comprometimento de Sigilo de sua identidade em todas as fases da pesquisa.

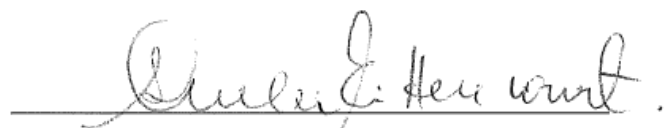

Dra. Eloísa A. Auler Bittencourt Diretora do Núcleo de Biologia e Bioquímica do Instituto de Criminalística do Estado de São Paulo 


\author{
ANEXO C \\ SECRETARIA DE SEGURANÇA PÚBLICA \\ SUPERINTENDÊNCIA DA POLÍCIA TÉCNICO-CIENTÍFICA
}

TERMO DE CONSENTIMENTO LIVRE E ESCLARECIDO

PARA COLETA DE MATERIAL BIOLÓGICO

Termo N. ${ }^{\circ}$

LACRE N.

B.O.N. ${ }^{\circ}$

I.P. N. ${ }^{\circ}$ Proc.

Local da Coleta

D.P. Data Órgão Requisitante

Requisitante

Responsável pela coleta

R.G.

Equipe

Pelo presente instrumento eu, , natural de

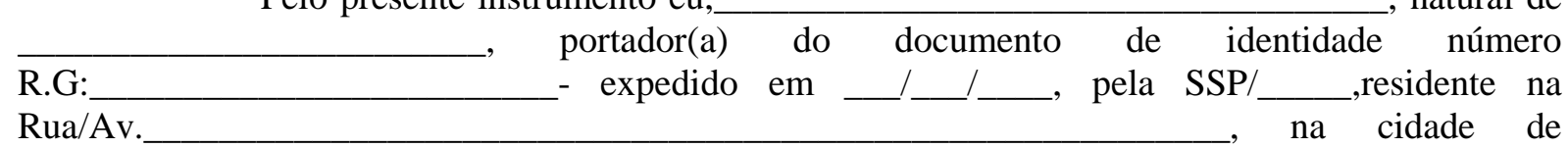
, autorizo que seja coletado meu material biológico (especificar) para ser submetido a exame de identificação genética (exame de DNA), estando ciente de que tal material será utilizado exclusivamente para efeitos de investigação científica forense relacionada com a ocorrência que originou esta solicitação, e, em caso de sua autorização poderá também ser utilizada em banco de dados genéticos e trabalhos científicos que visem caracterizar a população do Estado, como amostra anônima, tendo como objetivo precípuo a preservação de seus Direitos ou, se for o caso de seu parente. Declaro, ainda, não possuir irmã(o) gêmea (o) univitelínico (gêmeo idêntico).

(assinatura, nome completo e/ou R.G do Responsável)

Qual o grau de parentesco ou qual o envolvimento (Vítima/Indiciado/Acusado) na ocorrência?

E, por estar ciente e de acordo, assina o presente termo na presença da Autoridade Policial, Perito Criminal ou Médico Legista e das testemunhas abaixo, que a tudo que lhes foi permitido, presenciaram.

(assinatura do doador)

(assinatura do responsável pela coleta)

Test. Ass.:

(nome e R.G.)

Test. Ass.:

(nome e R.G.) 


\section{APÊNDICE A - Protocolos de Extração de DNA}

\section{1 - Extração de DNA de sangue total in natura e bem conservado}

\section{EXTRAÇÃO DE DNA COM CHELEX ${ }^{1}$}

1. Preparar a resina Chelex $5 \%$ (pesar $5 \mathrm{~g}$ e completar até $100 \mathrm{~mL}$ com água ultrapura);

2. Aliquotar $3 \mu \mathrm{L}$ de sangue total, ou $10 \mu \mathrm{L}$ de sangue de cadáver, ou um pedaço de tecido ou algodão com manchas hematóides com aproximadamente $0,5 \mathrm{~cm}^{2}$ em microtubo estéril identificado;

3. Adicionar $1 \mathrm{~mL}$ de água ultrapura;

4. Incubar a temperatura ambiente por 10 minutos (agitar a cada 2 minutos);

5. Centrifugar por $3 \mathrm{~min}$ a $14.000 \mathrm{rpm}$;

6. Descartar o sobrenadante deixando cerca de $30 \mu \mathrm{L}$ no tubo;

7. Adicionar $170 \mu \mathrm{L}$ de Chelex $5 \%$ (agitando sempre para que a resina esteja ressuspendida;

8. Agitar o tubo em alta rotação no vortex por 5-10 segundos;

9. Incubar em banho térmico a $56^{\circ} \mathrm{C}$ por 20 minutos;

10. Agitar o tubo em alta rotação no vortex por 5-10 segundos;

11. Incubar em banho térmico a $100^{\circ} \mathrm{C}$ por 8 minutos;

12. Agitar o tubo em alta rotação no vortex por 5-10 segundos;

13. Centrifugar por 3 min a $14.000 \mathrm{rpm}$;

14. DNA extraído;

15. Antes de amplificar, centrifugar a amostra por 3 minutos a $14.000 \mathrm{rpm}$;

16. Realizar a etapa de amplificação com $1 \mu \mathrm{L}$ do sobrenadante;

17. Conservar o DNA entre $0^{\circ}$ e $-20^{\circ} \mathrm{C}$.

2 - Extração de DNA de vísceras (eventualmente ossos e dentes em bom estado de conservação) ou para manchas de sangue ou sangue total in natura em péssimo estado de conservação

\section{EXTRAÇÃO DE DNA COM FENOL-CLOROFÓRMIO ${ }^{2}$}

1. Pipetar $50 \mu \mathrm{L}$ de sangue in natura ou de medula óssea, ou $0,5 \mathrm{~cm}^{2}$ de víscera ou mancha de sangue em microtubo de 1,5 mL;

2. Acrescentar $10 \mu \mathrm{L}$ de proteinase $\mathrm{K}(20 \mathrm{mg} / \mathrm{mL})$ e $300 \mu \mathrm{L}$ de "tampão de extração" (Tris$\mathrm{HCl} 10 \mathrm{mM}, \mathrm{NaCl} 100 \mathrm{mM}$, EDTA $10 \mathrm{mM}, 2 \%$ SDS, pH 8,0) e agitar suavemente no vortex por $10 \mathrm{~s}$;

3. Colocar em banho-maria a $56^{\circ} \mathrm{C}$ por:

a) 2 horas, se a amostra for sangue, ou víscera ou mancha de sangue;

b) overnight (18 a 24 h), se o material for medula óssea;

4. Para medula óssea, após o banho-maria overnight, acrescentar mais $10 \mu \mathrm{L}$ de proteinase $\mathrm{K}$ e incubar mais $1 \mathrm{~h}$ a $56^{\circ} \mathrm{C}$;

5. Acrescentar às amostras, $300 \mu \mathrm{L}$ da mistura fenol, clorofórmio, álcool isoamílico, na proporção 25:24:1 e, em seguida, agitar suavemente no vortex até formar uma mistura homogênea;

\footnotetext{
${ }^{1}$ Modificado a partir de: WALSH, P.S.; METZGER, D.A.; HIGUCHI, R. Chelex ${ }^{\circledR} 100$ as a Medium for Simple Extraction of DNA for PCR-Based Typing from Forensic Material. BioTechniques, v. 10, n. 4, p. 506-513, 1991.

${ }^{2}$ Modificado a partir de: MANIATIS, T.; SAMBROOK, J.; FRITSCH, E. F. Molecular Cloning: A Laboratory Manual. 2nd ed. New York: Cold Spring Harbor Laboratory Press, 1996.
} 
6. Centrifugar a $10.000 \mathrm{rpm}$ de 1 a 2 min;

7. Separar o sobrenadante (fase aquosa) com uma pipeta (cuidando sempre para não puxar a interfase) e transferi-lo para outro tubo de $1,5 \mathrm{~mL}$,

8. Se o sobrenadante não estiver limpo, repetir a operação por uma ou duas vezes, voltando ao item 5;

9. Acrescentar ao sobrenadante (fase aquosa) $200 \mu \mathrm{L}$ de acetato de amônia, $6 \mathrm{M}$ (esta etapa não é obrigatória);

10. Acrescentar $300 \mu \mathrm{L}$ de etanol absoluto gelado e agitar lentamente por inversão do tubo. Nesta fase é possível visualizar uma "nuvem" de DNA que se precipita lentamente. Caso tal nuvem não seja visível, colocar a mistura na geladeira $\left(4{ }^{\circ} \mathrm{C}\right)$ por $1 \mathrm{~h}$, pois a baixa temperatura ajuda na precipitação;

11. Centrifugar a $5.000 \mathrm{rpm}$ por $1 \mathrm{~min}$ e inverter o tubo com cuidado para desprezar o sobrenadante;

12. Lavar o pellet de 1 a 3 vezes com etanol $70 \%$ gelado;

13. Desprezar o sobrenadante por inversão do tubo e deixá-lo secar (bomba de vácuo favorece a secagem);

14. Após constatação da ausência de líquido no tubo, acrescentar de 50 a $100 \mu \mathrm{L} \mathrm{de} \mathrm{TE}^{-4}$ (TrisHCl 10mM; EDTA 0,1mM, pH 8,0) para solubilizar o DNA e colocar o tubo em banhomaria a $56^{\circ} \mathrm{C}$ por 15 min e o material já estará pronto para quantificação ou reação de PCR.

\section{3 - Extração de DNA de ossos (antigos ou em pior estado de conservação)}

\section{EXTRAÇÃO DE DNA DE OSSOS (Baseado no "protocolo de Granada")}

1. Serrar/cortar um fragmento de osso (do tamanho de um dente molar, e de preferência onde a espessura do osso seja maior) e limpar todas as superfícies externas do osso com auxílio da lixa;

2. Colocar o osso por, no mínimo, 24 horas no freezer $-80{ }^{\circ} \mathrm{C}$;

3. Moer o osso por \pm 10 segundos no moinho mineralógico, ou pulverizar no Freezer Mill;

4. Separar uma fração preenchendo metade de um tubo de $2 \mathrm{~mL}$ (congelar o restante para caso haja a necessidade de repetir);

5. Colocar $600 \mu \mathrm{L}$ de "tampão de extração", $20 \mu \mathrm{L}$ de Proteinase K $(20 \mathrm{mg} / \mathrm{mL})$ e $25 \mu \mathrm{L}$ de DTT (cuidar para colocar primeiro o tampão, homogeneizar a proteinase $\mathrm{K}$ e depois colocar o DTT);

6. Homogeneizar bem. Incubar $56{ }^{\circ} \mathrm{C}$, por $2 \mathrm{~h}$ e adicionar mais $20 \mu \mathrm{L}$ de Proteinase $\mathrm{K}$. Incubar over night a $56^{\circ} \mathrm{C}$;

7. Colocar $600 \mu \mathrm{L}$ de fenol/clorofórmio/álcool isoamílico 25:24:1 (se necessário, dividir o volume em 2 tubos) e agitar no vortex até a formação de uma emulsão leitosa;

8. Centrifugar por 7 minutos a $10.000 \mathrm{rpm}$;

9. Passar a fase aquosa (sobrenadante) para um novo tubo;

10. Repetir passo 7;

11. Passar a fase aquosa para uma unidade concentradora Microcon 100 contendo $100 \mu \mathrm{L}$ de água ultra pura;

12. Centrifugar a $3.000 \mathrm{rpm}$, até que o volume tenha sido filtrado;

13. Descartar o líquido filtrado e adicionar $500 \mu \mathrm{L}$ de água na membrana;

14. Centrifugar a $3.000 \mathrm{rpm}$ até que todo volume seja filtrado;

15. Repetir passos 13 e 14; 
16. Adicionar $50 \mu \mathrm{L}$ de água estéril (a temperatura ambiente) ou de $\mathrm{TE}^{-4}$ no Microcon e pipetar várias vezes, tendo o cuidado de não romper a membrana;

17. Inverter o Microcon em um tubo novo e centrifugar por 7 min a $5.000 \mathrm{rpm}$;

18. Incubar a $95{ }^{\circ} \mathrm{C}$ por $10 \mathrm{~min}$;

19. DNA extraído, congelar a $-20^{\circ} \mathrm{C}$.

\section{4 - Extração de DNA de dentes (antigos ou em pior estado de conservação)}

\section{EXTRAÇÃO DE DNA DE DENTES ORGÂNICA - molares e pré-molares}

1. Colocar os dentes por, no mínimo, 24 horas no freezer $-80{ }^{\circ} \mathrm{C}$;

2. Moer um dente por \pm 10 segundos no moinho minerológico, aguardar alguns segundos para baixar a poeira ou pulveriza-lo no Freezer Mill;

3. Utilizar para extração uma quantidade aproximada de $0,5 \mathrm{~mL}$ do material. Congelar o restante;

4. Colocar $600 \mu \mathrm{L}$ de "tampão de extração", $24 \mu \mathrm{L}$ de Proteinase K $(20 \mathrm{mg} / \mathrm{mL})$ e $48 \mu \mathrm{L}$ de DTT $1 \mathrm{M}$; cuidar para colocar primeiro o tampão, homogeneizar a proteinase $\mathrm{K}$ e depois colocar o DTT;

5. Incubar a $56{ }^{\circ} \mathrm{C}$, over night $(18-24 \mathrm{~h})$. Colocar mais $24 \mu \mathrm{L}$ de Proteinase $\mathrm{K}$ algumas horas antes de reiniciar a extração;

6. Separar em dois tubos de $2 \mathrm{~mL}$ e colocar igual volume da mistura fenol/clorofórmio/álcool isoamílico 25:24:1;

7. Centrifugar 7 minutos a $10.000 \mathrm{rpm}$;

8. Retirar o sobrenadante e passar para dois novos tubos;

9. Repetir passo 6 e 7;

10. No microcon já com $100 \mu \mathrm{L}$ de $\mathrm{H}_{2} \mathrm{O}$ ultrapura, colocar a fase aquosa da extração;

11. Centrifugar a $3.000 \mathrm{rpm}$, até que o volume tenha sido filtrado;

12. Lavar duas vezes o microcon com $400 \mu \mathrm{L}$ de $\mathrm{H}_{2} \mathrm{O}$ ultrapura ou semelhante, centrifugar a $3.000 \mathrm{rpm}$ até todo o volume ser filtrado;

13. Adicionar $50 \mu \mathrm{L}$ de $\mathrm{TE}^{-4}$ sobre o Microcon e agitar no vortex para recuperar o DNA extraído (OBS: Neste momento troca-se de microtubo e vira-se a membrana concentradora);

14. Recuperar a $5.000 \mathrm{rpm}$, por \pm 5 minutos;

15. Incubar a $95^{\circ} \mathrm{C}$ por $10 \mathrm{~min}$;

16. DNA extraído, congelar a $-20{ }^{\circ} \mathrm{C}$.

\section{5 - Extração diferencial de DNA de amostras provenientes de crimes sexuais (swabs} vaginais, anais e orais) ${ }^{3}$

A- Etapas preliminares para separação das frações FE (Fração Espermatozoide) e FNE (Fração Não-Espermatozoide)

1. Recortar um pedaço do swab e colocá-lo num microtubo de $1,5 \mathrm{~mL}$;

2. Adicionar $500 \mu \mathrm{L}$ de "tampão de extração";

3. Deixar em repouso durante 30 minutos em temperatura ambiente;

4. Adicionar $15 \mu \mathrm{L}$ de Proteinase $\mathrm{K}(10 \mathrm{mg} / \mathrm{mL})$;

5. Agitar no vortex em velocidade baixa para não lisar mecanicamente os espermatozóides;

6. Deixar no banho a $56^{\circ} \mathrm{C}$ durante $1 \mathrm{~h} 30 \mathrm{~min}$;

\footnotetext{
${ }^{3}$ Modificado a partir de: FBI - Federal Bureau of Investigation. PCR-based typing protocols FBI Laboratory. Albuquerque: FBI, 1994.
} 
7. Retirar o algodão com o auxílio de uma pinça, preservando o máximo possível do líquido no interior do tubo;

8. Centrifugar a $10.000 \mathrm{rpm}$ por 1 minuto;

9. Transferir o sobrenadante (contendo o produto de lise das células epiteliais) para outro microtubo identificado como "FNE" e prosseguir com a etapa C;

10. No tubo de onde se retirou o sobrenadante, permaneceram os espermatozóides precipitados. Nomear esta fração como "FE" e prosseguir com a etapa B.

\section{B- Extração de DNA da Fração Espermatozoide}

1. Adicionar $500 \mu \mathrm{L}$ de "tampão de extração" no tubo contendo o precipitado de espermatozóides ("FE");

2. Agitar no vortex em velocidade baixa para não lisar mecanicamente os espermatozoides;

3. Centrifugar a $10.000 \mathrm{rpm}$ por 1 minuto;

4. Descartar o sobrenadante com uma micropipeta, cuidando para não descartar o precipitado;

5. Repetir as etapas anteriores de 1 até 4, somente mais uma vez;

6. Adicionar 500 $\mu \mathrm{L}$ de "tampão de extração";

7. Adicionar $15 \mu \mathrm{L}$ de Proteinase $\mathrm{K}(10 \mathrm{mg} / \mathrm{mL})$;

8. Adicionar $20 \mu \mathrm{L}$ de DTT (ditiotreitol 1M);

9. Agitar as amostras no vortex em velocidade baixa;

10. Deixar no banho a $56^{\circ} \mathrm{C}$ durante $1 \mathrm{~h} 30 \mathrm{~min}$;

11. Adicionar às amostras $500 \mu \mathrm{L}$ da mistura fenol:clorofórmio:álcool isoamílico (25:24:1). Antes da adição, sempre agitar bem a mistura para formar uma solução homogênea. Depois da adição, agitar as amostras no vortex em velocidade baixa até formar uma solução homogênea com aspecto leitoso;

12. Centrifugar a $10.000 \mathrm{rpm}$ por 2 minutos;

13. Separar uma membrana concentradora de DNA (do tipo Microcon) e adicionar $100 \mu \mathrm{L}$ de $\mathrm{TE}^{-4}$ (10mM Tris-HCl, 0,1mM EDTA, $\left.\mathrm{pH} 8,0\right)$ para deixá-la úmida;

14. Transferir cuidadosamente $400 \mu \mathrm{L}$ da fase aquosa para as unidades concentradoras Microcon;

15. Centrifugar a $5.000 \mathrm{rpm}$ por 15 minutos;

16. Desprezar o filtrado;

17. Adicionar $400 \mu \mathrm{L}$ de $\mathrm{TE}^{-4}$ ou água estéril à unidade concentradora do Microcon;

18. Centrifugar a $5.000 \mathrm{rpm}$ por 15 minutos;

19. Adicionar $50 \mu \mathrm{L}_{\text {de }} \mathrm{TE}^{-4}$ ou água estéril à unidade concentradora do Microcon;

20. Para recolher o DNA extraído, remover o concentrador do tubo que contém o filtrado (a ser desprezado) e cuidadosamente inverter a unidade concentradora Microcon (contendo $50 \mu \mathrm{L} \mathrm{de}^{-4}$ ) em um novo microtubo previamente identificado;

21. Centrifugar a 5.000 rpm por 5 minutos;

22. Desprezar a unidade concentradora;

22. Se a amostra não for encaminhada para amplificação, conservar o DNA em geladeira ou no freezer.

C- Extração de DNA da Fração Não-Espermatozoide (seguir esta etapa com a fração "FNE", $\underline{\text { tubo contendo o produto de lise das células epiteliais da etapa A) }}$

1. Adicionar às amostras $500 \mu \mathrm{L}$ da mistura fenol:clorofórmio:álcool isoamílico (25:24:1). Antes da adição, sempre agitar bem a mistura para formar uma solução homogênea.

2. Depois da adição, agitar as amostras no vortex em velocidade baixa até formar uma solução homogênea com aspecto leitoso; 
3. Centrifugar a 10.000 rpm por 2 minutos;

4. Caso o sobrenadante não esteja límpido, repetir as etapas 2 e 3 uma ou duas vezes;

5. Transferir o sobrenadante (fase aquosa) com a micropipeta (com cuidado para não abalar a fina interfase formada) para um novo microtubo de $1,5 \mathrm{~mL}$, identificado como "FNE";

6. Adicionar $300 \mu \mathrm{L}$ de Etanol absoluto gelado e agitar lentamente por inversão do tubo. Em alguns casos observa-se uma "nuvem" correspondente à precipitação do DNA;

7. Centrifugar a $10.000 \mathrm{rpm}$ por 2 minutos;

8. Desprezar o sobrenadante invertendo o tubo com cuidado;

9. Adicionar $300 \mu \mathrm{L}$ de Etanol $70 \%$ gelado;

10. Centrifugar a 10.000 rpm por 2 minutos;

11. Desprezar o sobrenadante invertendo o tubo com cuidado;

12. Repetir as operações de 9 a 11 mais duas vezes;

13. Deixar os tubos secando em temperatura ambiente, invertidos e apoiados sobre um papel absorvente;

14. Após evaporação total do líquido, acrescentar $50 \mu \mathrm{L}$ de $\mathrm{TE}^{-4}$ para ressuspender o DNA;

15. Deixar no banho a $56^{\circ} \mathrm{C}$ durante 15 minutos;

16. Se a amostra não for encaminhada para amplificação, conservar o DNA em geladeira ou no freezer.

\section{6 - Extração de DNA de manchas de sangue e sêmen utilizando kit comercial contendo resina magnética DNA IQ ${ }^{T M}$ System (Promega Corporation - Cat. \# DC6700)}

Preparo prévio:

1. Tampão de Lavagem 1x (Wash Buffer 1x - a composição detalhada do tampão não é informada pelo fabricante do reagente)

No kit para 400 amostras, quando da abertura de uma nova caixa, acrescentar $35 \mathrm{~mL}$ de Etanol 95 a 100\% e 35mL de álcool isopropílico ao tampão de lavagem 2x, de modo que se obtenha no final o tampão de lavagem 1x;

Homogeneizar por inversão inúmeras vezes e identificar o frasco como tampão de lavagem $1 \mathrm{x}$.

2. Ajustar a temperatura do bloco de aquecimento para $95^{\circ} \mathrm{C}$;

3. Tampão de Lise (Lysis Buffer - a composição detalhada do tampão não é informada pelo fabricante do reagente) - preparar a quantidade total necessária de tampão de lise a ser utilizada nas duas etapas da extração e para todas as amostras, de acordo com a tabela abaixo:

\begin{tabular}{|c|c|c|c|}
\hline Tipo de amostra & Vol. da $1^{\text {a }}$. etapa & Vol. da $2^{a}$. etapa & Vol. total \\
\hline Sangue líquido & $100 \mu \mathrm{L}$ & $100 \mu \mathrm{L}$ & $200 \mu \mathrm{L}$ \\
\hline Swab de algodão & $250 \mu \mathrm{L}$ & $100 \mu \mathrm{L}$ & $350 \mu \mathrm{L}$ \\
\hline Papel FTA $^{\circledR}$ & $150 \mu \mathrm{L}$ & $100 \mu \mathrm{L}$ & $250 \mu \mathrm{L}$ \\
\hline Pedaço de tecido (até $25 \mathrm{~mm}^{2}$ ) & $150 \mu \mathrm{L}$ & $100 \mu \mathrm{L}$ & $250 \mu \mathrm{L}$ \\
\hline
\end{tabular}

Para cada $100 \mu \mathrm{L}$ de tampão de lise requerido, adicionar $1 \mu \mathrm{L}$ de DTT. Homogeneizar por inversão inúmeras vezes. Identificar o tubo como "tampão de lise".

4. Ajustar o vortex para a rotação máxima

Procedimento para extração de manchas de sangue e sêmen:

1. Colocar a amostra num microtubo de $1,5 \mathrm{~mL}$; 
2. Adicionar a quantidade adequada de tampão de lise preparado requerida na primeira etapa (vide tabela acima). Fechar a tampa e incubar a $95{ }^{\circ} \mathrm{C}$ por 30 minutos (se o tecido for sensível ao calor, incubar em temperatura ambiente);

3. Remover o tubo do aquecimento e diminuir a temperatura do bloco para $65^{\circ} \mathrm{C}$. Transferir o tampão de lise e a amostra para um microtubo de $200 \mu \mathrm{L}$ contendo um pequeno furo no seu fundo;

4. Colocar este tubo no interior de outro microtubo de $1,5 \mathrm{~mL}$ e centrifugar por 2 minutos na rotação máxima. Após a centrifugação, descartar o tubo pequeno onde permaneceu o pedaço de tecido;

5. Acrescentar $7 \mu \mathrm{L}$ da resina magnética que acompanha o kit (agitá-la no vortex por 10 segundos antes de acresecentar);

6. Levar ao vortex por 3 segundos e incubar em temperatura ambiente por 5 minutos (no máximo 10 minutos);

7. Levar ao vortex por 2 segundos e colocar o tubo na estante magnética. A separação da resina magnética ocorrerá instantaneamente;

8. Cuidadosamente remover todo o líquido com micropipeta, sem encostar a ponteira na resina magnética;

9. Adicionar $100 \mu \mathrm{L}$ do tampão de lise preparado, remover o tubo da estante e levar ao vortex por 2 segundos;

10. Retornar o tubo à estante e descartar todo o tampão de lise;

11. Adicionar $100 \mu \mathrm{L}$ do tampão de lavagem 1x. Remover o tubo da estante magnética e levar ao vortex por 2 segundos;

12. Retornar o tubo à estante magnética e descartar o tampão de lavagem;

13. Repetir os passos 11 e 12 por mais duas vezes, resultando num total de três lavagens. Certificar-se de que toda a solução tenha sido removida ao final da última lavagem;

14. Com a tampa aberta, deixar o restante do tampão de lavagem evaporar por 5 minutos (no máximo 15 minutos);

15. Adicionar de 25 a $100 \mu \mathrm{L}$ (geralmente $40 \mu \mathrm{L}$ ) de tampão de eluição (cuja composição detalhada também não é informada pelo fabricante do kit), dependendo da quantidade de material biológico utilizada. Volumes de eluição menores garantem uma concentração final de DNA mais elevada;

16. Fechar a tampa, levar o tubo ao vortex por 2 segundos e incubar a $65^{\circ} \mathrm{C}$ por 5 minutos;

17. Remover o tubo do bloco de aquecimento e levar ao vortex por 2 segundos. Imediatamente colocá-lo na estante magnética;

18. Transferir a solução que contém o DNA para outro microtubo;

19. A solução poderá ser estocada a $4{ }^{\circ} \mathrm{C}$ por alguns dias ou de -20 a $-70{ }^{\circ} \mathrm{C}$ por tempos mais prolongados. 